\title{
hydrology OF the albeMarle-PAMLICO REgION
}

no. $75-9$

A prellimimary 『egporis on the

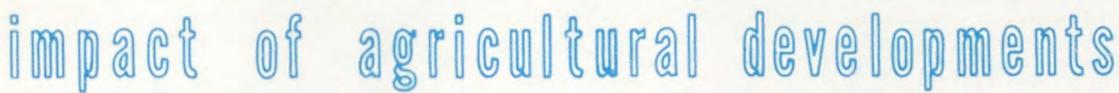

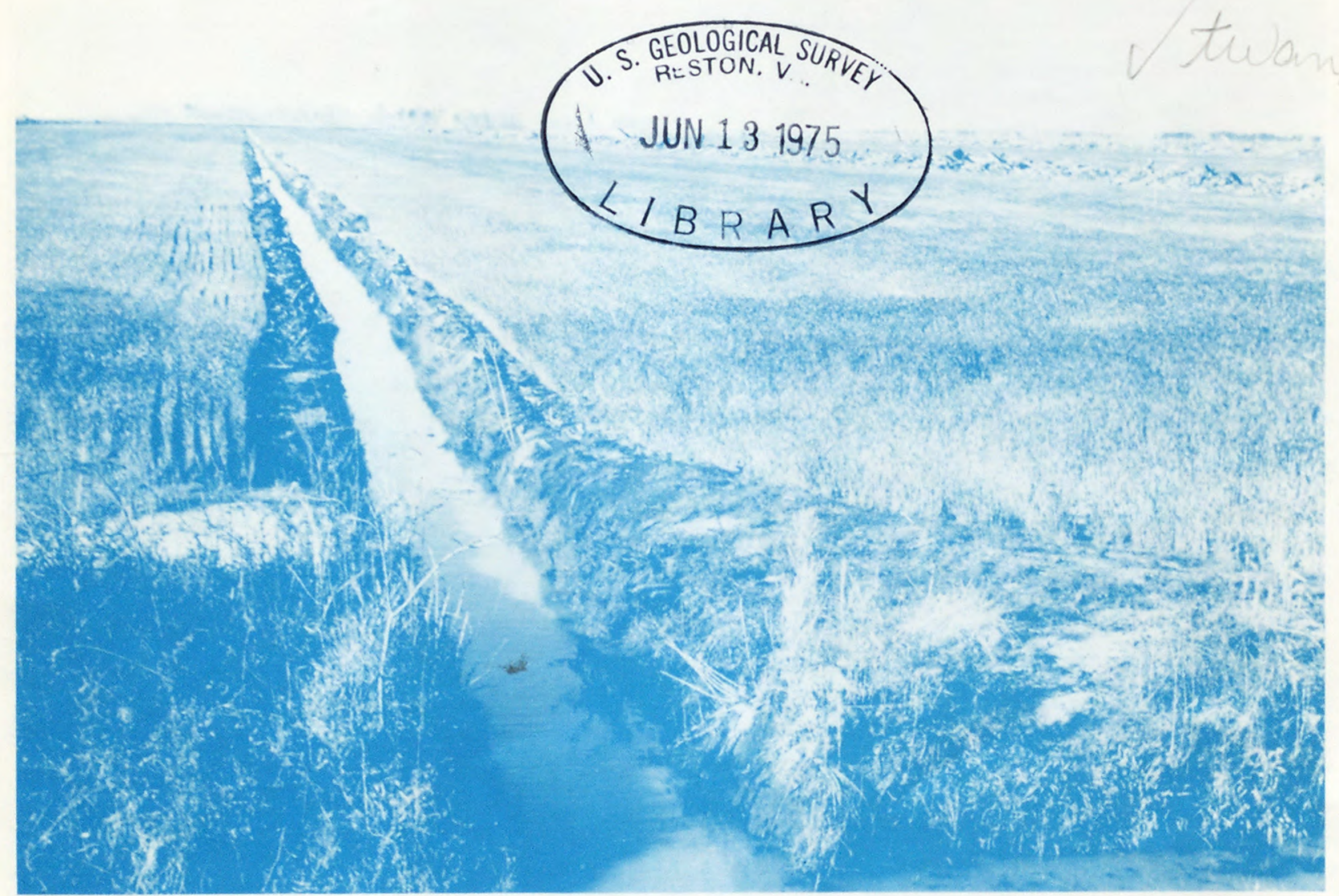

U S GEOLOGDGAL SORVEY

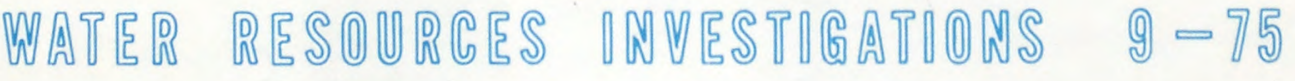

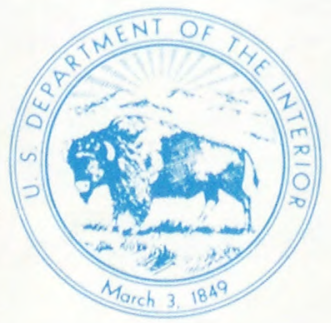

PREPARED IN COOPERATION WITH THE

NORTH CAROLINA DEPARTMENT OF NATURAL

AND ECONOMIC RESOURCES 


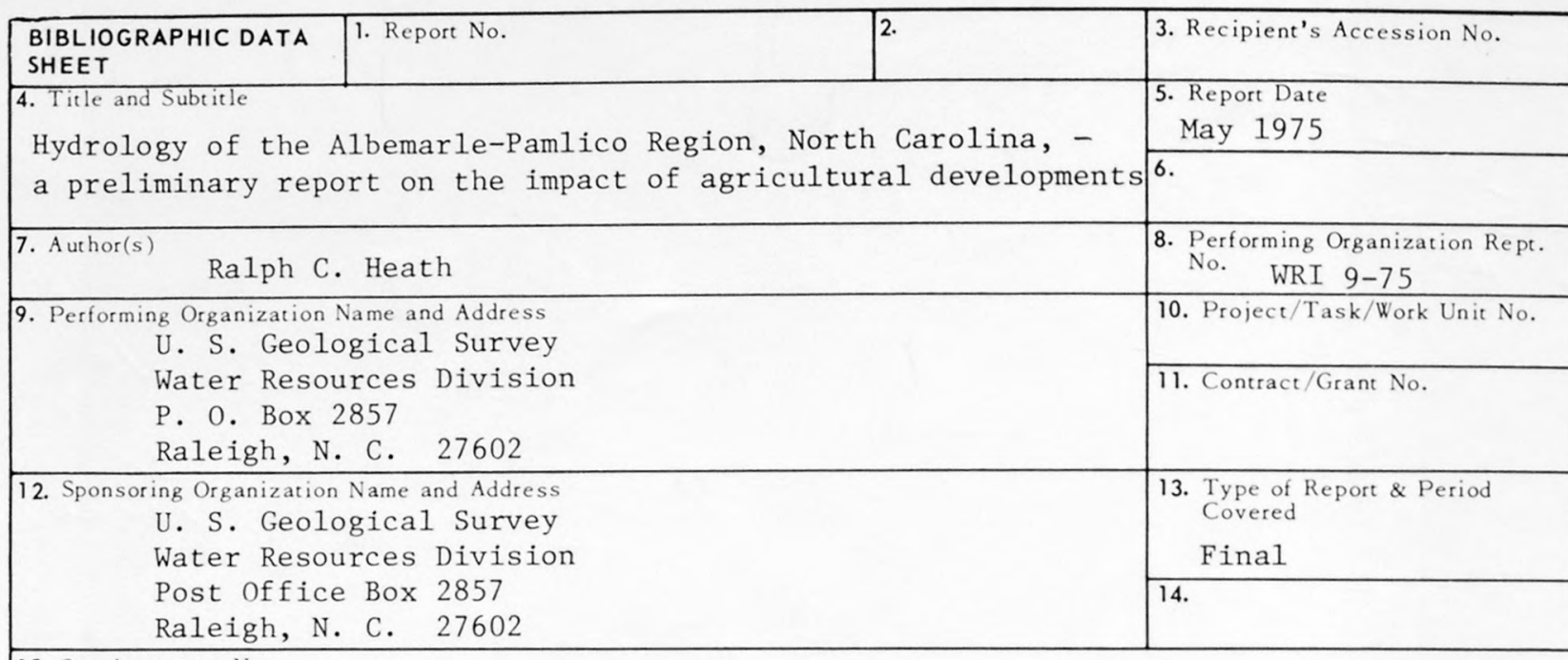

15. Supplementary Notes

Prepared in cooperation with the North Carolina Department of

Natural and Economic Resources

16. Abstracts Extensive agricultural land clearing and drainage operations underway in a 650 square mile part of the Albemarle-Pamlico region--a 1,634 square mile peninsula in North Carolina lying between Albemarle Sound on the North and the Pamlico River on the south--are changing the hydrology of the area.

The artificial drainage system being constructed in the region, although it will probably result in only a slight modification of the natural annual evapotranspiration, overland runoff, and ground-water discharge, will likely result in several important problems.

First, changes in the water quality of the sounds and estuaries resulting from the rapid runoff of storm waters may prove harmful to the fishery resources. Second, lowering of the water table may cause relatively rapid subsidence of the land surface in an irregular pattern in the extensive areas underlain by thick peat deposits as a result of biochemical oxidation, peat fires, and wind.

17. Key Words and Document Analysis. 17a. Descriptors

*Swamps, *Drainage practices, *Land clearing, *Peat, Hydrology, Precipitation, Ground water, Surface water, Evapotranspiration, Farm management, Wells, Shrimp, Oysters, North Carolina, Channelization.

17b. Identifiers/Open-Ended Terms

*Lake Phelps, *Lake Mattamuskeet, *Hyde County, *Tyrrel1 County, *Dare County, *Washington County, *Quaternary, *Yorktown Formation, *Castle Hayne Limestone, *Dismal Swamp, Albemarle Sound, Pam1ico River, New Lake, Pungo Lake, Corporate Farms, Pungo River Formation, Suffolk Scarp.

17c. COSATI Field/Group

18. Availability Statement

No restriction on distribution 
No. $9-75$

\section{HYDROLOGY OF THE ALBEMARLE-PAMLICO REGION NORTH CAROLINA}

A PRELIMINARY REPORT ON THE

IMPACT OF AGRICULTURAL DEVELOPMENTS

BY

Ralph C. Heath

\section{$\checkmark$ \\ U. S. GEOLOGICAL SURVEY [water Resources Dinision ] WATER-Resources InVEstigations 9-75}

Prepared in cooperation with the North Carolina Department of Natural and Economic Resources 


\section{UNITED STATES DEPARTMENT OF THE INTERIOR \\ Rogers C. B. Morton, Secretary}

GEOLOGICAL SURVEY

V. E. McKelvey, Director

For Additional Information Write to:

U. S. GEOLOGICAL SURVEY

POST OFFICE BOX 2857

RaLEIGH, INORTH CaRolina 27602

$$
\text { MaY } 1975
$$




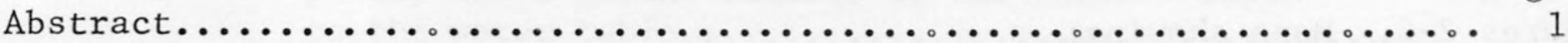

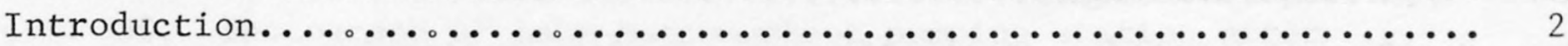

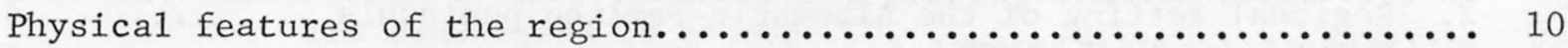

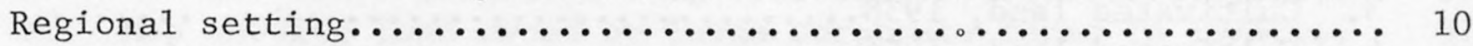

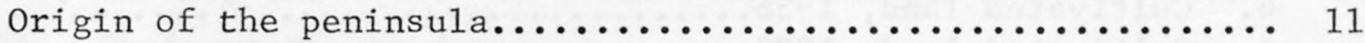

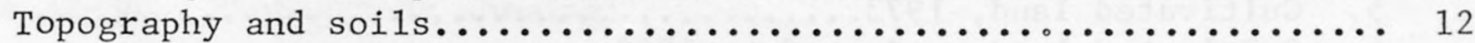

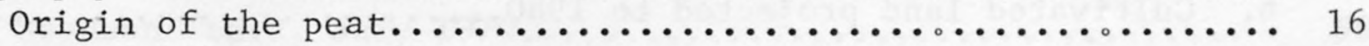

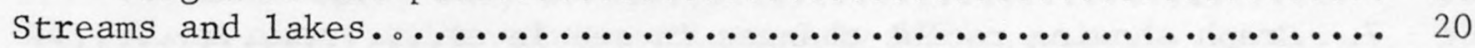

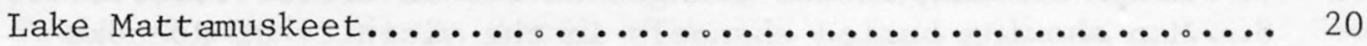

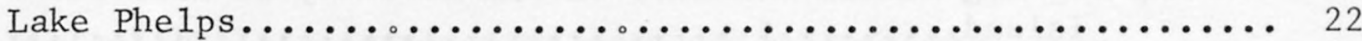

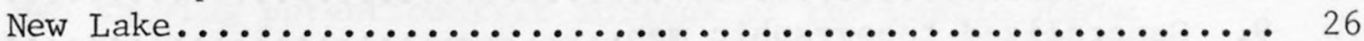

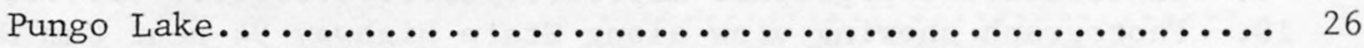

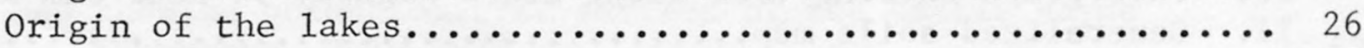

Geology of the region........................... 28

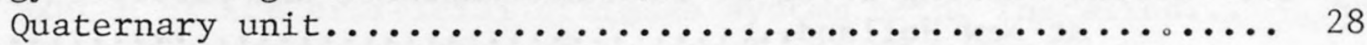

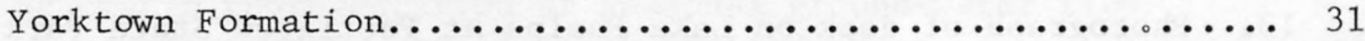

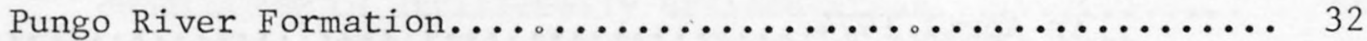

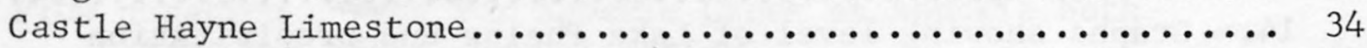

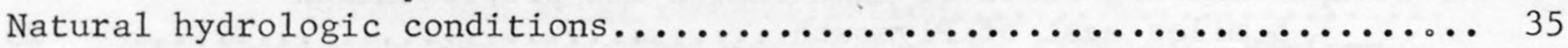

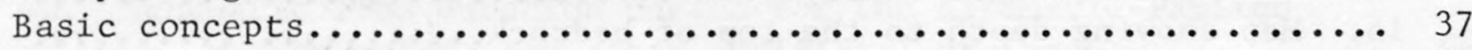

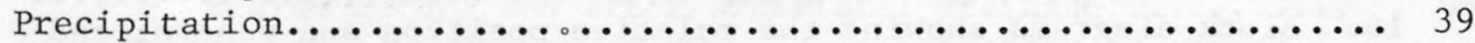

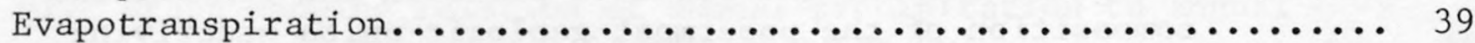

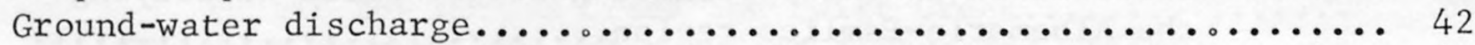

Fresh water-sea water relationship................. 45

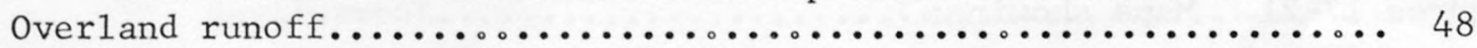

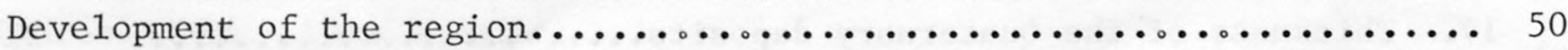

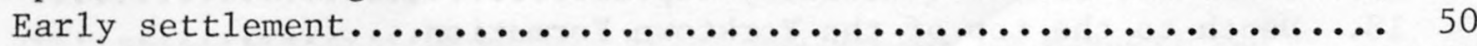

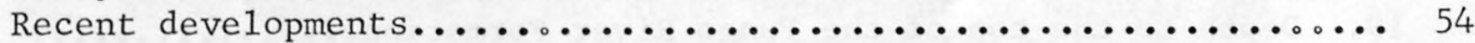

Lake Mattamuskeet development...................... 54

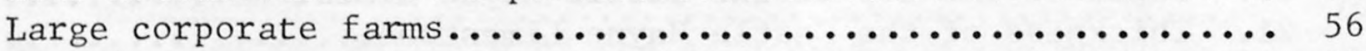

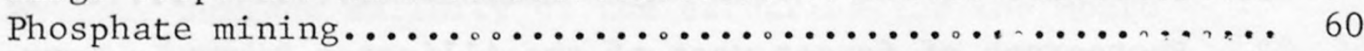

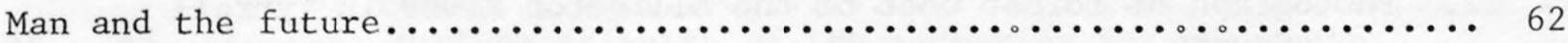

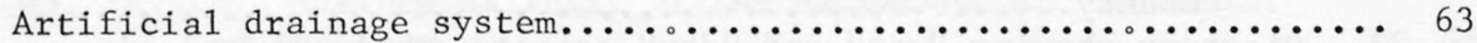

Effect of artificial drainage on hydrology................. 64

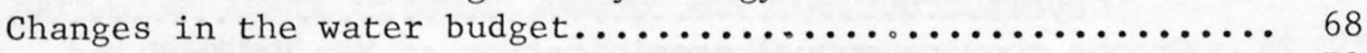

Problems related to the agricultural developments............ 71

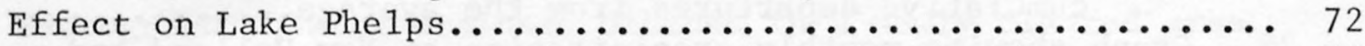

Effect on water quality of the sounds and estuaries....... 75

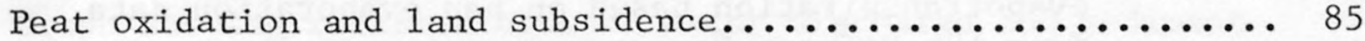

Effect on ground-water conditions................. 88

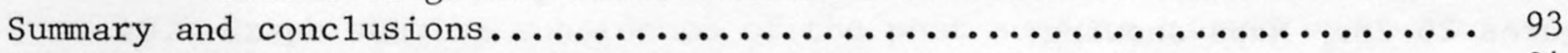

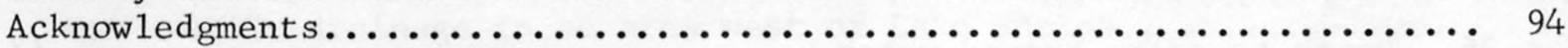

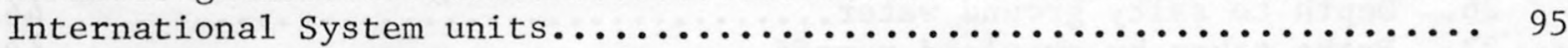

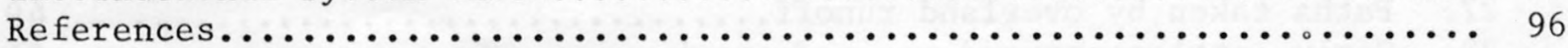


Figure 1. Photograph of First Colony Farms near Lake Phelps, Washington

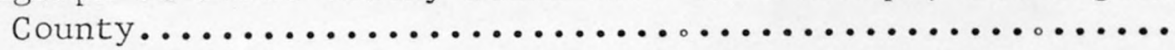

Figures 2-6. Maps showing:

2. Regional setting of the Albemarle-Pamlico peninsula........

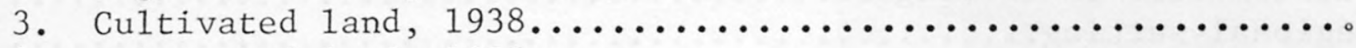

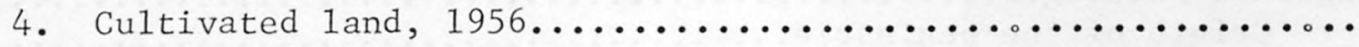

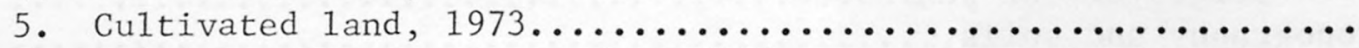

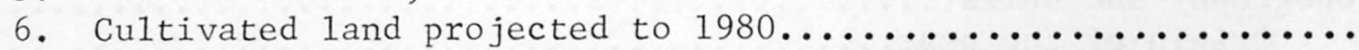

7. Graph showing recent changes in sea leve1...............

8. Map showing buried channels in the vicinity of Roanoke

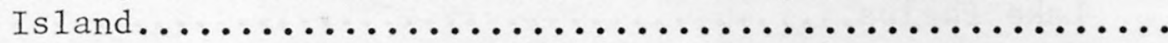

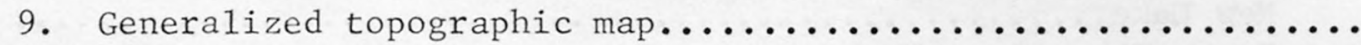

10. Photograph showing view along State Highway 94 near Gum Neck.

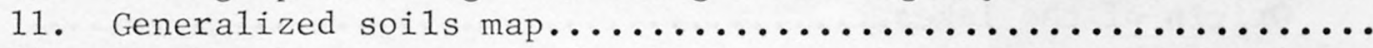

12. Graphs showing level of Laka Mattamuskeet and precipitation

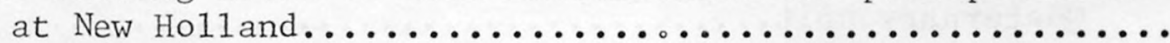

13. Photograph of dock on Lake Phelps at Pettigrew State Park

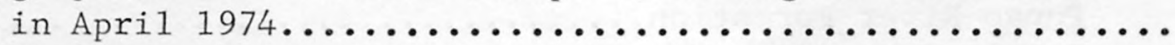

14. Graphs showing level of Lake Phelps and precipitation

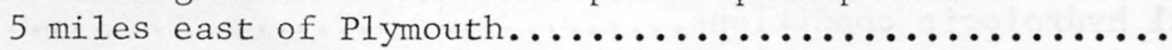

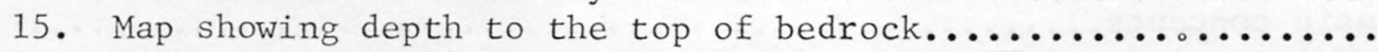

16. Block diagrams showing the relative position and generalized composition of the uppermost geologic units underlying the Albemarle-Pamlico region...................

Figures 17-21. Maps showing:

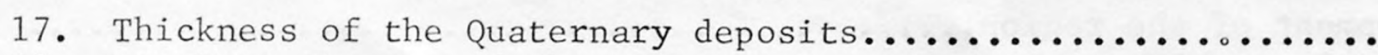

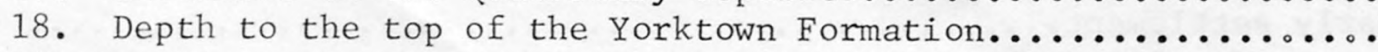

19. Depth to the top of the Pungo River Formation.............

20. Depth to the top of the Castle Hayne Limestone.............

21. Thickness of the Castle Hayne Limestone.................

22. Photograph of forest west of the Alligator River in Tyrrell

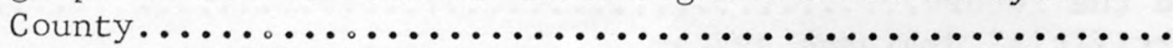

23. Diagrams showing "wet" and "dry" aspects of the hydrologic

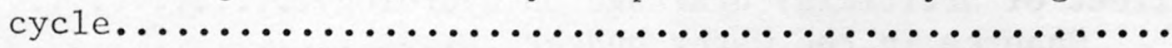

24. Graphs showing annul precipitation at New Holland and cumulative departures from the average..............

25. Graph showing monthly precipitation at New Holland and evapotranspiration based on pan evaporation data

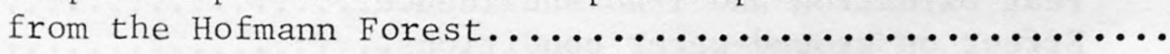

Figures 26-28. Maps showing:

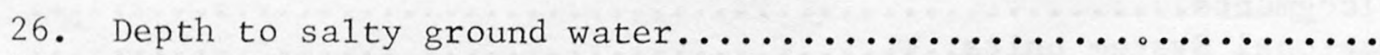

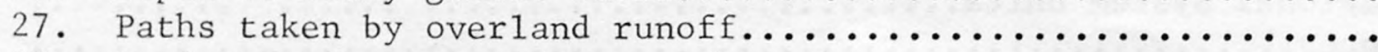

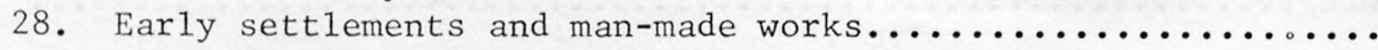


CONTENTS

Figure 29. Photograph of graves in the Gum Neck community placed

partly above ground because of the shallow depth

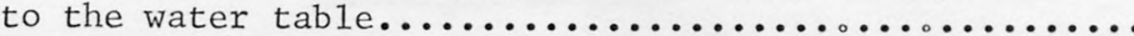

30. Photograph of Lake Mattamuskeet pumping station after

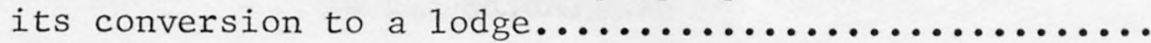

31. Map showing 1 and owned by large corporate farms in $1974 \ldots .$.

Figures 32-34. Photographs showing:

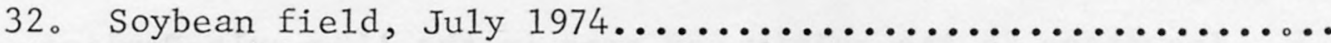

33. Field ditch under construction, July $1974 \ldots \ldots \ldots \ldots \ldots \ldots \ldots \ldots$

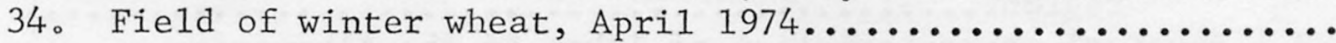

35. Map showing potentiometric surface of the Castle Hayne

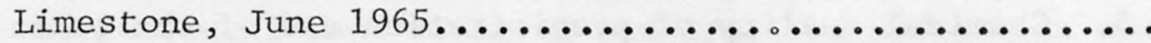

36. Map showing potentiometric surface of the Castle Hayne

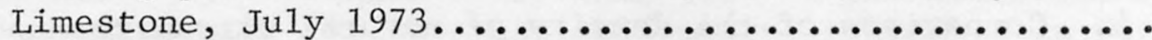

37. Sketch of the artificial drainage system being installed...

38. Schematic representation of seasonal ground-water flow conditions in artificially drained areas............

39. Flow duration curves for Ahoskie Creek at Ahoskie both

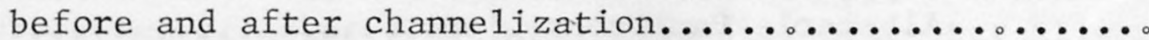

40. Schematic flow duration curves for the Albemarle-Pamlico region before and after artificial drainage..........

41. Graph showing relation of annual precipitation to annual runoff for Durham Creek and Swift Creek..............

42. Diagrams showing the water budget before and after

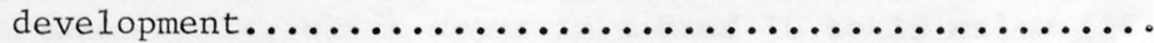

Figures 43-46. Maps showing:

43. Areas determined by the State Department of Natural and Economic Resources to be important for seafood

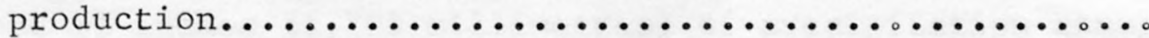

44. Average surface salinity of the estuaries for the month

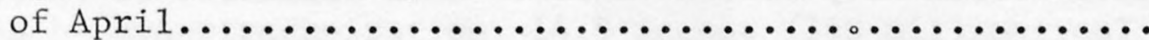

45. Average surface salinity of the estuaries for the month

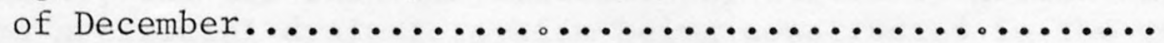

46. Estuarine areas in which oyster and clam harvesting is

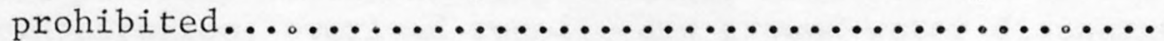

47. Photograph showing drainage ditches in a newly cleared area

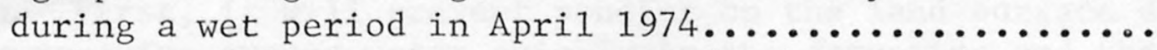

48. Graph showing relation between water discharge and sediment for Creeping Swamp near Vanceboro.................

49. Graph showing subsidence of the peat surface caused by drainage in an area west of Lake Phelps............. 


\section{TABLES}

Table 1. Increases in the cultivated area in the Albemarle-Pamlico

2. Physical characteristics of lakes in the Albemarle-

Pamlico region............................ 20

3. Chemical quality of precipitation and of the lakes in the

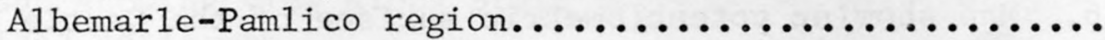

4. Comparison of the density of natural stream channels and

the artificial drainage system in the Albemarle-

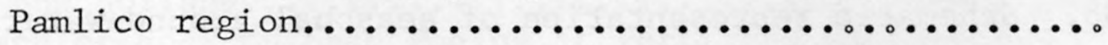

5. Water-quality data collected by the North Carolina

Department of Natural and Economic Resources in the

Albemarle-Pamlico region.......................

6. Factors for converting English units to International

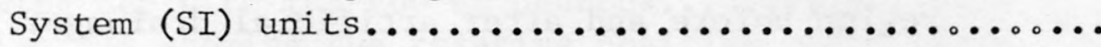


HYDROLOGY OF THE ALBEMARLE-PAMLICO REGION, NORTH CAROLINA

A preliminary report on the impact of agricultural developments

By Ralph C. Heath

ABSTRACT

Extensive agricultural land clearing and drainage operations underway in a 650-square-mile (1,684-square-kilometre) part of the Albemarle-Pamlico region--a 1,634-square-mile (4,232-square-kilometre) peninsula in North Carolina lying between Albemarle Sound on the north and the Pamlico River on the south--are changing the hydrology of the area.

Under natural conditions, the entire area is swampy, with 1 and slopes ranging from a maximum of about 5 feet per mile ( 1.0 metre per kilometre) to a minimum of less than 1 foot per mile (0.2 metre per kilometre). About two-thirds of the area, including most of the eastern half, is less than 5 feet ( 1.5 metres) above sea leve1. Two major soil types are found in the area, "mineral" soils consisting of varying mixtures of sand, silt, and clay, and organic soils consisting of fragments of trees, shrubs, and other plants. The organic soils, which occur in a band 10 to 15 miles (16 to 24 kilometres) wide through the central part of the region, is as much as 12 feet (3.7 metres) thick and is highly prized for farming.

The hydrology of the region is not well known. The area receives an average of about 51 inches (1,295 millimetres) of precipitation annually. of this amount, it is estimated that about 36 inches ( 914 millimetres) leaves the area by evapotranspiration, 14.5 inches (368 millimetres) leaves by overland runoff, and 0.5 inch (13 millimetres) leaves by ground-water discharge. The artificial drainage system being constructed in the region, although it will probably result in only a slight modification of the annual evapotranspiration, overland runoff, and ground-water discharge, will produce two hydrologic effects that may have far-reaching consequences for the region. First, it will prevent ponding on the land surface during heavy rains by removing excess water quickly to the estuaries and the coast. Second, seepage of ground water into the artificial channels will lower ground-water levels from an average position of about 1 foot ( 0.3 metre) below land surface to an average position of about 4 feet (1.2 metres) below 1 and surface. 
From this combination of circumstances, several important problems seem likely to result. First, changes in the water quality of the sounds and estuaries caused by rapid runoff of storm waters may be harmful to the fishery resources. Secondly, lowering of the water table may cause substantial subsidence of the land surface in an irregular pattern in the extensive areas underlain by thick peat deposits as a result of biochemical oxidation, peat fires, and wind. Thirdly, salt-water encroachment both in shallow and in deep aquifers may accelerate as a result of land drainage and increased withdrawals of ground water for irrigation and other uses.

Although none of these problems can be completely avoided, some of their adverse effects can be significantly reduced by the application of sound management policies based on water-resources technology now available.

\section{INTRODUCTION}

The extensive agricultural developments now underway on the outer Coastal Plain first received widespread publicity in the Sunday edition of the Raleigh News and Observer for May 12, 1974. The article, headlined "Massive East N。C.Farm Stirs Hopes and Fears," noted that a 600-mile farm was being carved out of the swampy wilderness of four economically distressed eastern North Carolina counties (fig. 1).

Plans for the conversion of large areas in Dare, Hyde, Tyrrell, and Washington Counties from swamps to farmland, even though known by State officials to be economically beneficial, caused concern about possible damage to the environment. As a first step in assessing the environmental impact, Mr. James Harrington, Secretary, Department of Natural and Economic Resources, requested the U. S. Geological Survey to undertake a study of and to prepare a report on the effect of the 1 and clearing and associated drainage channels on the water resources of the area. Because of the need to identify potential problems as quickly as possible, the study was to be based on existing and readily available information. This report contains the results of the study.

The area of concern in this report is the peninsula lying between Albemarle Sound on the north and the Pamlico River on the south (fig. 2). It includes the mainland part of Dare County, and al1 of Hyde, Tyrre11, and Washington Counties. This is the area in which the major 1 and clearing and drainage operations are underway. A large area of land known as Open Grounds Farms, is also being cleared and drained in Carteret County, north of Beaufort, but that area is not included in this report. 


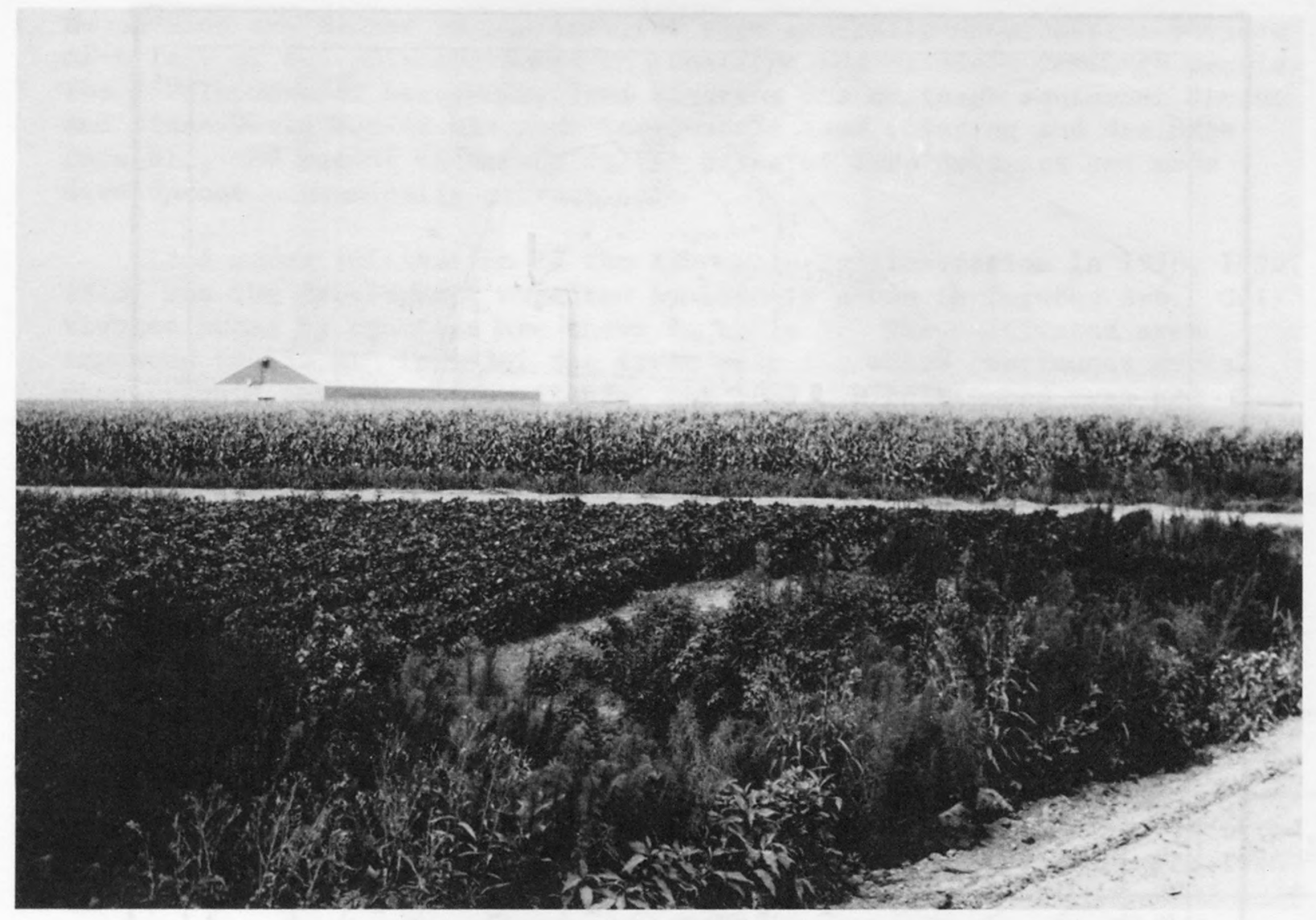

Figure 1.--First Colony Farms near Lake Phelps, Washington County.

The area in the Albemarle-Pamlico region for which land-clearing and drainage plans were being developed in 1974 encompasses about 414,000 acres or nearly $650 \mathrm{mi}^{2}$. This is 40 percent of the $1,634 \mathrm{mi}^{2}$ of 1 and area in the region. However, not all of this area will be cleared. Between 100,000 and 150,000 acres will be left in its natural state to serye as a buffer zone between the coastal waters and the farming operations. -

1/ Since this report was prepared for printing, the preliminary plans deve1oped during the summer of 1974, on which the report is based, have been modified on the basis of experience during the winter of 1974-75. Present plans are to avoid development of the areas underlain by thick organic soils and to substantially reduce the rate at which 1 and is cleared and drained. Consequently, the areas predicted to be cleared by 1980 may be too large.

The developments now underway in the Albemarle-Pamlico region are the culmination of efforts which began when the first settlers arrived in the area about 1700. These settlers developed farms on the higher and better d-ained lands bordering Albemarle Sound and the Pamlico River. Attempts 


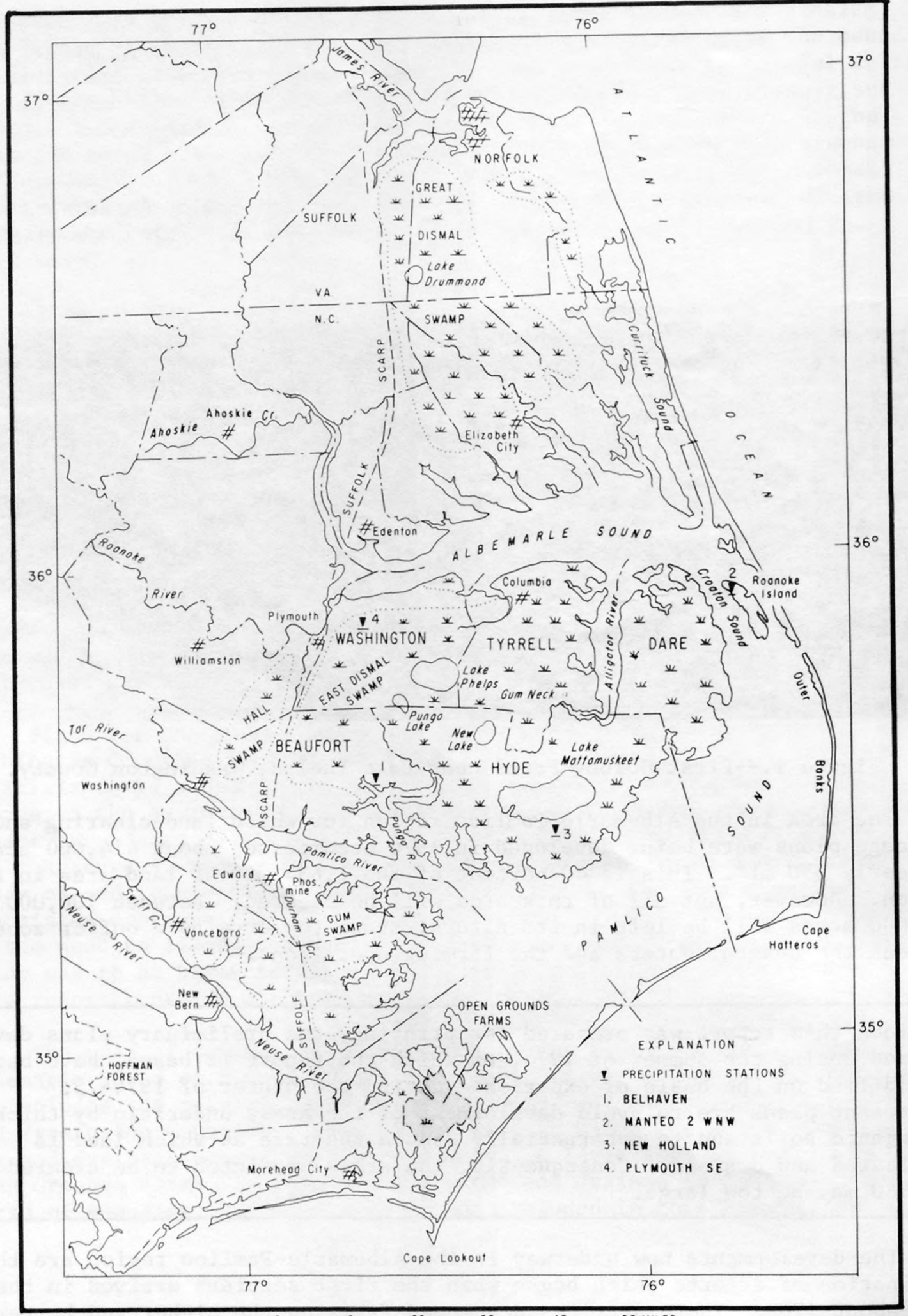

Figure 2.--Regional setting of the Albemarle-Pamlico peninsula. 
to develop the swamps in the interior were generally unsuccessful because of a lack of suitable equipment to construct and maintain drainage canals. The development of heavy-duty land clearing and drainage equipment during and since World War II has made large-scale land clearing and drainage feasible, and recent increases in the price of farm products has made developinent economically attractive.

Land under cultivation in the Albemarle-Pamlico region in 1938, 1956, 1973, and the development expected by 1980 is shown in figures 3-6. Cu1tivated areas by cqunties are shown in table 1 . The cultivated area amounted to $156 \mathrm{mi}^{2}$ in 1938, the first year for which continuous aerial photographic coverage is available. By 1973 the cultivated area had increased to $420 \mathrm{mi}^{2}$ and is expected, on the basis of preliminary plans of the larger corporate farms, to increase to $828 \mathrm{mi}^{2}$ by 1980 . Clearing by land owners, whose plans are not known at this time, will doubtless increase the cultivated area to at least $1,000 \mathrm{mi}^{2}$ by 1980 or to more than 60 percent of the area.

Table 1.--Increases in the cultivated area in the Albemarle-Pamlico region

\begin{tabular}{|c|c|c|c|c|c|}
\hline \multirow[b]{2}{*}{ County } & \multirow[b]{2}{*}{$\begin{array}{l}\text { Total land } \\
\text { area }\left(\mathrm{mi}^{2}\right)\end{array}$} & \multicolumn{4}{|c|}{ Land under cultivation $\left(\mathrm{mi}^{2}\right)$} \\
\hline & & $\begin{array}{r}1938- \\
1939\end{array}$ & $\begin{array}{r}1956- \\
1959\end{array}$ & 1973 & $\begin{array}{l}\text { Predicted } \\
\quad \text { to } 1980 \text { - }\end{array}$ \\
\hline Dare & 288 ㄴ & $3 \underline{2 /}$ & 3 & $4 \underline{21}$ & 187 \\
\hline Hyde & 613 & 65 & 71 & 199 & 251 \\
\hline Tyrre11 & 390 & 28 & 36 & 61 & 204 \\
\hline Washington & 343 & 60 & 85 & 156 & 186 \\
\hline Totals & 1,634 & 156 & 195 & 420 & 828 \\
\hline
\end{tabular}

$\frac{1 /}{2 /}$ Mainland part only

$\frac{2}{3}$ Estimates

Based on preliminary plans of larger corporate farms.

The conversion of swamps to intensive farming operations requires profound changes in the landscape. Vegetation, which in the AlbemarlePamlico region consists of second or third growth trees and shrubs, is uprooted and burned. Drainage ditches and canals are dug to remove excess water. This lowers ground-water levels, and increases the rate of runoff from the area. What is the impact of these changes on ground-water supplies and on the streams and sounds which receive the runoff? How will 


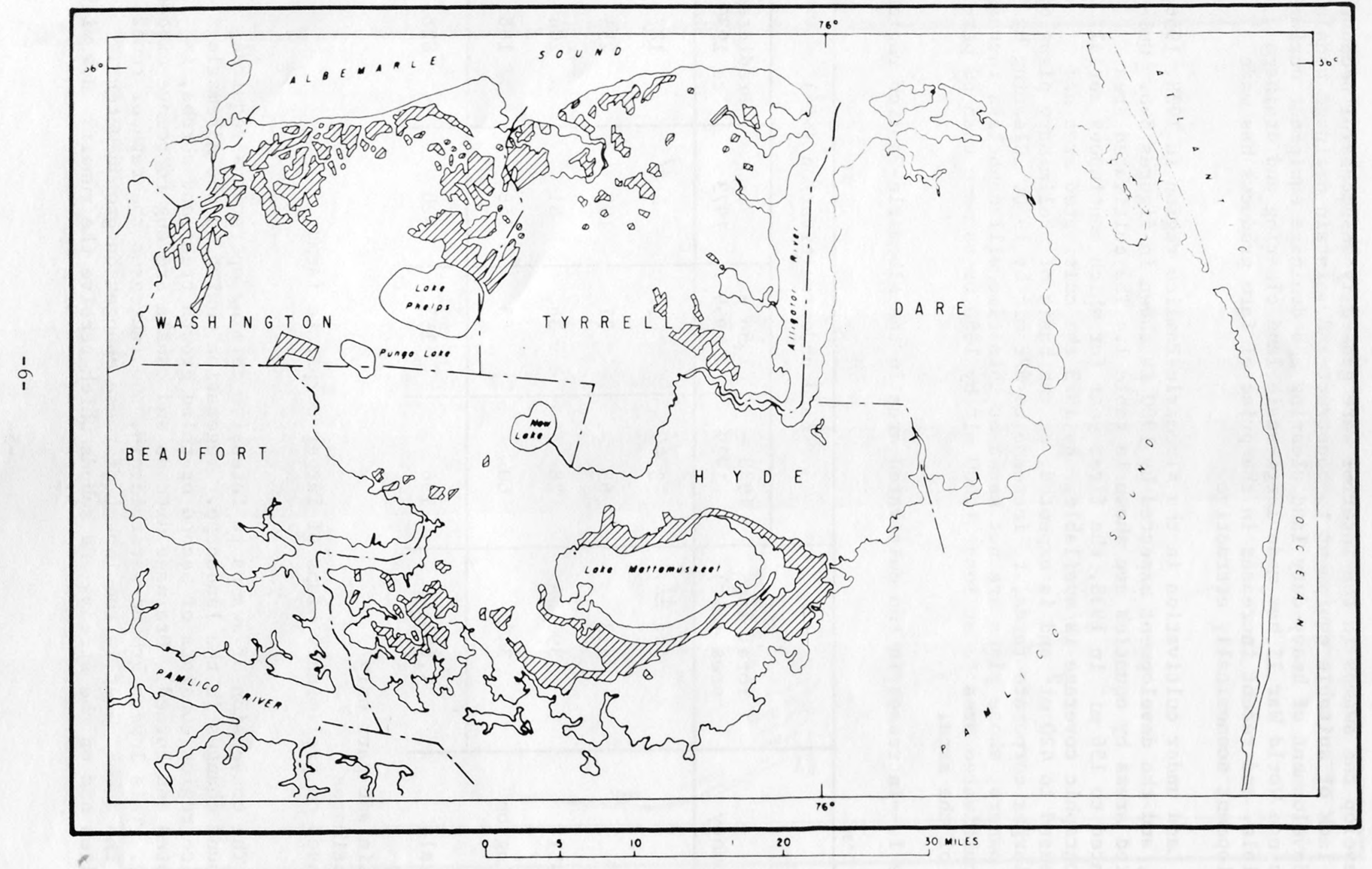

Figure 3.--Cultivated 1and, 1938. 


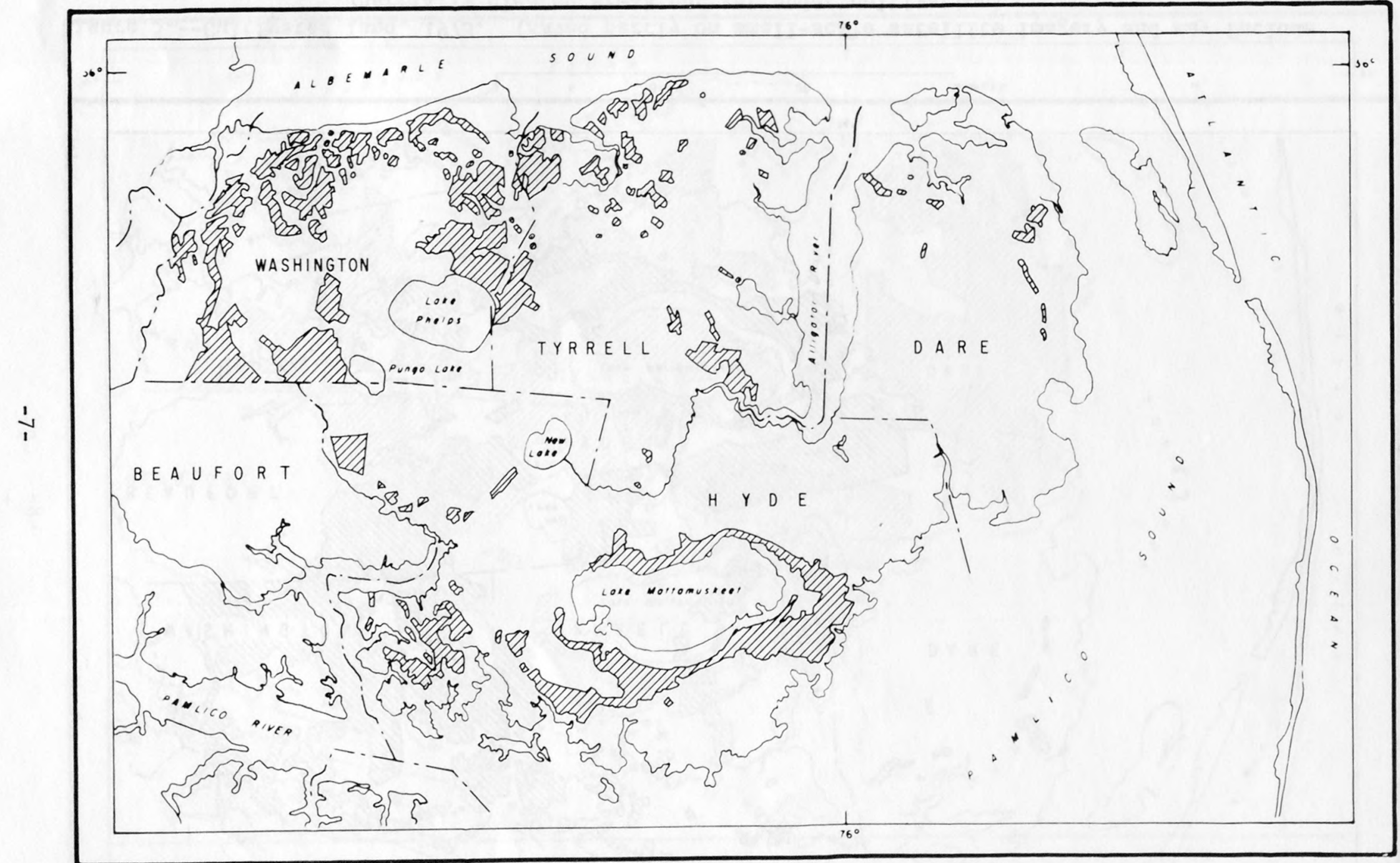

Figure 4.--Cultivated 1and, 1956. 


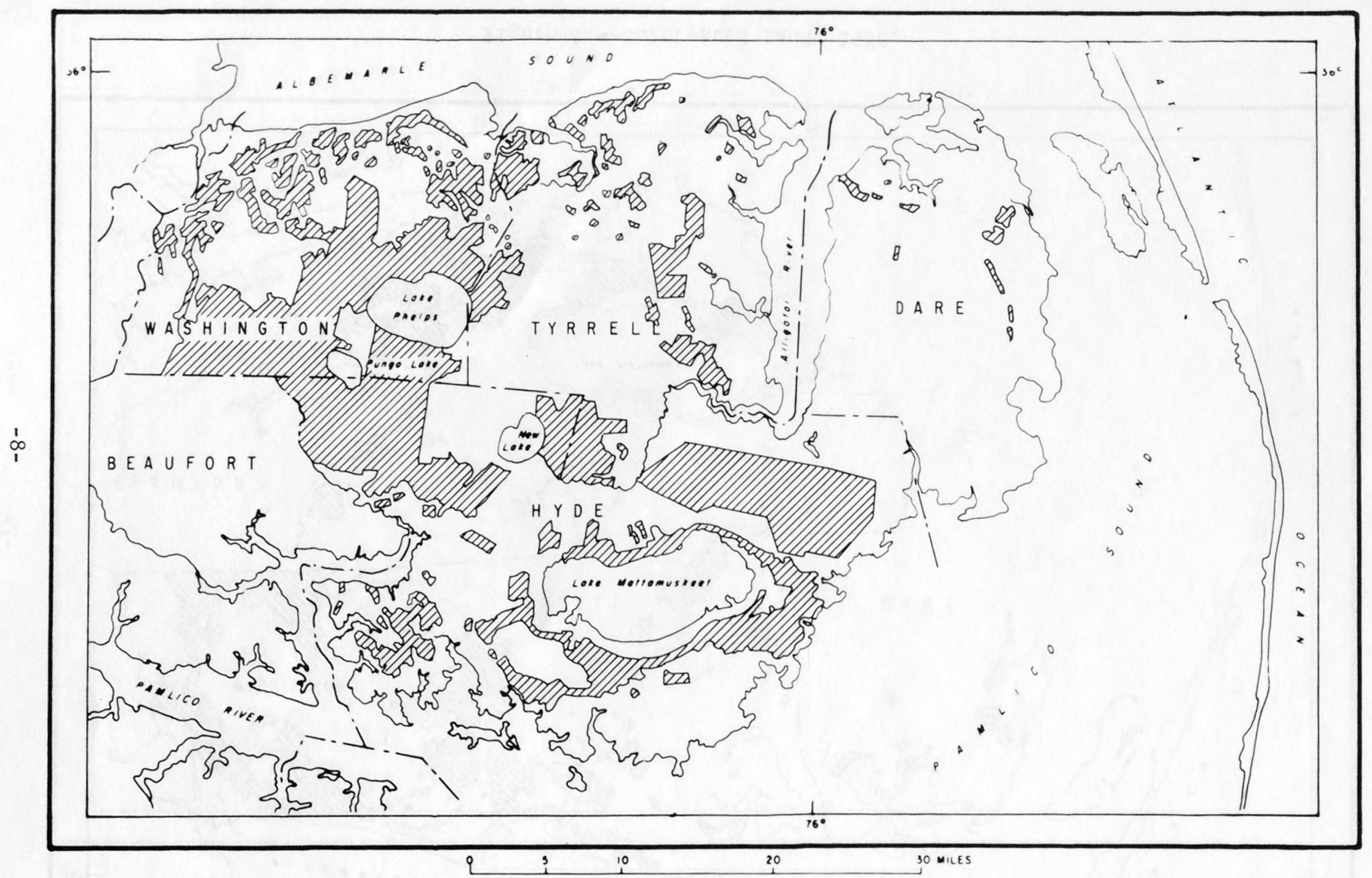

Figure 5.--Cultivated land, 1973. (Based partly on small-scale satellite imagery and may include partially cleared areas not yet under cultivation) 


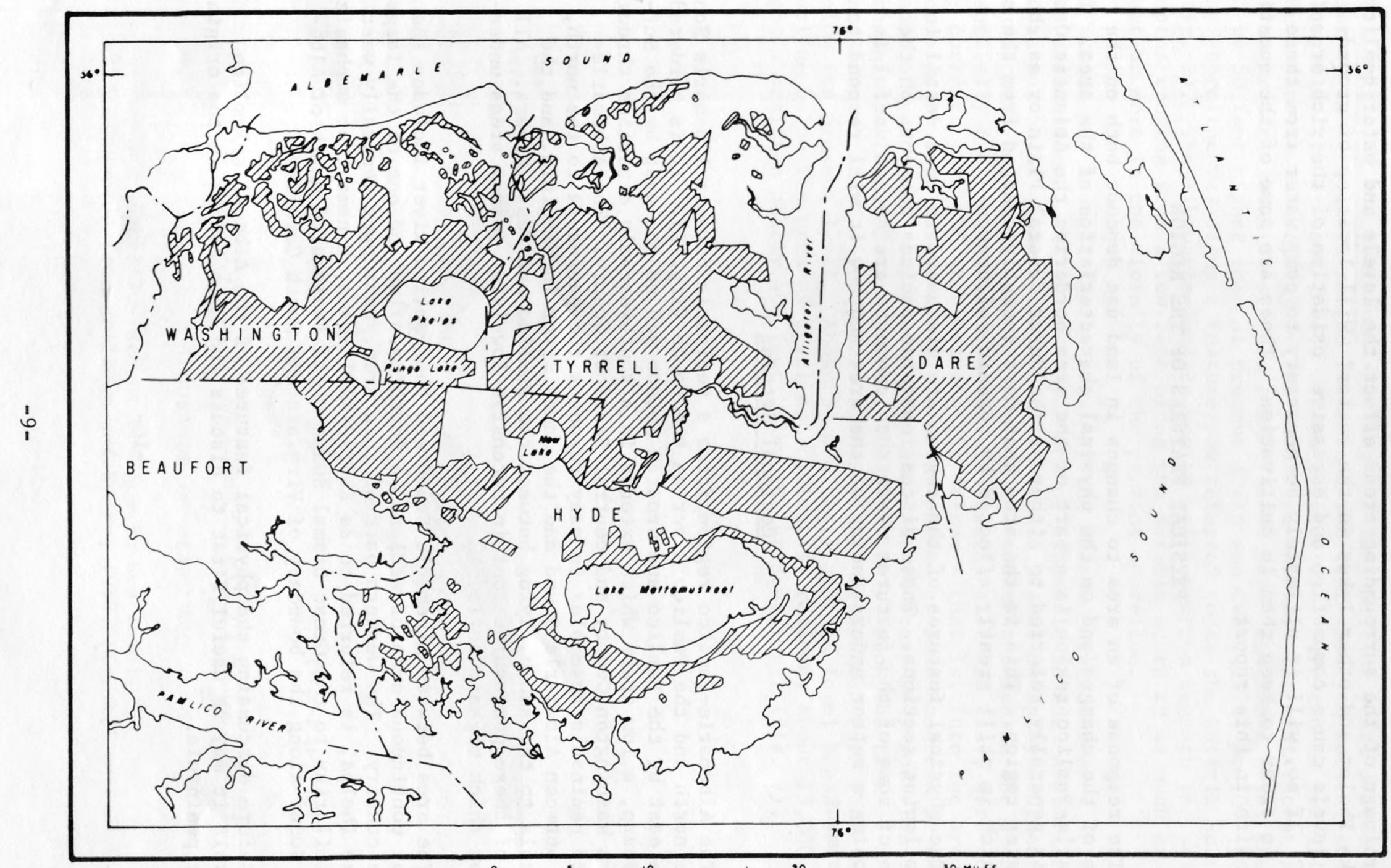

10 
the drainage of the surrounding areas affect the levels and water quality of Lake Phelps and other lakes in the region? Will lowering of groundwater levels cause compaction and excessive oxidation of the rich organic soils? If so, will it ultimately be necessary to pump water from these areas in order to keep them in cultivation? These are some of the questions dealt with in this report.

\section{PHYSICAL FEATURES OF THE REGION}

The response of an area to changes in land use depends both on the nature of the changes and on the physical characteristics of the area. The Albemarle-Pamlico region is a part of the area bordering the Atlantic Ocean that is generally referred to either as the Outer Coastal Plain or as the Tidewater region. This is the area that most recently emerged from the sea and which is still greatly affected by oceanic influences.

The physical features of the region are discussed in some detail in the following sections. These discussions also include comments on the origin of some of the features where such comments are deemed useful in developing a better understanding of the area and how it will respond to development.

\section{$\underline{\text { Regional Setting }}$}

The Albemarle-Pamlico region forms a peninsula between Albemarle Sound on the north and the Pamlico River on the south (fig. 2). It is bordered on the east by the Pamlico and Croatan Sounds and on the west by the Suffolk Scarp, a low scarp which extends in a southwesterly direction through western Washington County and central Beaufort County. The AlbemarlePamlico peninsula resembles in many respects the peninsula to the north, lying between Albemarle Sound and the James River in Virginia, and the peninsula to the south, lying between the Pamlico and Neuse Rivers. A11 three of these peninsulas contain extensive low-1ying swampy areas underlain by thick organic soils.

The area between Albemarle Sound and the Pamlico River includes the largest continuous area of wetland in North Carolina and one of the largest in the country. The western part of this area, that part genera11y west of Lake Phelps, is referred to as East Dismal Swamp, a name that emphasizes its similarity to the Great Dismal Swamp which is located north of Albemarle Sound along the boundary of Virginia and North Carolina.

Before discussing the physical features of the Albemarle-Pamlico peninsula it may be useful first to discuss the main events in the origin of the peninsula. 
Origin of the peninsula - During the last million years of the Earth's history sea level has ranged from about 200 feet above to several hundred feet below its present level. These fluctuations were caused primarily by the expansion and melting of the polar ice sheets. The most recent period of major ice expansion started about 75,000 years ago. Sea level then was 45 to 50 feet higher than at present (Oaks and Coch, 1973, p. 107-108) and the shoreline was along a feature now referred to as the Suffolk Scarp (fig. 2). The Albemarle-Pamlico region was submerged beneath the sea at depths ranging from a few feet along the Suffolk Scarp to as much as 50 feet or more in the vicinity of the present shoreline.

Sediment brought to the coast by the Roanoke River formed a delta in the area now occupied by the upper end of Albemarle Sound. A similar delta was built along the south side of East Dismal Swamp by sediment transported by the Tar River. Some of the sediment reaching the coast, especially the finer-grained materials such as silt and clay, were moved by currents into the area between the deltas - that is, into the area now occupied by East Dismal Swamp. After a period of some hundreds or thousands of years the sea receded from the Suffolk Scarp to a position below present sea level (Oaks and Coch, 1973, p. 108). From the time of this recession to about 35,000 years ago sea level fluctuated both above and below its present level. About 35,000 years ago sea level began to decline below its present level and ultimately reached, about 15,000 years ago, a position nearly 400 feet below its present level (fig。7).

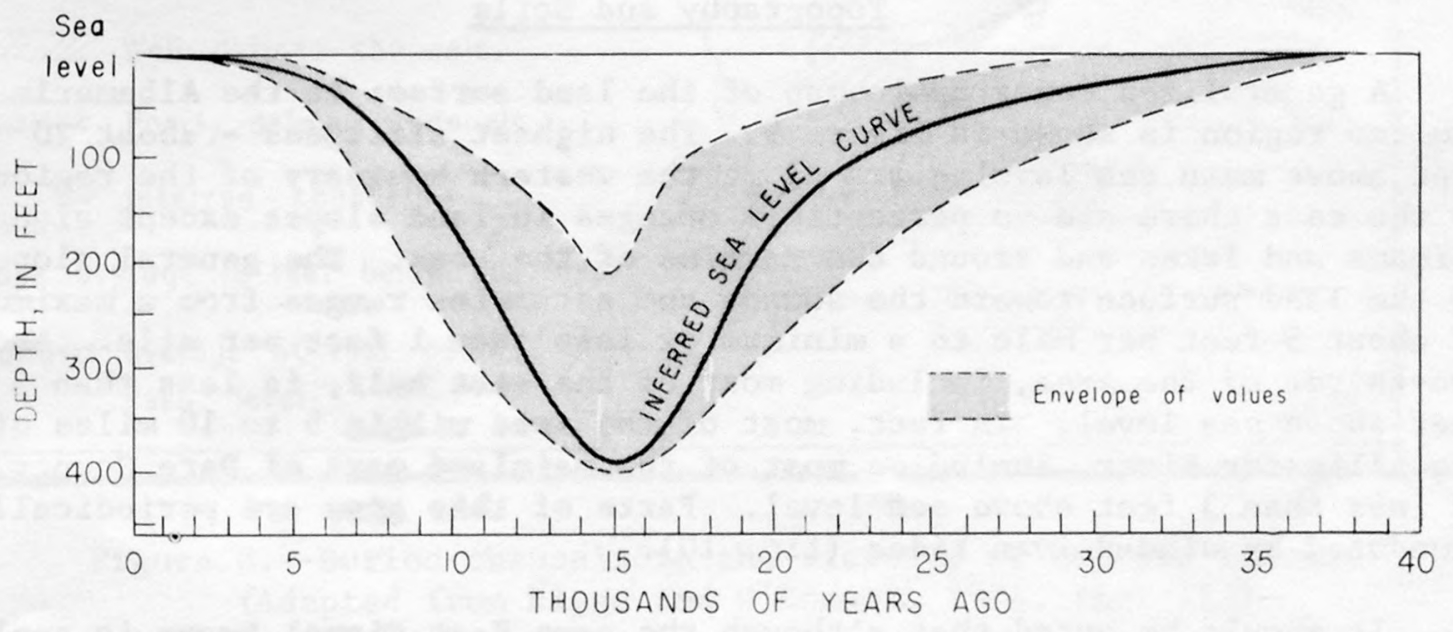

Figure 7.---Recent changes in sea level. (Adapted from Milliman and Emery, 1968, fig. 1. 
During the oscillations of sea level the deltas formed by the Roanoke and Tar Rivers were extended to the east. Remnants of these are preserved as the bands of mineral soils on each side of the peninsula. During the minor readvances of the sea, barrier islands similar to the Outer Banks were probably formed in Tyrre11 County and in the mainland area of Dare County. Although the position and extent of such islands cannot be determined from the information now available, the areas underlain by mineral soils in central and southern Tyrrell County and in Dare County may be remnants of barrier islands. (See fig. 11.)

The withdrawal of the sea from the area was accompanied by an eastward extension and downcutting of the channels of the Roanoke and Tar Rivers and of small streams draining the Albemarle-Pamlico region. Riggs and $\mathrm{O}^{\prime}$ Connor (1974, p. 17) have found evidence of channels as much as 40 feet below present sea level in the vicinity of Roanoke Island. (See fig. 8.) These channels are cut into sediments between 25,000 and 30,000 years old.

In addition to downcutting their channels, the Roanoke and Tar Rivers also formed broad, relatively flat-bottomed valleys. During the rise in sea level over the last few thousand years the lower ends of these valleys have been "drowned" forming, respectively, Albemarle sound and the wide estuary of the Pamlico River. Sea level has been rising at a rate of about 1 foot per century along the East Coast since 1890 (Kaye and Stuckey, 1973, fig. 3) with the result that the shrinkage of the Albemarle-Pamlico region which began 15,000 years ago is still continuing. Studies by Sheridan, Di11, and Kraft (1974, p. 1319) show that about 7,500 years ago the coastline in the vicinity of Delaware was about 7.5 miles east of the present coastline. To reach its present position the sea has advanced on the land at an average rate of more than 5 feet per year.

\section{Topography and Soils}

A generalized topographic map of the land surfac in the AlbemarlePamlico region is shown in figure 9. The highest altitudes - about 20 feet above mean sea level - are along the western boundary of the region. To the east there are no perceptible changes in land slopes except along streams and lakes and around the margins of the area. The general slope of the land surface toward the sounds and estuaries ranges from a maximum of about 5 feet per mile to a minimum of less than 1 foot per mile. About two-thirds of the area, including most of the east half, is less than 5 feet above sea level. In fact, most of the 5 to 10 miles of the Alligator River, including most of the mal County, is less than 3 feet above sea level. Parts of thase periodically inundated by wind-driven tides (fig. 10).

It should be noted that although the name cast 1 is applied only to the area west of Lake Phelps, the entine Suffolk Scarp to Croatan Sound at the east end of they. In fact, those areas less than 5 feet above sea lew include most of the area east of Lake Phelps, are more swampy than higher areas to the west to which the name East Dismal Swamp is applied. 


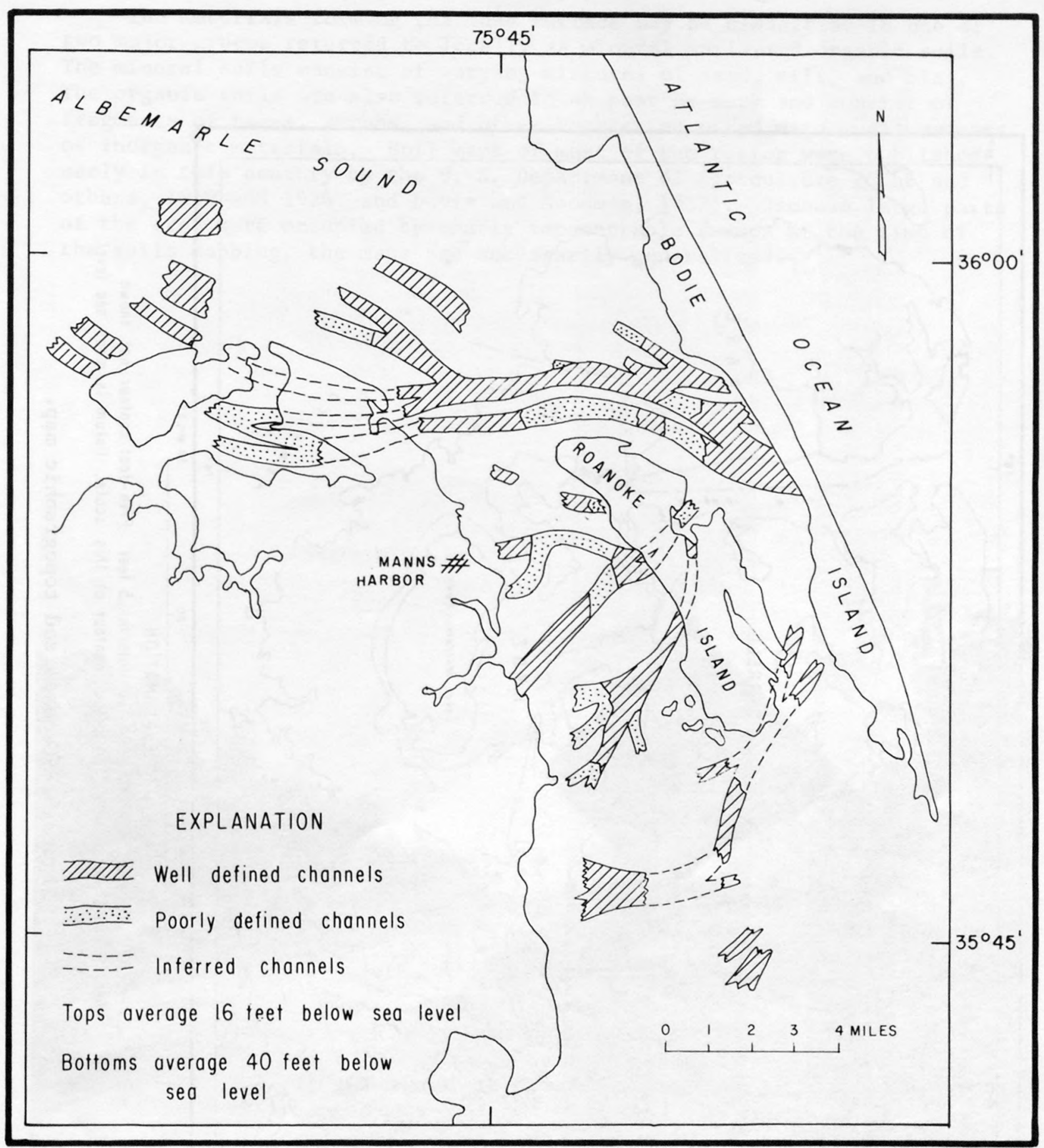

Figure 8.--Buried channe1s in the vicinity of Roanoke Island. (Adapted from Riggs and O'Connor, 1974, fig. 11.) 


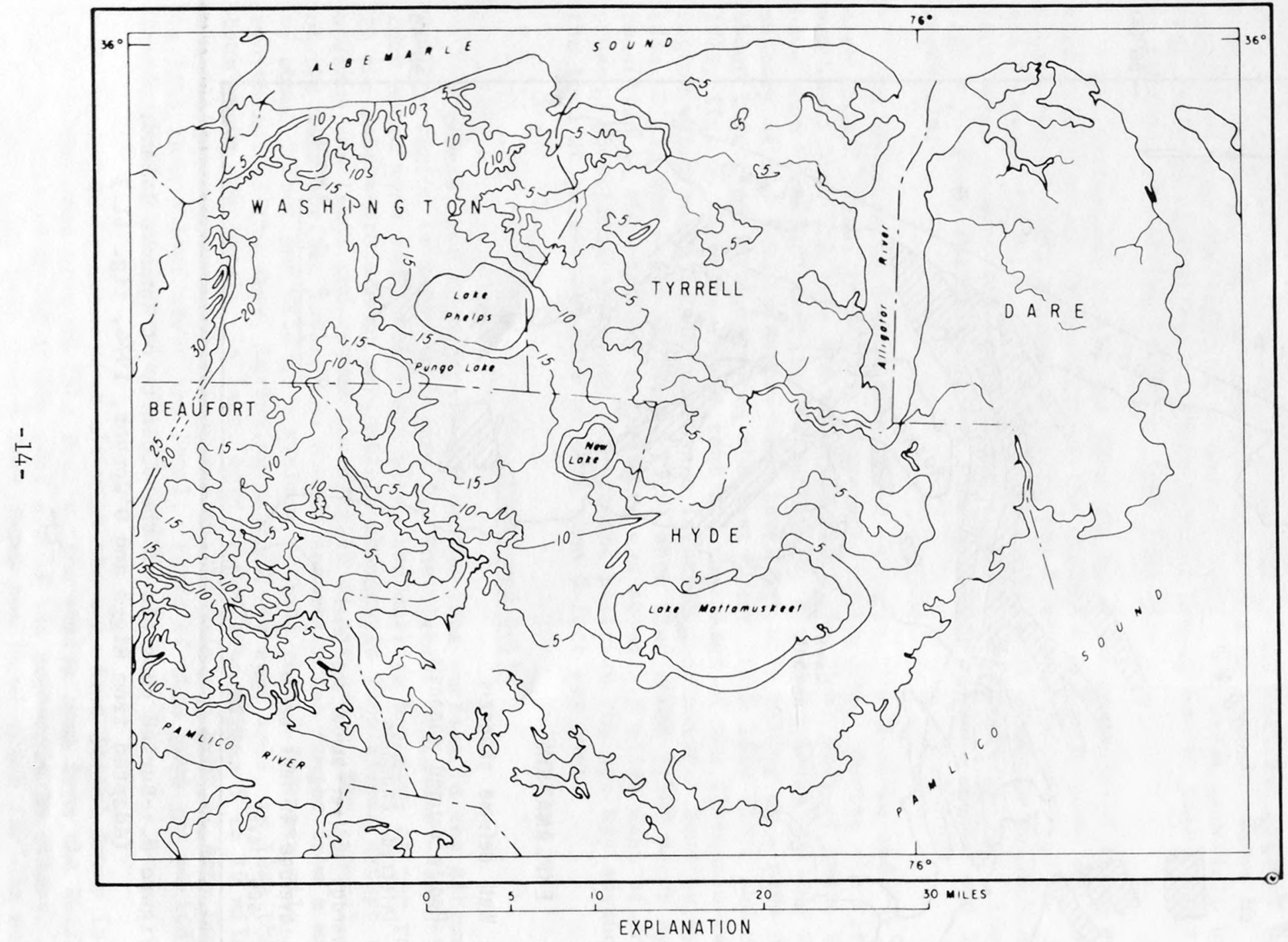

- 5 TOPOGRAPHIC CONTOUR-- Contour interval 5 feet. Five-foot contour not shown

when it would merge with the 10 -foot contour ot this scale. Datum is mean sea level.

Figure 9.--Generalized topographic map. 
The materials forming the land surface may be classified in one of two major groups referred to locally as mineral soils and organic soils. The mineral soils consist of varying mixtures of sand, silt, and clay. The organic soils are also referred to as peat or muck and consist of fragments of trees, shrubs, and other vegetation mixed with small amounts of inorganic materials. Soil maps of most of the region were published early in this century by the U. S. Department of Agriculture (Cobb and others, 1919 and 1924, and Davis and Goodman, 1932). Because large parts of the area were occupied by nearly impenetrable swamps at the time of the soils mapping, the maps are necessarily generalized.

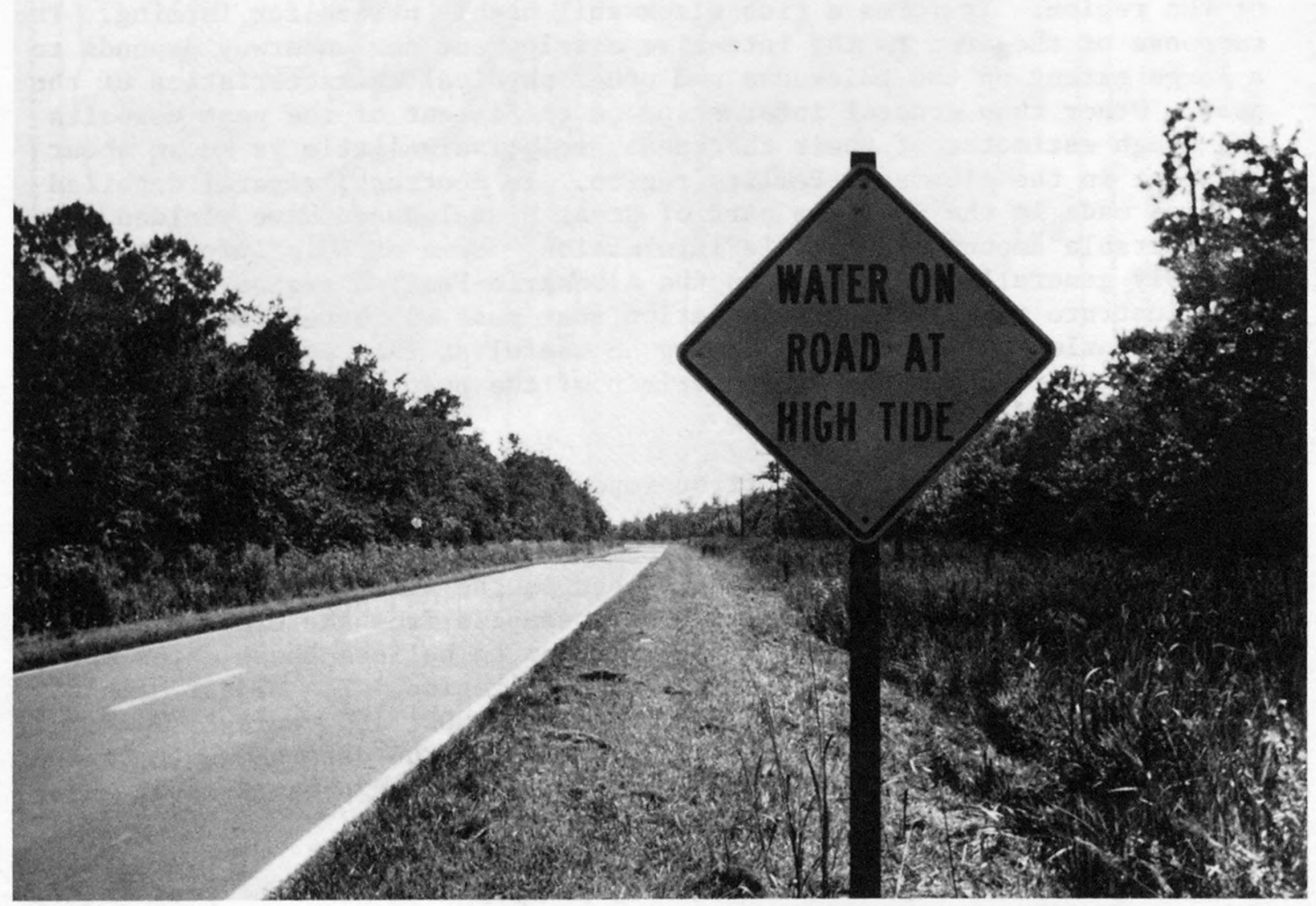

Figure 10。--View along State Highway 94 near Gum Neck. 
For the purposes of this report, the soils have been grouped into three types as shown on figure 11. These types are (1) minera1 soils, which consist of sandy, silty, and clayey loams, (2) thin organic soils, which consist of organic material intermixed with small to moderate amounts of sand, silt, and clay to depths of about 5 feet, and (3) thick organic soils, which consist of organic material more than 5 feet thick containing relatively little sand, silt, and clay. The greatest thickness of organic material now known in the area (1974) is 12 feet (Steve Barnes, oral commun. June 20, 1974). As shown on figure 11, the thin organic soils generally form a transition zone between the mineral soils and the thick organic soils.

From the preceding description it is obvious that this area differs markedly from those areas most of us are familiar with. It is a nearly featureless swamp which slopes gently towards and merges almost imperceptibly into the surrounding sounds and estuaries and which contains extensive and thick deposits of peat.

The peat occurs in a band 10 to 15 miles wide through the centra1 part of the region. It forms a rich black soil highly prized for farming. The response of the area to the intensive development now underway depends to a large extent on the thickness and other physical characteristics of the peat. Other than general information on the extent of the peat deposits and rough estimates of their thickness, relatively little is known about the peat in the Albemarle-Pamlico region. In contrast, several detailed studies made in the Virginia part of Great Dismal Swamp have yielded a considerable amount of valuable information. Some of this information is probably generally applicable to the Albemarle-Pamlico region. Therefore, to illustrate the kinds of information that must ultimately be obtained in the Albemarle-Pamlico region, it may be useful at this point to discuss some of the broad aspects of the origin of the peat, based 1argely on data from Great Dismal Swamp.

Origin of the peat - The first important point to consider relative to the origin of the peat is its age. Because peat is composed of organic material, its age can be readily determined by what are referred to as radiocarbon methods. The age of the peat in the Albemarle-Pamlico region has not yet been determined, but several samples from the Great Dismal Swamp have been dated and there is no reason to believe these dates are not also applicable to the Albemarle-Pamlico region. The oldest samples of peat from Great Dismal Swamp show ages of 8,900 160 years B. P. (before present) (Oaks and Coch, 1973, p. 106). The data shown on figure 7 suggest that sea leve1 was about 130 feet below its present leve1 when the formation of the peat began.

Pollen studies by Whitehead (1972, p. 313) show that the peat in the Great Disma1 Swamp is of fresh-water origin. This is consistent with a sea level we11 below its present level and it is reasonable to assume that the peat in the Albemarle-Pamlico region is also of fresh-water origin except possibly for very young peat in some of the low areas bordering the sounds and the Alligator River. 


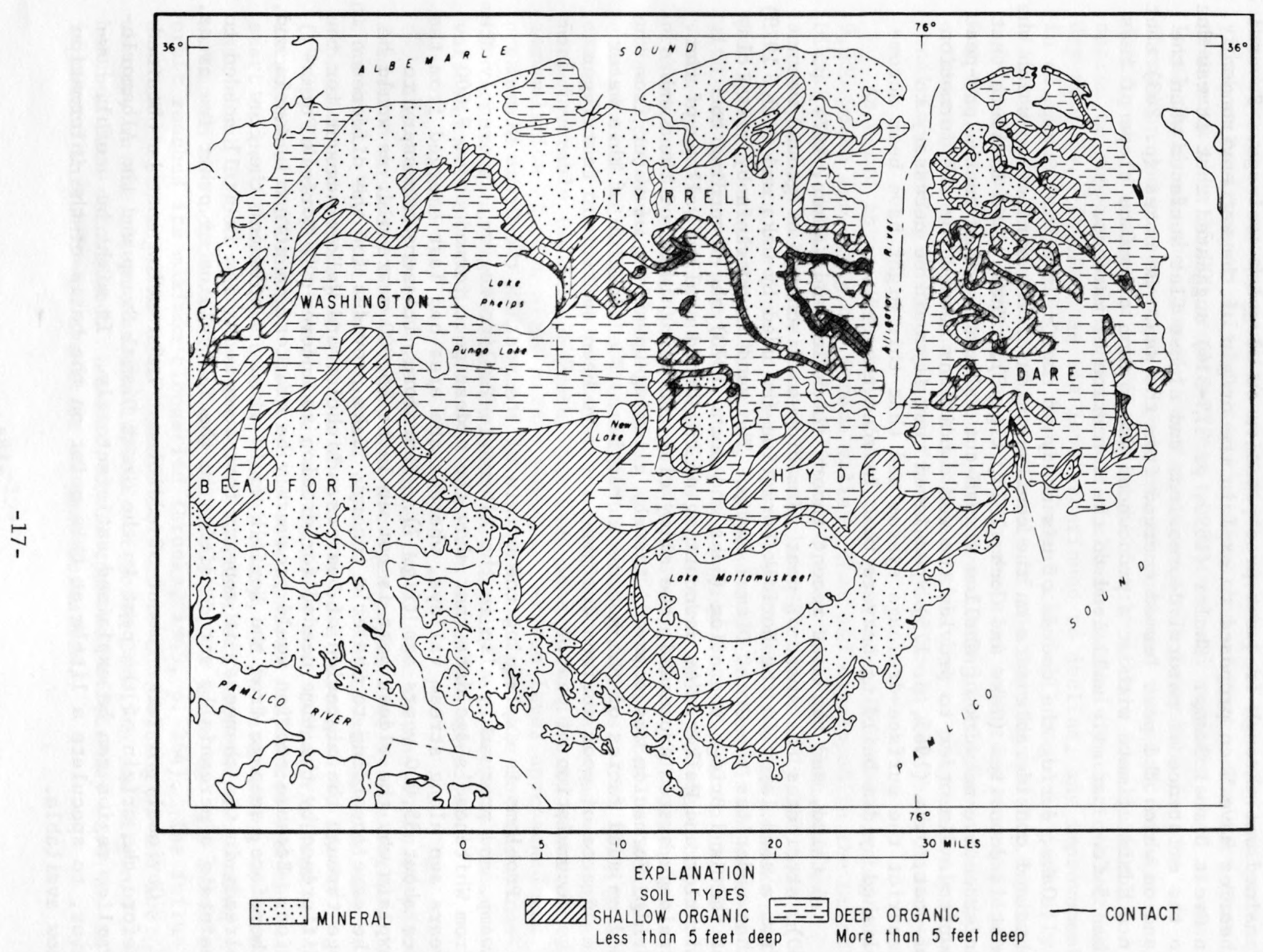

Figure 11.--Generalized soils map. 
Peat can form only in a perennially wet environment. Thus the formation of peat in both the Great Dismal Swamp and the Albemarle-Pamlico region requires either the existence of shallow lakes or of areas that remained wet through frequent precipitation or sluggish drainage. Several theories have been proposed to explain the origin of the wet environment in Great Dismal Swamp. Shaler (1890, p. 313-314) suggested that it was due to the existence of natural depressions and almost flat surfaces when the 1 and on which the peat formed emerged from the sea. He notes (p. 263) that in a humid climate without a pronounced dry season a surface slope of less than 5 feet per mile will lead to the formation of marshes.

Oaks, during the course of his study of the Great Dismal Swamp, obtained considerable data on the configuration of the surface on which the peat is deposited (Oaks and Coch, 1973, fig. 3). These data indicate that an extensive network of shallow stream-cut valleys existed on the pre-peat surface. In order to provide the wet conditions needed for the formation of peat, Oaks (1965, p. 175) speculated that it would be necessary to restrict the surface-drainage system and that this might have been accomplished by dam-building beavers that invaded the area.

A third, and the most recent theory (Lichtler and Walker, 1974, p。 30), attributes the start of peat formation to discharge of ground water from a sand layer in the Norfolk Formation (as used by Oaks and Coch, 1973) that underlies the Great Dismal Swamp. The sand is overlain by silty clay of the Sand Bridge Formation (Oaks and Coch, 1973) and according to Lichtler and Walker, "As downcutting of the broad shallow valleys of the drainage system proceeded, the silty clay confining layer of the Sand Bridge Formation was removed, thereby allowing upwelling of water from the medium sand facies of the Norfolk Formation. The addition of this water in an area of poor surface drainage may have been sufficient to trigger the accumulation of peat."

Problems in explaining the origin of the peat in the Great Dismal Swamp, and presumably also in the Albemarle-Pamlico region, apparently stem from Whitehead's age data that show the oldest peat formed about 9,000 years ago along stream valleys, whereas the area had last emerged from the sea about 35,000 years ago (fig. 7). Therefore, it seems necessary to explain why the oldest peat is not at least 35,000 years old, as would be the case according to Shaler's theory. Oaks provides for the difference in age through the migration of beavers. Lichtler and Walker account for the difference by the time needed for erosion to uncover the Norfolk Formation. Because erosion would presumably be greatest in stream channels and, therefore, seepage from the Norfolk would simply supplement the flow already in the channels, it appears that some mechanism is still needed to maintain a perennially wet condition in the floodplains or other low areas.

Obviously, a large amount of additional information must be obtained before the origin of the peat in the Great Dismal Swamp and the AlbemarlePamlico region can be explained satisfactorily. It might be useful, however, to speculate a little at this point on the basis of the information now available. 
It seems likely that stream channels started to form in the Albemarle-Pamlico region as the sea began its last retreat from the area about 35,000 years ago. Depressions and flat slopes needed for the development of swampy conditions probably existed in the area and provided an environment suitable for the formation of peat. The fact that peat more than 35,000 years old has not been found suggests that as sea level declined, the climatic conditions were not favorable for the formation and preservation of peat or, if peat was formed it was later destroyed. Unfavorable conditions might result either from rainfall too sparse to support lush vegetation or a climate marked by distinct wet and dry periods. In time, as sea level continued to decline, any improvement in climatic conditions (year round abundant rainfall) would be partially offset by the downcutting of the channels of the Roanoke and Tar Rivers and by the related downcutting of the channels of tributary streams draining the Albemarle-Pamlico region. This downcutting would have resulted in a regional lowering of the water table and thus led to progressively dryer conditions during which any peat formed earlier could have been destroyed.

As noted above, Whitehead found that peat first started forming about 9,000 years ago along the stream valleys that had developed in the Great Dismal Swamp area. According to figure 7, sea level at that time was about 130 feet below its present leve1, having risen nearly 300 feet in the 6,000 years previous to then. If major streams like the Roanoke and Tar Rivers, and their tributaries, had graded their channels in concert with the decline in sea level during the period from 35,000 to 15,000 years ago, the rise in sea level from a position about 400 feet below present sea level 15,000 years ago to a position about 130 feet below present sea level about 9,000 years ago would have resulted in considerable channel filling and flattening of stream gradients. The filling of channels and flattening of gradients, combined with the appearance of a more favorable (wetter) climate, may have been sufficient to start the accumulation of peat along stream valleys. As sea level approached its present level about 5,000 years ago, conditions favorable for the formation of peat would have expanded into the higher areas between stream valleys until the entire area of the modern swamp was affected.

The possible importance of a change in climate on the start of peat formation in Great Dismal Swamp has not been emphasized by the workers in that area. The fact that profound changes in climate accompanied the expansion and melting of the ice sheets has been described by Brooks (1949), Zeuner (1952), and others and includes both terrestrial and astronomical influences. Relative to astronomical influences and the start of peat formation in Great Dismal Swamp, it is interesting to note that about 10,500 years ago the earth was farthest from the sun during winter in the northern hemisphere and about 10,000 years ago the earth's orbit reached its maximum elongation (Brooks, 1949, p. 364). The influence of these, together with factors related to the melting of the ice sheets, on the climate at the latitude of North Carolina and Virginia has not been determined. However, their combined effect may have had an important influence on the start of peat formation. 
The natural drainage of the area - that is, the drainage system that existed before man started digging drainage canals - was limited to a few short streams mostly in the western part of the area. The two largest creeks draining to the north were Kendricks Creek (fig. 28), which drained a smal1 area northwest of Lake Phelps, and the Scuppernong River (fig. 28) which drained an area northeast of Lake Phelps. The southwestern part of the area was drained by several short creeks into either the Pamlico or Pungo Rivers. None of these rivers and creeks extended originally more than a few miles into the interior. Overland runoff from the interior apparent1y moved as a sheet-1ike flow over the surface, either to the streams or to the coast.

The Albemarle-Pamlico region contains four lakes (fig. 2). In order of size they are Mattamuskeet, Phelps, New, and Pungo. Physical data on the 1 akes are summarized in table 2, and chemical quality data are shown in table 3. Their surface areas range from $66.7 \mathrm{mi}^{2}$ for Lake Mattamuskeet to $4.4 \mathrm{mi}^{2}$ for Pungo Lake. A11 the lakes are relatively shallow, their average depths ranging from about 5 feet for Lake Phelps to about 2.5 feet for Lake Mattamuskeet. Under natural conditions a11 the lakes were "land locked" in that they were not drained through clearly defined channels.

Table 2.--Physical characteristics of lakes in the Albemarle-Pamlico region

\begin{tabular}{|c|c|c|c|c|c|c|}
\hline $\begin{array}{l}\text { Lake } \\
\text { name }\end{array}$ & $\begin{array}{l}\text { Surface } \\
\text { area } \\
\text { (square } \\
\text { miles) }\end{array}$ & $\begin{array}{c}\text { "Average" } \\
\text { depth } \\
\text { (feet) }\end{array}$ & $\begin{array}{l}\text { "Average" } \\
\text { leve1 above } \\
\text { sea level } \\
\text { (feet) }\end{array}$ & $\begin{array}{c}\text { Bottom } \\
\text { relative to } \\
\text { sea leve1 } \\
\text { (feet) }\end{array}$ & $\begin{array}{c}\text { Altitude of } \\
\text { land surface } \\
\text { above } \\
\text { sea leve1 } \\
\text { (feet) }\end{array}$ & $\begin{array}{c}\text { Storage } \\
\text { (Millions } \\
\text { of } \\
\text { gallons) } \\
\end{array}$ \\
\hline $\begin{array}{l}\text { Matta- } \\
\text { muskeet }\end{array}$ & 66.7 & 2.5 & 0.5 & -2 & $3-5$ & 34,772 \\
\hline Phelps & 25.0 & 5 & 10 & 5 & $11-14$ & 26,066 \\
\hline New & 7.7 & 3 & 9 & 6 & $10-13$ & 4,817 \\
\hline Pungo & 4.4 & 3 & 10 & 7 & $11-14$ & 2,753 \\
\hline
\end{tabular}

Lake Mattamuskeet - Lake Mattamuskeet is the largest natura1 freshwater lake in the State. It is a part of the Mattamuskeet National Wildlife Refuge administered by the U. S. Department of the Interior. Lake Mattamuskeet, as will be discussed in a following section, was the site of an ambitious farming operation in the early $1900^{\prime} \mathrm{s}$. The deepest point in the lake is about 5 feet below sea level. The average depth of the bottom is about 2 feet below sea level (Jim Roberts, oral commun. July 25, 1974). The bottom of the lake is reportedly sandy, except where silts and clays have entered through drainage canals. 
Table 3.--Chemical quality of precipitation and of the lakes in the Albemarle-Pamlico region. Data on precipitation is an average for the region based on maps prepared by Gambell and Fisher (1966)

\begin{tabular}{|c|c|c|c|c|c|}
\hline $\begin{array}{l}\text { Constituent or } \\
\text { characteristic }\end{array}$ & $\begin{array}{l}\text { Precipi- } \\
\text { tation }\end{array}$ & \begin{tabular}{|c|} 
Lake \\
Matta- \\
muskeet \\
$(5-16-74)$ \\
\end{tabular} & $\begin{array}{c}\text { Lake } \\
\text { Phelps } \\
(5-16-74)\end{array}$ & $\begin{array}{c}\text { New } \\
\text { Lake } \\
(5-16-74)\end{array}$ & $\begin{array}{l}\text { Pungo } \\
\text { Lake } \\
(5-16-74)\end{array}$ \\
\hline Silica $(\mathrm{Si02})(\mathrm{mg} / 1) \ldots \ldots$ & & 0.1 & 0.3 & 1.6 & 5.2 \\
\hline Calcium (Ca) (mg/1)....... & 0.4 & 24 & 4.0 & 2.0 & 6.0 \\
\hline Magnesium (Mg) (mg/1)..... & .2 & 39 & 1.4 & 1.0 & 1.9 \\
\hline Sodium $(\mathrm{Na})(\mathrm{mg} / 1) \ldots \ldots \ldots$ & .9 & 420 & 5.4 & 5.3 & 6.3 \\
\hline Potassium (K) (mg/1)...... & .1 & 42 & .9 & .7 & 1.6 \\
\hline Bicarbonate $(\mathrm{HCO} 3)(\mathrm{mg} / 1) \ldots$ & & 6 & 2 & 0 & 4 \\
\hline Sulfate $(\mathrm{SO} 4)(\mathrm{mg} / 1) \ldots \ldots$ & 1.9 & 110 & 15 & 13 & 25 \\
\hline Chloride (C1) (mg/1)...... & 1.1 & 760 & 9.5 & 6.4 & 8.2 \\
\hline Fluoride $(\mathrm{F})(\mathrm{mg} / 1) \ldots \ldots \ldots$ & & .0 & .0 & .0 & .0 \\
\hline $\begin{array}{l}\text { Nitrite }+ \text { nitrate as } \\
\quad \text { Nitrogen } \\
\quad(\mathrm{NO} 2+\text { NO3 as } \mathrm{N})(\mathrm{mg} / 1) \ldots\end{array}$ & $.08^{1 /}$ & .02 & .10 & .24 & .33 \\
\hline $\begin{array}{l}\text { Dissolved solids (Residue } \\
\left.\text { at } 180^{\circ} \mathrm{C}\right)(\mathrm{mg} / 1) \ldots \ldots \ldots\end{array}$ & & 1500 & 54 & 46 & 103 \\
\hline $\begin{array}{l}\text { Sum of mineral constituents } \\
(\mathrm{mg} / 1) \ldots \ldots \ldots \ldots \ldots \ldots\end{array}$ & & 1400 & 38 & 31 & 56 \\
\hline Hardness $(\mathrm{Ca}, \mathrm{Mg})(\mathrm{mg} / 1) \ldots$ & & 220 & 16 & 10 & 24 \\
\hline $\begin{array}{l}\text { Noncarbonate hardness } \\
\qquad(\mathrm{mg} / 1) \ldots \ldots \ldots \ldots \ldots \ldots\end{array}$ & & 220 & 14 & 10 & 20 \\
\hline $\begin{array}{l}\text { Specific conductance } \\
\quad(\text { micro-mhos) } \ldots \ldots \ldots \ldots \ldots\end{array}$ & & 2650 & 75 & 70 & 103 \\
\hline $\mathrm{pH}($ units) $\ldots \ldots \ldots \ldots \ldots \ldots$ & 5.0 & 6.7 & 6.0 & $4 \cdot 6$ & 5.3 \\
\hline $\begin{array}{l}\text { Color (Platinum-Cobalt } \\
\text { units) } \ldots \ldots \ldots \ldots \ldots \ldots \ldots\end{array}$ & & 20 & 3 & 70 & 500 \\
\hline
\end{tabular}

1/ Nitrate as nitrogen 
Lake Mattamuskeet is surrounded by a low "ridge" except for two areas along the northern side of the lake. This ridge ranges in width from a few hundred feet to about half a mile. Its height above sea level ranges from about 4 to 6 feet, in contrast to the surrounding area which has a general altitude of 2 to 4 feet. Because the mixed mineral and organic soils forming the ridge are somewhat better drained than the adjacent areas, nearly all of it is devoted to farming (fig. 3).

The maximum natural stage of the lake was probably somewhat below the top of the ridge but 2 to 3 feet above the present controlled level. It appears likely that under natural conditions discharge from the lake during high stages was by sheet flow through the swamp northward to the Alligator River (fig. 27).

The first effort to control the level of the lake was undertaken in 1838 when the Lake Landing Canal at the east end of the lake was dug by the State (fig. 28)。 Since then three other canals have been dug; two along the south side and the Rosebay Canal at the west end, which was constructed by the Federal Government in 1950. A11 the canals are equipped with control gates. The level of the lake is regulated to meet the needs of the wildlife refuge and since 1966 the level has ranged from about 0.5 foot below sea level to about 2.1 feet above mean sea level. During this period the average annual lake level has ranged from slightly above sea level in 1966 to about 0.5 foot above sea level since 1971 (fig. 12). When lake level is maintained at 0.5 foot above sea leve1, the average depth of the lake is about 2.5 feet.

Lake Phelps - Lake Phelps is the second largest 1 ake in the area and forms the major part of Pettigrew State Park. The lake reaches a maximum depth of about 7 feet near the center and its average depth is about 5 feet. The bottom of the lake is sandy except for an area underlain by muck along the northwest side (Simon Rich, oral commun. July 23, 1974). Like Lake Mattamuskeet, Lake Phelps is also partly surrounded by a low "ridge." This ridge is absent along the northwest side of the lake and, where present, is less distinct than that around Lake Mattamuskeet. Natural overflow from the lake was by sheet flow through the swampy area at the northwest corner northward to the Scuppernong River (fig. 27)。

The level of Lake Phelps is now controlled by four canals that have been dug from the northeast side of the lake to the Scuppernong River. The first of these canals was dug in 1787 (fig. 28). A11 are equipped with control gates which in the early 1950's had become inoperative with the result that water overflowed from the lake through the natural discharge area along the northwest side (Robert Spear, oral commun. July 24, 1974). Prior to this, in the early $1940^{\prime} \mathrm{s}$, the level of the lake was so low that hunters drove around the margin of the lake to hunt deer on the south side.

Regular measurements of the level of Lake Phelps were started at Pettigrew State Park in June 1965 using a yardstick nailed to the park dock (fig. 13). This was removed in April 1970 when the U. S. Army, Corps of 

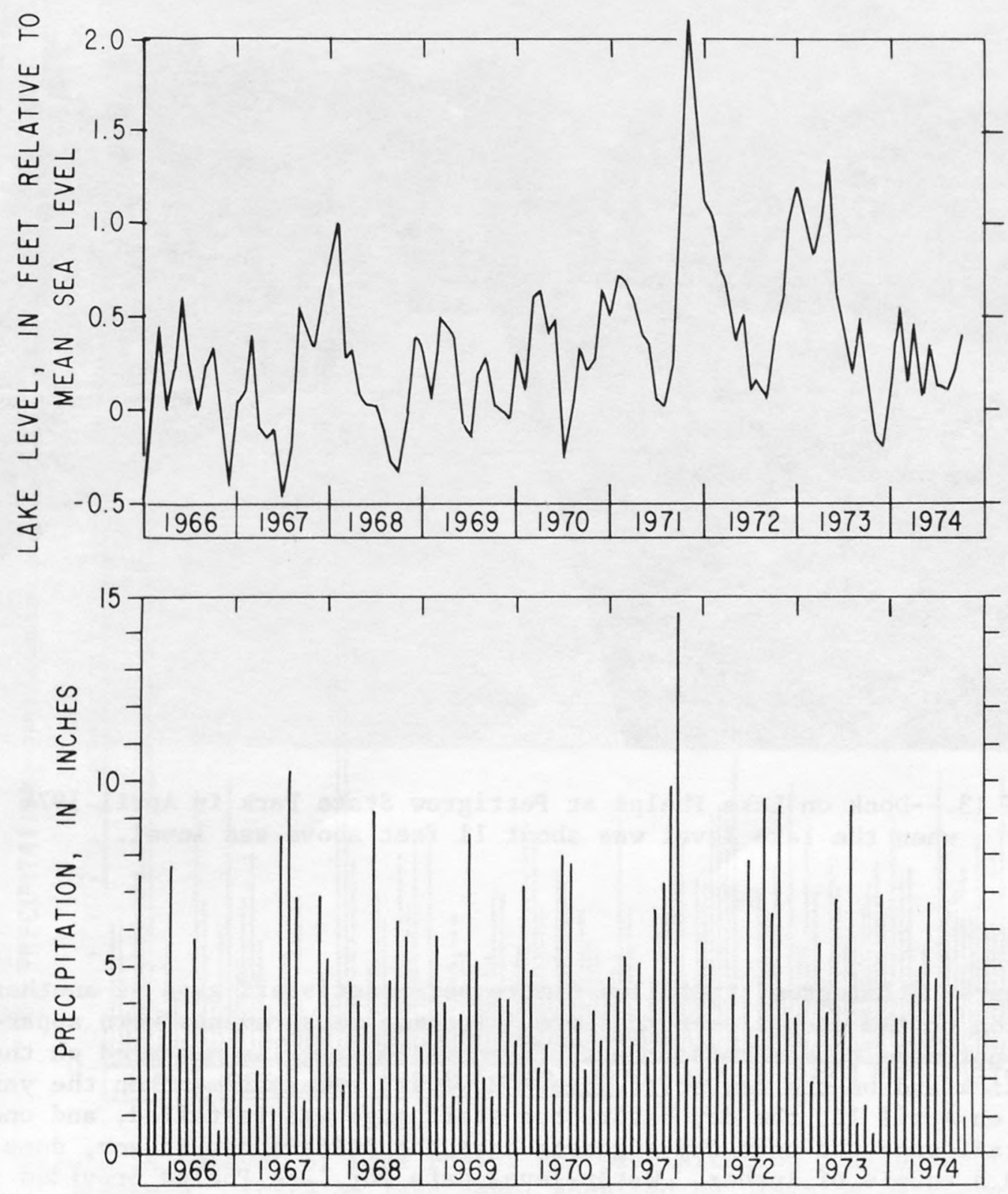

Figure 12.-- Leve1 of Lake Mattamuskeet and precipitation at New Holland. (Data on lake level supplied by U. S. Bureau of Sports Fisheries and Wildlife. Precipitation data from records of National Weather Service.) 


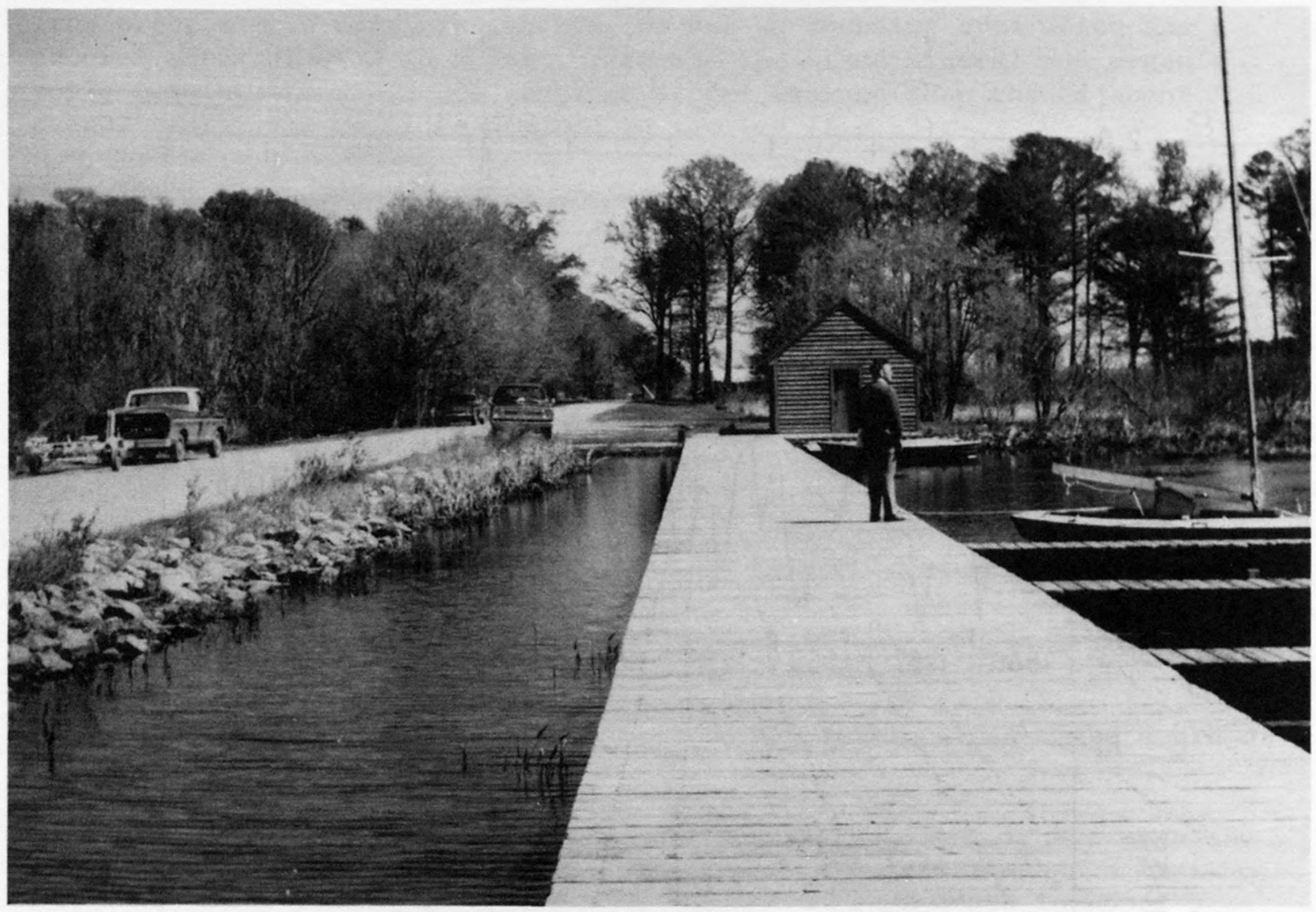

Figure 13.--Dock on Lake Phelps at Pettigrew State Park in Apri1 1974 when the lake level was about 11 feet above sea level.

Engineers, Wilmington, installed a more permanent staff gage at another position on the dock closer to shore. Precise measurements were apparently not made to determine the differences in stage as measured on the yardstick and on the new staff gage. However, a measurement on the yardstick on April 15, the day before the staff gage was installed, and one on the staff gage the next day suggests that the difference, if any, does not exceed a couple of inches. Water-leve1 data for Lake Phe1ps provided by the Division of State Parks is shown in figure 14. From 1967 to 1969 the level of the lake is reported to have been below the bottom of the yardstick. From May 1970 to December 1971 the leve1 of the lake is reported to have been below the staff gage which, because of a shallower 

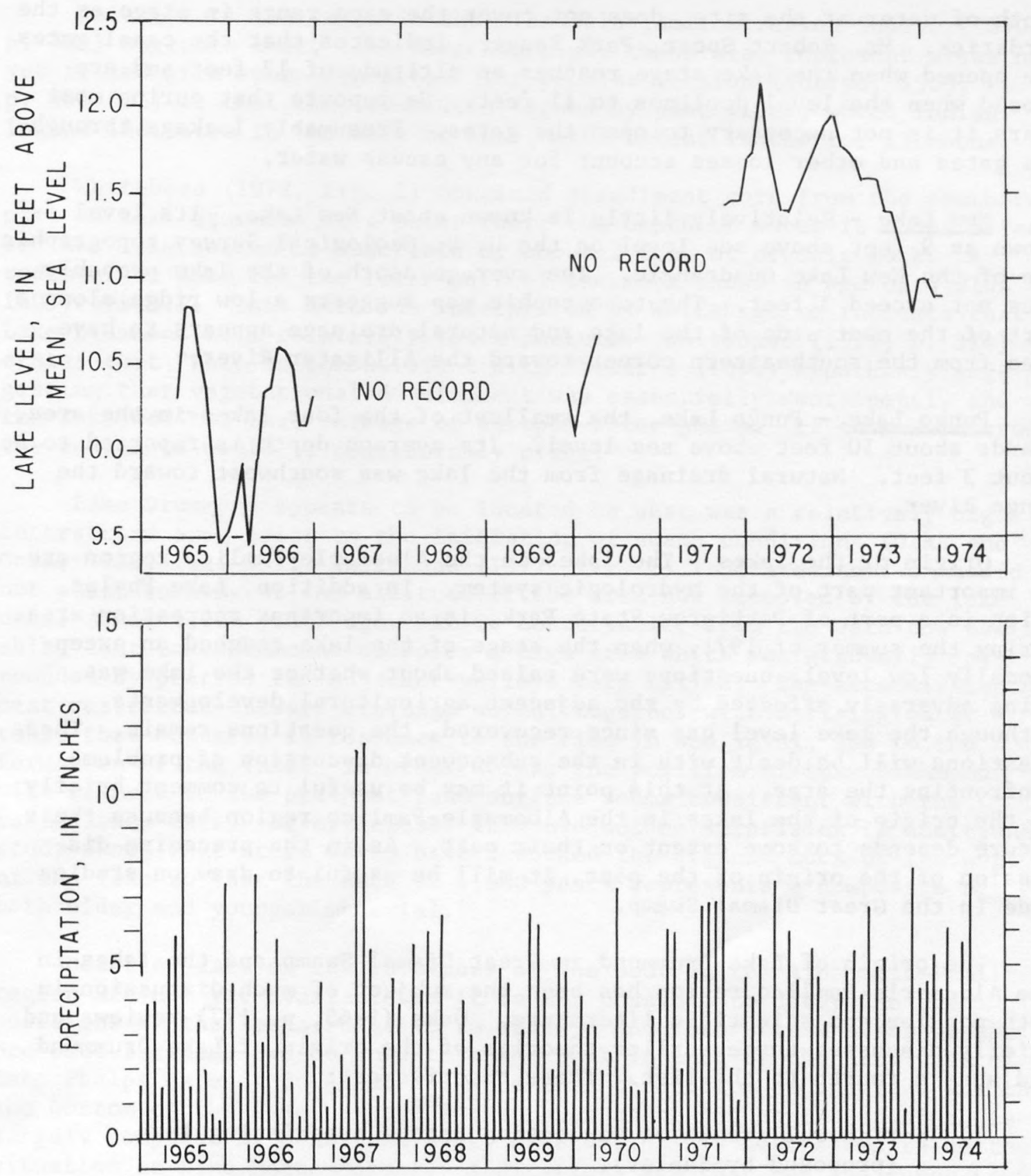

Figure 14.--Leve1 of Lake Phe1ps and precipitation 5 miles east of Plymouth. (Data on lake level supplied by Division of State Parks. Precipitation data from records of National Weather Service.) 
depth of water at the site, does not cover the same range in stage as the yardstick. Mr. Robert Spear, Park Ranger, indicates that the canal gates are opened when the lake stage reaches an altitude of 12 feet and are closed when the level declines to 11 feet. He reports that during most years it is not necessary to open the gates. Presumably leakage through the gates and other losses account for any excess water.

New Lake - Relatively little is known about New Lake. Its level is shown as 9 feet above sea level on the U. S. Geological Survey topographic map of the New Lake Quadrangle. The average depth of the lake probably does not exceed 3 feet. The topographic map suggests a low ridge along a part of the east side of the lake and natural drainage appears to have been from the southeastern corner toward the Alligator River.

Pungo Lake - Pungo Lake, the smallest of the four lakes in the area, stands about 10 feet above sea leve1. Its average depth is reported to be about 3 feet. Natural drainage from the lake was southwest toward the Pungo River.

Origin of the lakes - The lakes in the Albemarle-Pam1ico region are an important part of the hydrologic system. In addition, Lake Phelps, which is a part of Pettigrew State Park, is an important recreation area. During the summer of 1971, when the stage of the lake reached an exceptionally low level, questions were raised about whether the lake was being adversely affected by the adjacent agricultural developments. Although the lake level has since recovered, the questions remain. These questions will be dealt with in the subsequent discussion of problems confronting the area. At this point it may be useful to comment briefly on the origin of the lakes in the Albemarle-Pamlico region because their future depends to some extent on their past. As in the preceding discussion of the origin of the peat, it will be useful to draw on studies made in the Great Dismal Swamp.

The origin of Lake Drummond in Great Dismal Swamp and the lakes in the Albemarle-Pamlico region has been the subject of much discussion in both popular and scientific literature. Oaks (1965, p. 177) reviews and briefly discusses three earlier theories of the origin of Lake Drummond and adds a fourth to the list. These theories are:

1. peripheral growth of vegetation into a preexisting lake (proposed by Shaler),

2. fire which destroyed the peat in the area occupied by the lake (Indian legend mentioned by Shaler),

3. meteorite impact, and

4. solution of a she11 layer in the underlying sediments and collapse of the surface into the depression (proposed by Oaks). 
Relative to the lakes in the Albemarle-Pamlico region Shaler (1890, p. 321) suggests that, like Lake Drummond, these also represent areas not yet filled with swamp deposits. The popular version (Sharpe, 1966, p. 900-901) is that the lakes were formed by peat fires, which Indian legend indicates in the case of Lake Mattamuskeet lasted for 13 moons.

Whitehead (1972, fig. 2) obtained a sediment core from the southern part of Lake Drummond at a point where the depth of water is about 5 feet and the lake bottom is underlain by about 2 feet of organic muck. A radiocarbon date for the lower part of the muck shows an age of $4,210^{ \pm}$ 160 years B.P. This date was interpreted by Whitehead to indicate that Lake Drummond is a relatively young feature. Whitehead (1972, p. 314) states that "This is inconsistent with Shaler's (1890) hypothesis suggesting that vegetational development was essentially centripetal, and the lake was the last vestige of an open-water phase. If this were true, the sediments would be considerably older."

Lake Drummond appears to be located on what was a relatively high interstream area prior to the initiation of swamp conditions (Oaks and Coch, 1973, fig. 33). Whitehead (1972, fig. 8) indicates that peat did not start forming at the altitude of the area now occupied by the lake until about 6,000 years ago. It is conceivable, from the data now available, that Lake Drummond occupies a high area which was gradually surrounded by peat as the adjacent valleys were filled. The accumulation of peat restricted outward drainage which, together with a rising water table that occurred in response to the rise in sea level, led to the formation of the lake. In other words, the position of Lake Drummond with respect to the pre-peat land surface seems consistent with the radiocarbon date. Nevertheless, it would not be surprising if additional study shows that storm waves have reworked the organic muck of the bottom of the lake so that the date of 4,000 years represents a composite age of both older and younger material.

Detailed data on the thickness of the peat in the Albemarle-Pamlico region are not yet available so it is not possible to determine the positions of the lakes relative to valleys and interstream areas on the pre-peat surface. We do know that the peat in part of the area west of Lake Phelps extends to greater depths than the bottom of the lake and that the bottom of the lake, except for an area along the northwest side, is largely composed of sandy and silty material. This also seems to be the situation at Lake Mattamuskeet. Indications are that New and Pungo Lakes are underlain by layers of organic muck.

On the basis of the information available at this time, it seems likely that the lakes in the Albemarle-Pamlico region occupy relatively high areas between valleys eroded into the pre-peat surface. If so, the lakes may have formed as a consequence both of the buildup of peat in the surrounding areas to the point where surface drainage was restricted and of a rise in the water table in response to the rise in sea level. What about the low ridges that partly surround the larger lakes? The fact that they are best developed around the larger lakes suggests that they 
were formed with sand and silt eroded from the bottoms of the lakes by waves generated during the passage of major storms. This material was and is being deposited on and mixed with the organic material forming around the margins of the lakes. These ridges probably represent the maximum extent of the lakes prior to the construction of drainage canals.

\section{Geology of the Region}

The Albemarle-Pamlico region is underlain by a wedge-shaped mass of unconsolidated sediments ranging in thickness from about 2,000 feet along the western boundary to about 6,500 feet along the eastern boundary. These sediments rest on a bedrock surface that slopes toward the east at a rate of about 70 feet per mile (fig。15). They consist of complexly interbedded layers of clay, silt, sand, and limestone. Only the upper part of the sediments underlying the region are of prime importance from the standpoint of hydrologic conditions. These are the sediments containing fresh water and which serve as an important source of water for the area.

The sediments containing fresh water are divided by geologists into four units. Starting at 1 and surface these units are (1) Quaternary deposits, (2) Yorktown Formation, (3) Pungo River Formation, and (4) Castle Hayne Limestone. Figure 16 shows the position of these units with respect to land surface and also their general composition. In the western part of the area two sedimentary units are shown underlying those mentioned above. These units, consisting of sediments of Paleocene and Cretaceous age, are not discussed in the following sections.

Quaternary deposits - The Quaternary deposits include the soil zone described earlier and the underlying sediments to depths ranging from about 40 feet in the western part of the area to about 200 feet in the eastern part (fig. 17). This unit consists of sediments deposited in the area since the end of Pliocene time - that is, during the last 1.8 miliion years.

Below the soil zone the Quaternary sediments are composed of interbedded layers and lenses of sand, silt, clay, and mollusk shells. Sand is most abbundant in the western part of the area and in the delta remnants adjacent to Albemarle Sound and the Pamlico River.

The Quaternary sediments are of key importance to the hydrology of the area. They absorb rain falling on the area and either transmit it downward to deeper water-bearing zones or 1atera11y to lakes and streams. When full of water - so that no more can be absorbed - they form the surface on which overland flow occurs. Sand layers in the Quaternary sediments serve as the primary source of water supply in Dare County and are important sources of water supply to shallow wells throughout the region (Nelson, 1964, p. 23). Yields of 5 to $10 \mathrm{gal} / \mathrm{min}$ can be obtained from sma11-diameter wells screened in these layers. 


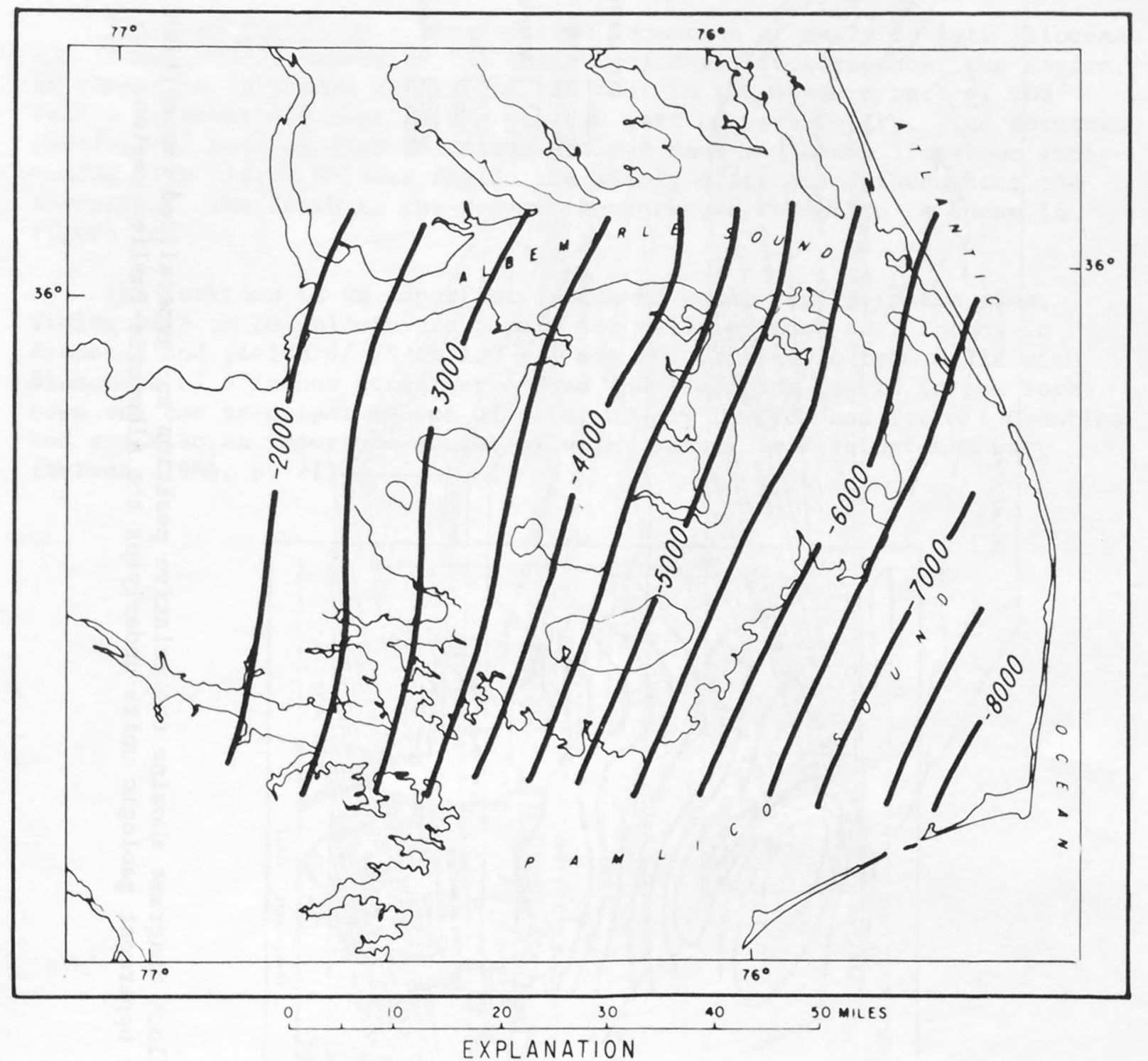

- Line of equal depth to top of bedrock. Interval 500 feet. Datum is mean sea level.

Figure 15.--Depth to the top of bedrock. (Adapted from Brown, Miller, and Swain, 1972, p1. 5.) 

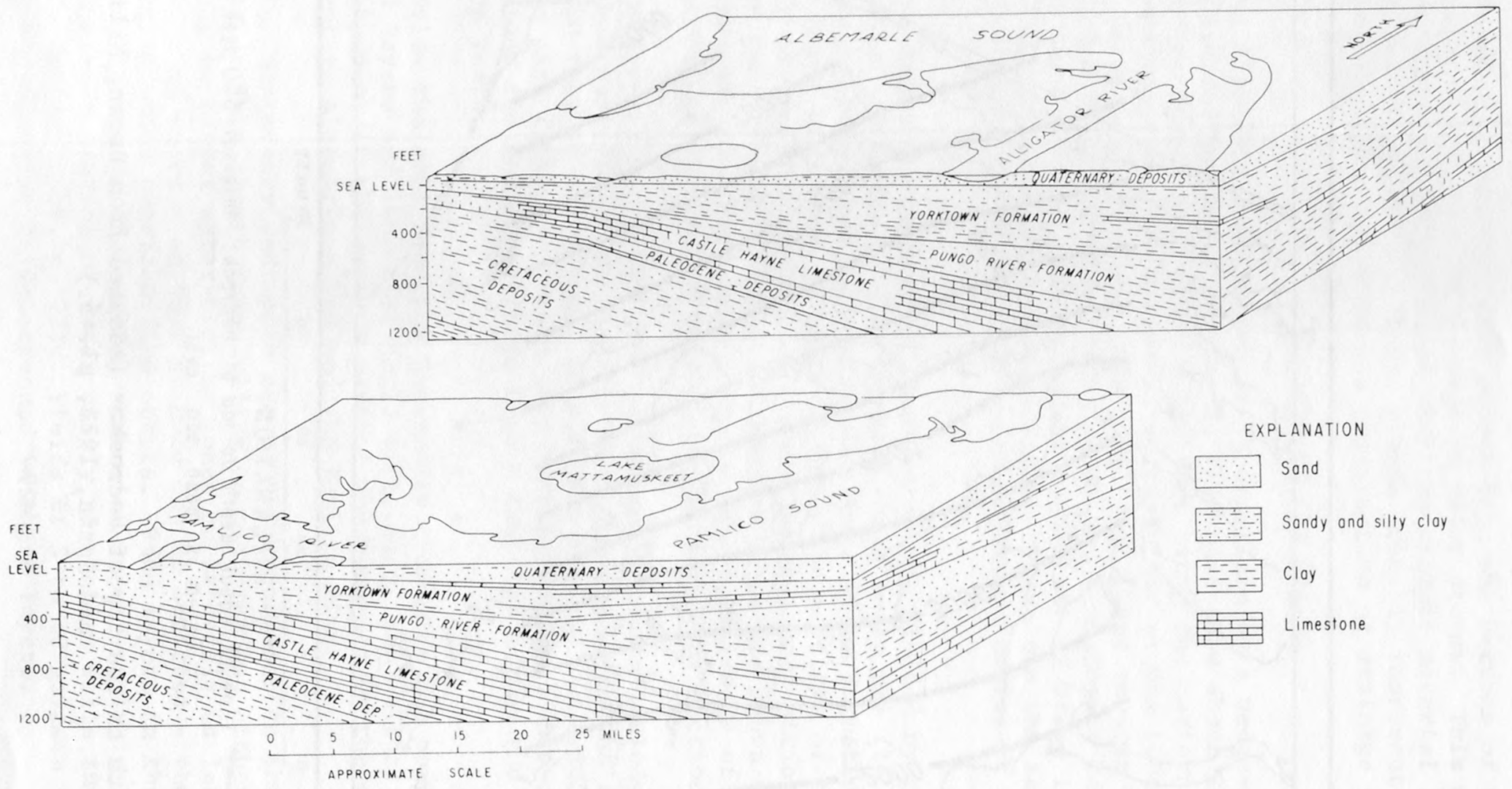

Figure 16.--Block diagrams showing the relative position and generalized composition of the uppermost geologic units underlying the Albemarle-Pamlico region. 
The Quaternary sediments, including the soil zone, are of critical importance to effective management of the agricultural operations in the region. Both cropping practices and the design and operation of drainage structures depend on detailed knowledge of these sediments. Such knowledge is not now available.

Yorktown Formation - The Yorktown Formation of early to late Pliocene age (Haze1, 1975) underlies the Quaternary deposits throughout the region. It ranges in thickness from about 150 feet in the western part of the region to about 450 feet in the eastern part of Dare County. The Yorktown consists of beds of fine to coarse-grained sand and sandy limestone interbedded with clay. Mollusk shells are widely distributed throughout the formation. The depth to the top of the Yorktown Formation is shown in figure 18 .

The Yorktown is an important source of water supply in the area. Yields of 5 to $20 \mathrm{gal} / \mathrm{min}$ are common for wells as much as 2 inches in diameter and yields of 75 to $100 \mathrm{gal} / \mathrm{min}$ are obtainable from we11s with diameters of 6 inches or larger. Sand and limestone layers in the Yorktown are the principal source of water supply in Hyde and Tyrrell Counties and are also an important source of water supply in Washington County (Ne1son, 1964, p. 21).

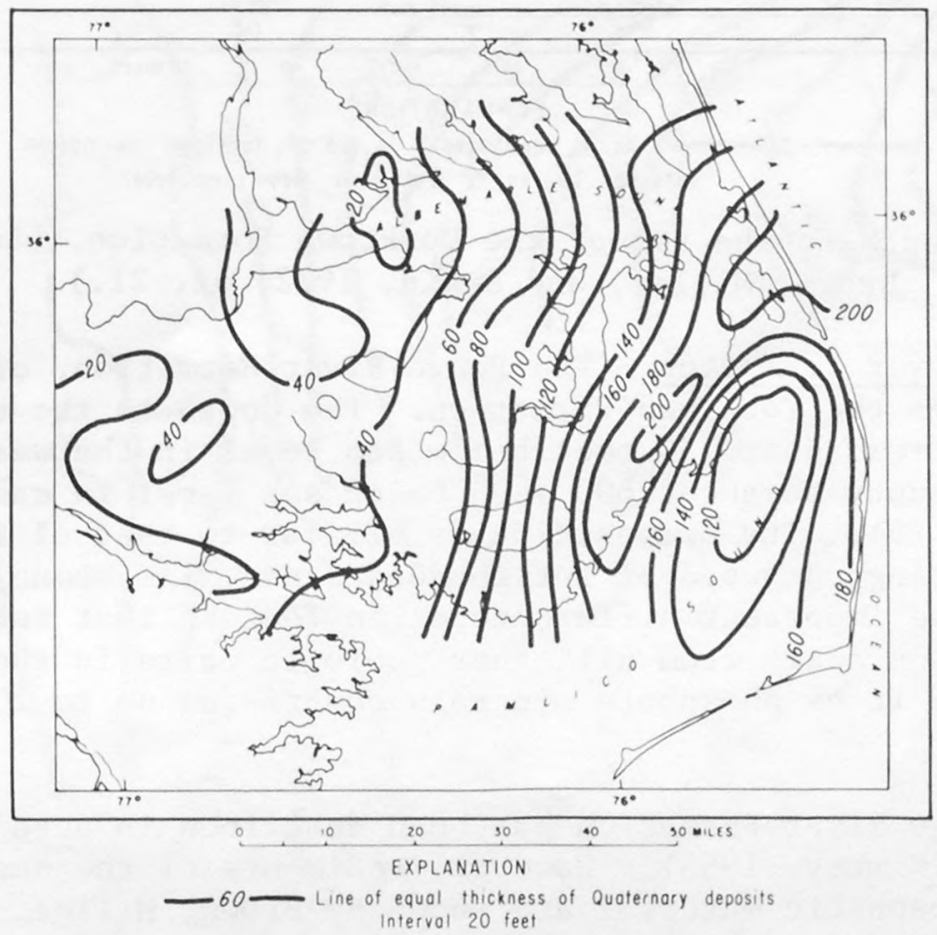

Figure 17.--Thickness of the Quaternary deposits. (Adapted from Brown, Miller, and Swain, 1972, p1. 22.) 


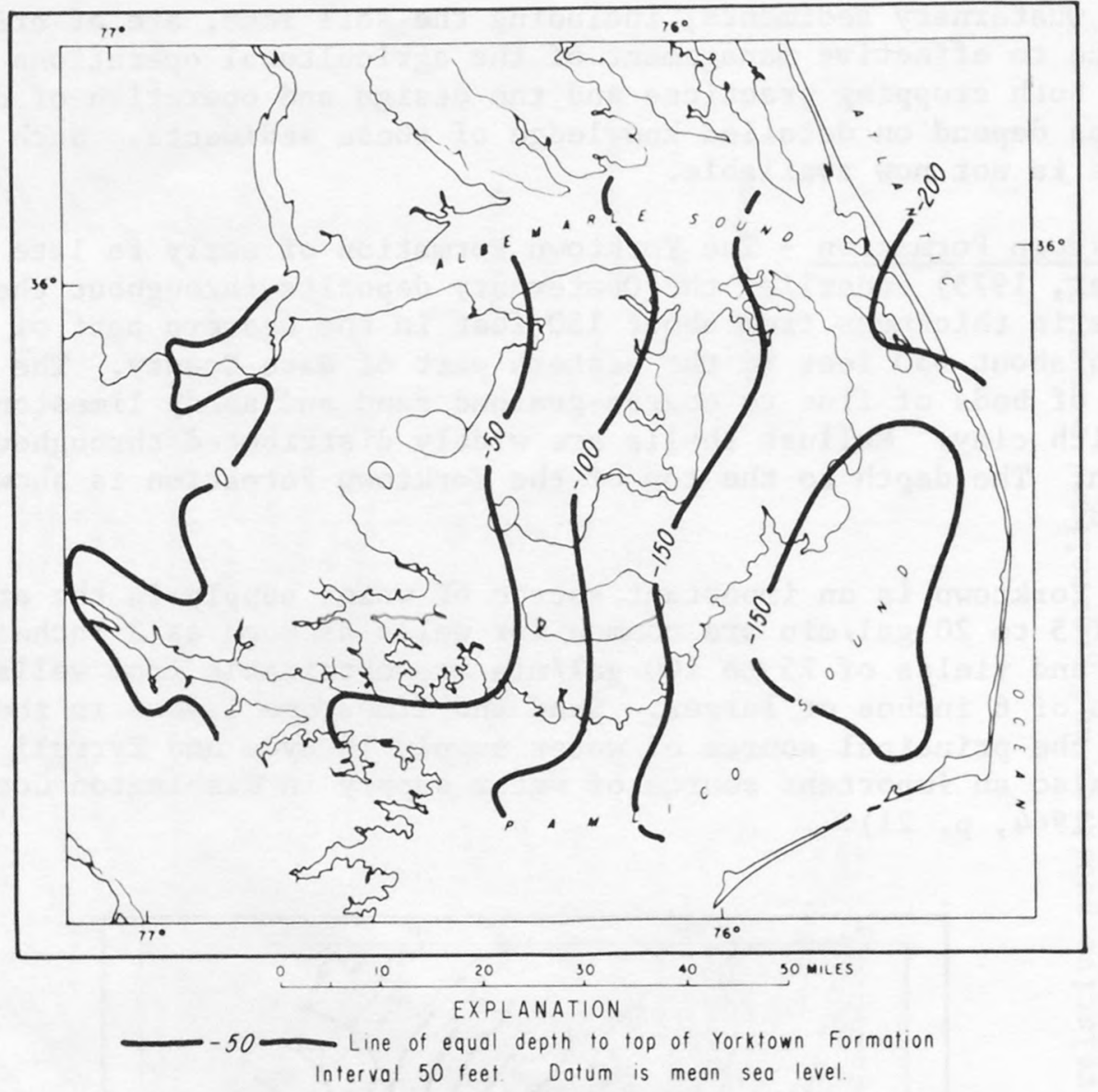

Figure 18.--Depth to the top of the Yorktown Formation. (Adapted from Brown, Miller, and Swain, 1972, p1. 21.)

Pungo River Formation - The Pungo River Formation, of middle Miocene age, underlies the Yorktown Formation. The depth to the top of the formation ranges from about 150 feet below sea level in the western part of Washington County to about 600 feet below sea level in eastern Dare County (fig. 19). Its composition is similar to that of the Yorktown Formation, being composed of interbedded sands, 1imestone, and clay, except for one important difference. The feature that sets the Pungo River Formation apart from all other geologic units in the region is the occurrence in it of phosphate minerals comprising up to 20 percent of some layers.

The Pungo River Formation has been described in detail only in Beaufort County (Kimrey, 1965). However, sediments of the same age and including phosphatic material are shown by Brown, Miller, and Swain (1972) to underlie the entire Albemarle-Pamlico region.

Although the Pungo River Formation is not important as a source of water supply, its presence in the region has had a profound effect on water resources. This effect is a result of the method of phosphate 
mining adopted for the formation in the area south of the Pamlico River. In that area the phosphate is mined by the dry, open-pit method which requires lowering of ground-water levels below the formation. The dewatering is accomplished by withdrawing water through wells from the underlying Castle Hayne Limestone (N. C. Groundwater Section, 1974, p. 43). The effect of this dewatering on the hydrology of the Albemarle-Pamlico region will be discussed in the section on development of the region.

The top of the Pungo River Formation occurs at a depth of about 80 feet below sea level at the mine in Beaufort County. The depth to the top of the formation is greater than that in all of the Albemarle-Pamlico region except in the western part of Washington County (fig. 19).

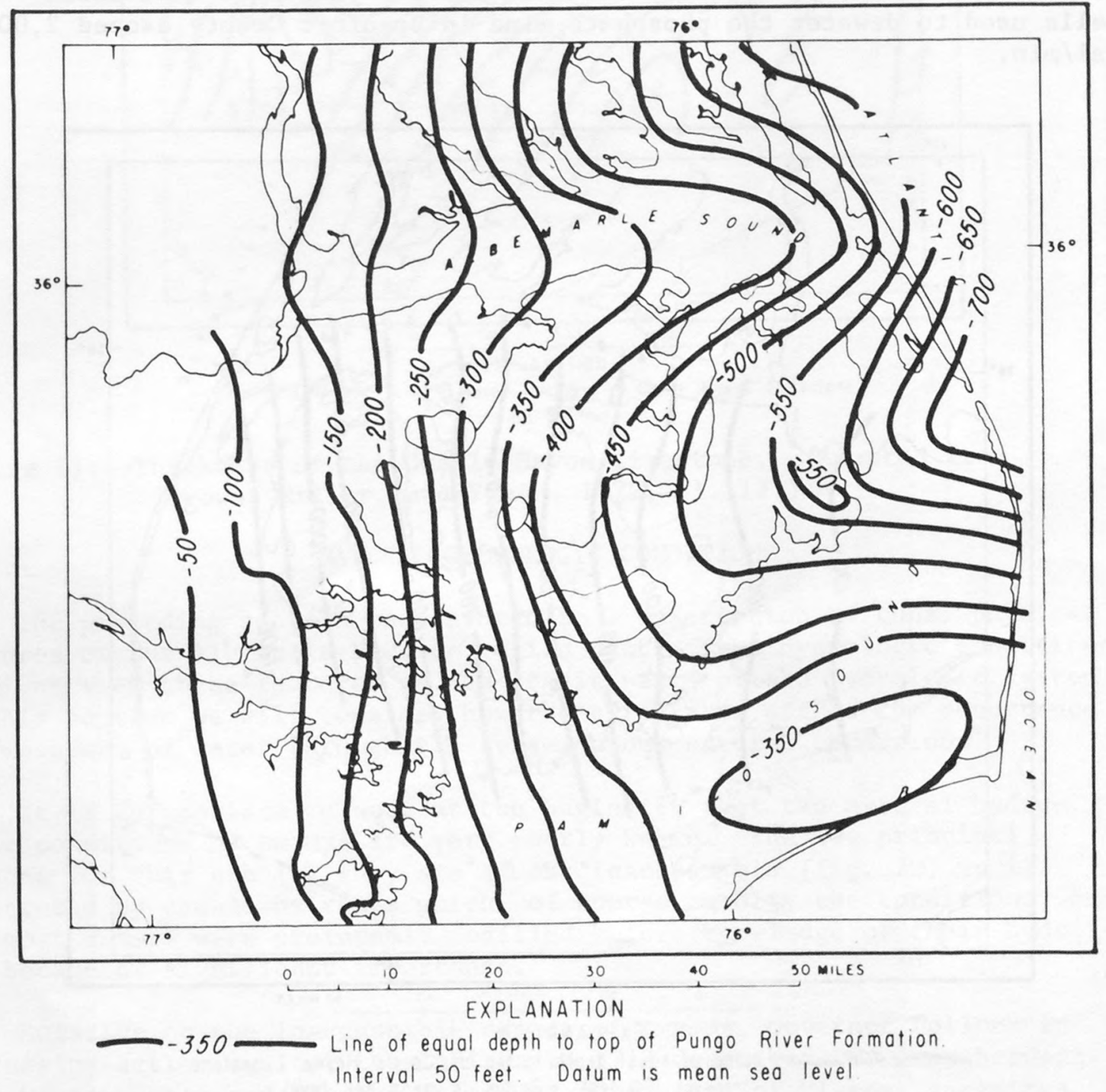

Figure 19.--Depth to the top of the Pungo River Formation. (Adapted from Brown, Miller, and Swain, 1972, p1. 20.) 
Castle Hayne Limestone - The Castle Hayne Limestone of Eocene age is the most important hydrologic unit in North Carolina. It consists of limestone containing abundant casts and molds of mollusks which grades downward into calcareous sand. The depth to the top of the Castle Hayne ranges from about 150 feet below sea level in western Washington County to about 1,100 feet below sea leve1 in eastern Dare County (fig. 20). It ranges in thickness from about 100 feet in Washington County to more thain 600 feet in Hyde County (fig. 21).

The Castle Hayne Limestone is the principal source of water supply in Washington County and the northeastern part of Hyde County (Nelson, 1964, p. 20 and fig. 7). Yields of wells drawing from the Castle Hayne depend on the thickness of the formation penetrated. Yields of several hundred gallons per minute are readily obtained and the yields of individual we11s used to dewater the phosphate mine in Beaufort County exceed 2,000 $\mathrm{gal} / \mathrm{min}$.

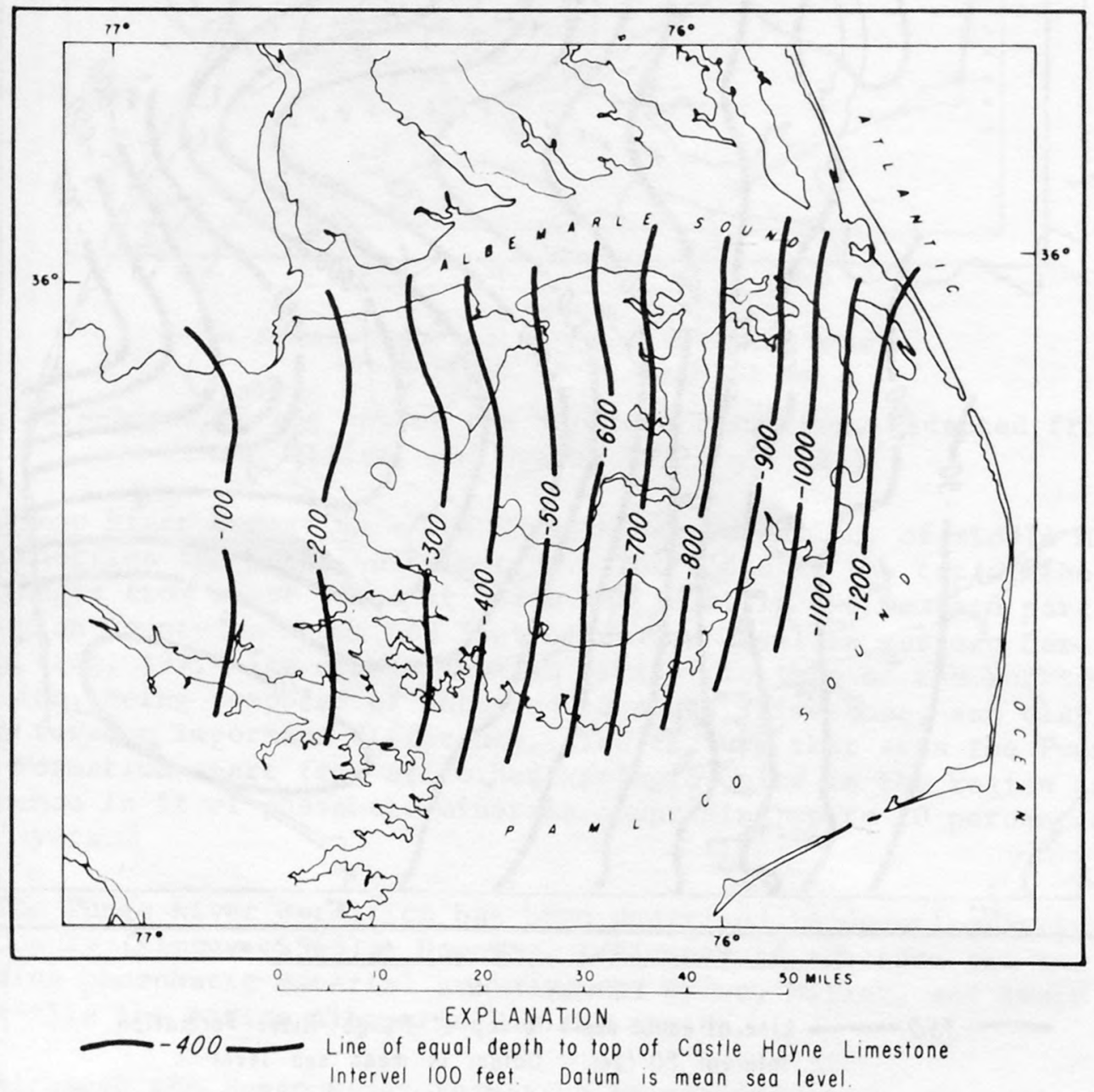

Figure 20.--Depth to the top of the Castle Hayne Limestone. (Adapted from Brown, Miller, and Swain, 1972, p1. 17.) 


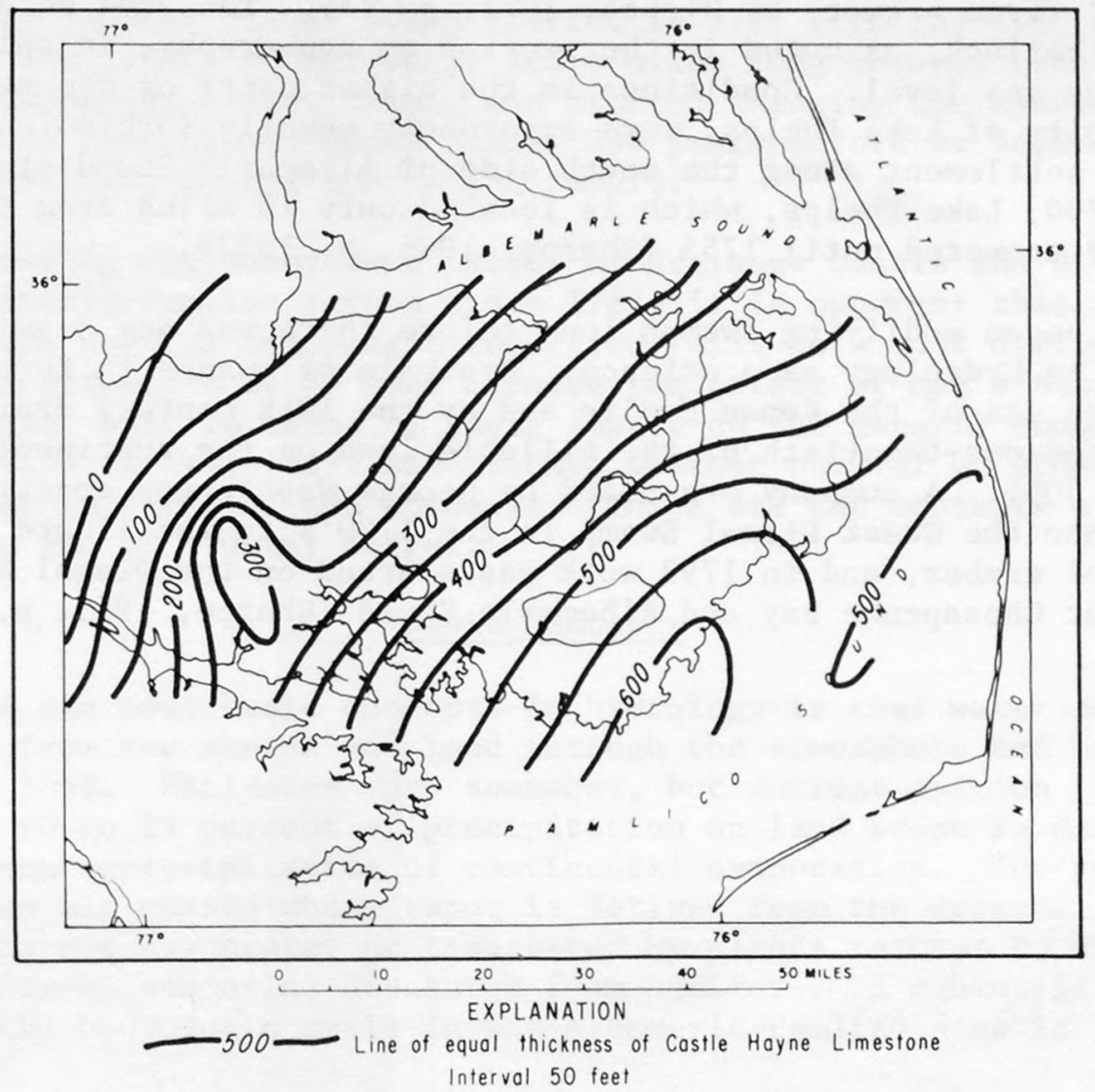

Figure 21.--Thickness of the Castle Hayne Limestone. (Adapted from Brown, Miller, and Swain, 1972, p1. 17.)

\section{NATURAL HYDROLOGIC CONDITIONS}

The preceding section was devoted to a description of those physical features of the Albemarle-Pamlico region that affect hydrologic conditions. We might view these features as the static parts of the hydrologic system. In this section we will consider how these features affect the occurrence and movement of water through the system under natural conditions.

It is appropriate to note at the beginning that the natural hydrologic conditions of swamps are very poorly known. The two principal reasons for this are (1) they are almost inaccessible (fig. 22) until penetrated by canals or roads which, of course, modify the conditions, and (2) most swamps were profoundly modified before knowledge of their hydro1ogy became of significant importance.

Relative to the inaccessible aspect of swamps, Governor Pollock in discussing action against the Indians in 1713 described the area between Lake Mattamuskeet and Roanoke Island as consisting of "lakes, quagmires, and cane swamps, and is, I believe, one of the greatest deserts in the wrrld, where it is almost impossible for white men to follow them the 
Indians T" (from a quote by Rights, 1971, p. 37). The area described by Governor Pollock, as noted in the section on topography, is only a few feet above sea level. Conditions in the higher parts of the swamp, in the vicinity of Lake Phelps, were apparently equally forbidding. Although settlement along the south side of Albemarle Sound started before 1700, Lake Phelps, which is located only 10 miles from the sound, was not discovered until 1755 (Sharpe, 1966, p. 1622).

Man began modifying swamps long before there was any significant interest in hydrology as a science. Drainage of swamps in Europe started before the era of the Roman Empire and by the 19th century drained swamps represented one-twentieth of the tillable land on the continent (Shaler, 1890, p. 309). A company organized by George Washington constructed canals into the Great Dismal Swamp in the $1700^{\prime}$ s to facilitate the removal of timber, and in 1793 work was started on the Disma1 Swamp Cana1 to connect Chesapeake Bay and Albemarle Sound (Sharpe, 1965, p. 1744).

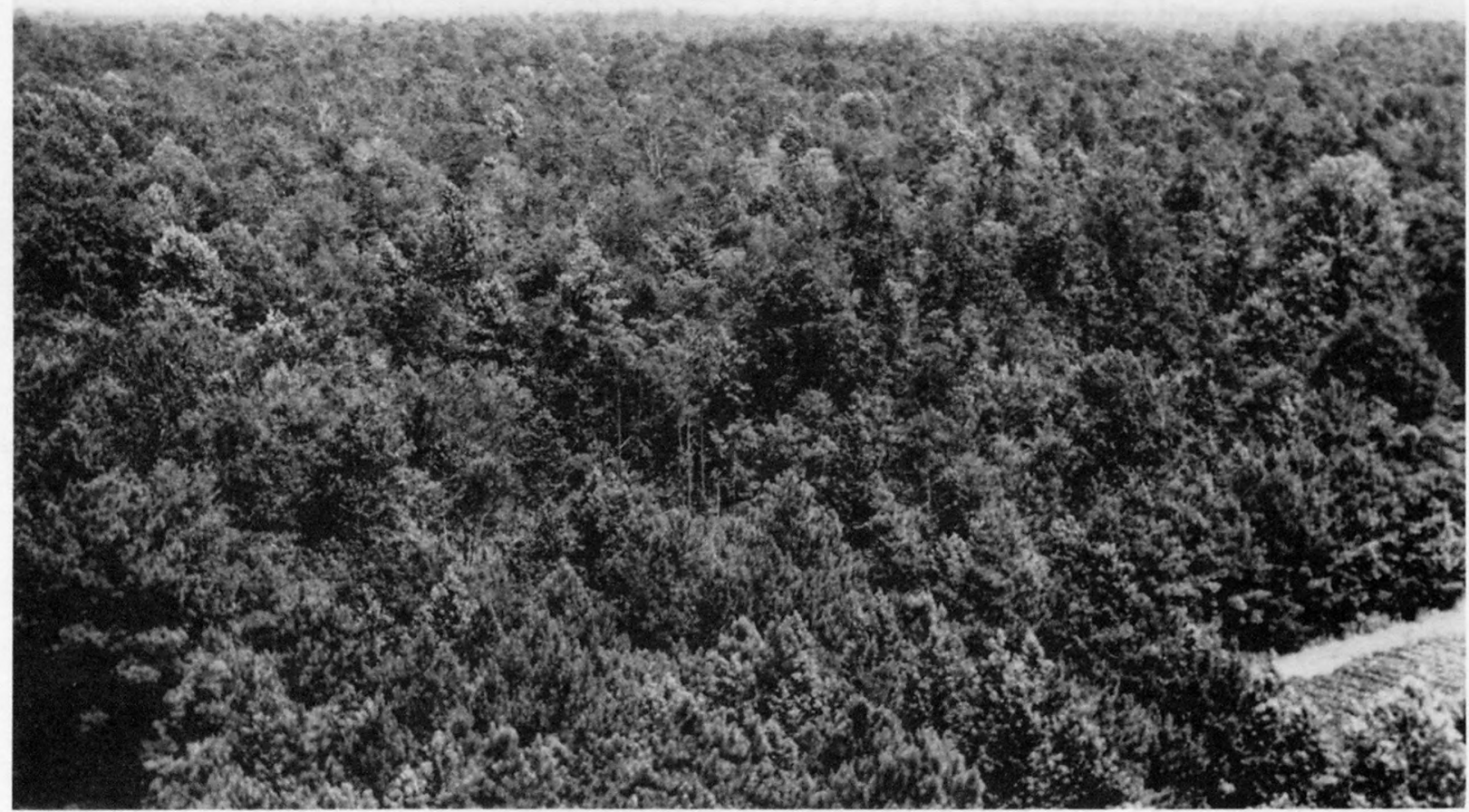

Figure 22.--Forest west of the Alligator River in Tyrre11 County. 
Modification of East Dismal Swamp started in 1787 with the construction of a canal 20 feet wide, 6 feet deep, and 6 miles long between Lake Phelps and the Scuppernong River. Thus, man started changing the hydrologic conditions in East Dismal Swamp nearly 200 years before he became concerned about the possible impact that might result.

Considering the hundreds of miles of drainage canals and ditches dug in the Albemarle-Pamlico region since 1787 , it is apparent that reconstructing the natural hydrologic conditions will be a most difficult task. However, an attempt must be made because the effect of man's activities are meaningful only in terms of their impact on the natural conditions. The discussion of hydrologic conditions, whether natural or otherwise, can best be done in terms of two concepts. These are the concepts of a hydrologic cycle and of a water budget.

\section{$\underline{\text { Basic Concepts }}$}

One of the most basic concepts in hydrology is that water continually circulates from the oceans and land through the atmosphere and back to the oceans and land. Estimates vary somewhat, but current opinion is that only about 10 to 15 percent of precipitation on 1 and areas is derived directly from reprecipitation of continental evaporation. The rest is derived from air masses whose vapor is derived from the oceans. Water on land that is not evaporated or transpired by plants returns to the oceans in streams or by submarine discharge from aquifers. A schematic representation of the hydrologic cycle in the Albemarle-Pamlico area is shown in figure 23.

In describing the hydrologic cycle, it is probably helpful to think in terms of wet and dry periods. During rains, water first filters into the ground and replenishes the soil moisture. Infiltration beyond this point moves downward to the water table as recharge to the zone of saturation. Because the depth to the water table is never great in swamps, recharge can rather quickly expand the zone of saturation up to the land surface. At this point water begins to pond on the surface and to start seeping slowly through and over the surface litter towards the nearest stream or the coast. Water moving over the land surface is termed overland runoff. As noted earlier, land-surface slopes in the Albemarle-Pamlico area are exceedingly flat and, under natural conditions, were composed of thick masses of leaves, twigs, and other debris. Thus overland runoff moved very slowly from the area and may, in fact, have continued for many days or weeks after heavy rains.

During dry periods the hydrologic system switches from a receiving to a discharging condition. Plants evaporate water in the process referred to as transpiration. At the same time water evaporates from the surfaces wet during the rain and from the soil and forest litter. If the dry period lasts long enough, the swamp surface becomes dry and the water lost by evaporation and transpiration is derived from the zone of saturation. This results in a decline in the water table. 

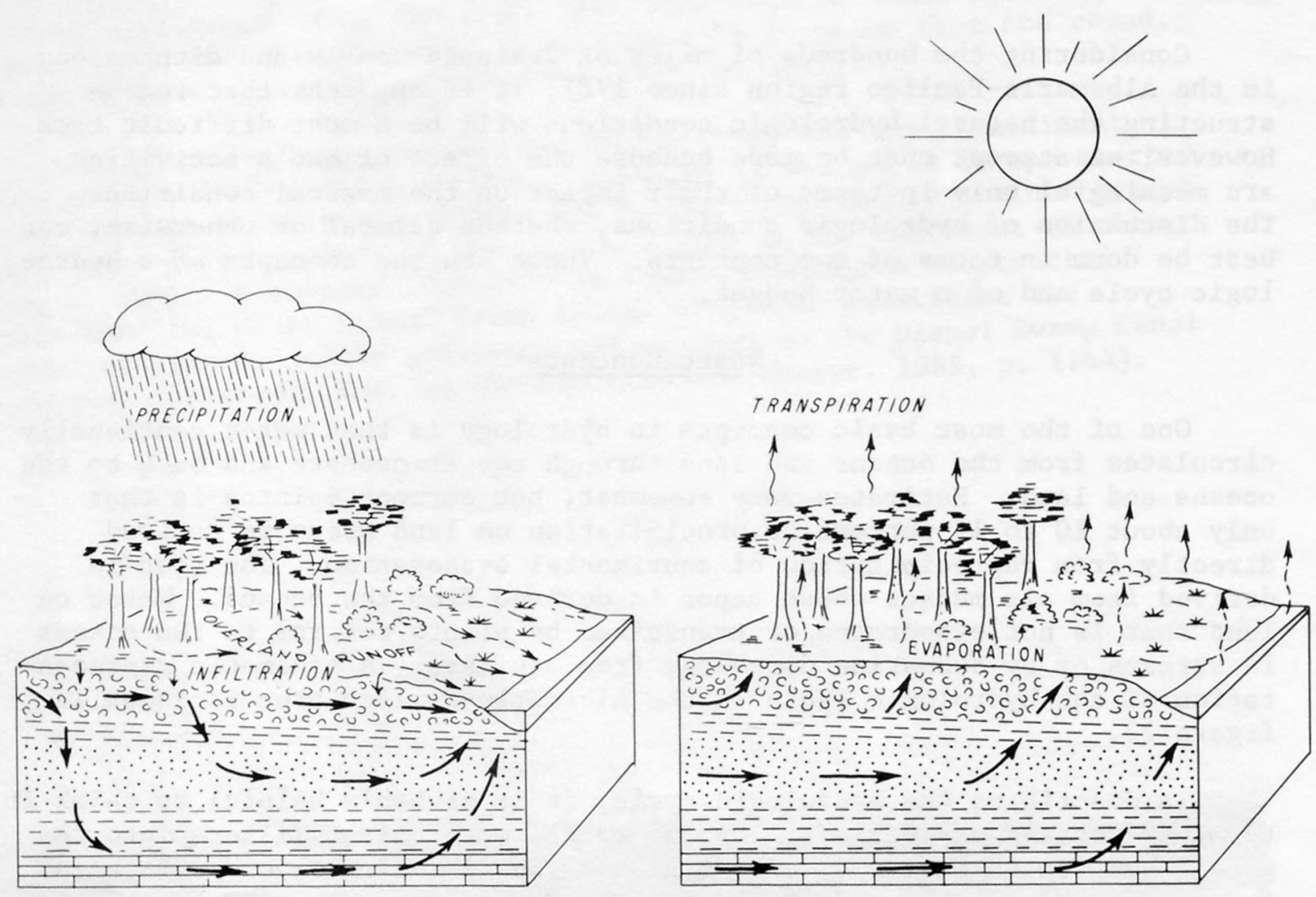

Figure 23.--"Wet" and "dry" aspects of the hydrologic cycle.

A basic aspect of the hydrologic cycle is that the water arriving in and the water leaving an area can be expressed in terms of a water budget which, over sufficiently long periods of time, balances. Thus, in the Albemarle-Pamlico region, both under natural conditions and under the conditions existing today, the water arriving as precipitation is balanced by the water leaving as evaporation, transpiration, and stream and aquifer discharge. In the following paragraphs we will attempt to assign values to each of the main items in the budget. These items, expressed in the form of an equation are:

$$
P=E T+G W D+O R
$$

in which $\mathrm{P}$ is precipitation, ET is evapotranspiration (evaporation plus transpiration), GWD is discharge from the area through aquifers, and OR is overland runoff. Each of these items will be discussed in the 
following sections. However, it is important to emphasize at this point that precipitation is the only one of these items actually measured in the region. Information related to the other items will have to be derived from other areas or developed from basic hydrologic principles.

\section{$\underline{\text { Precipitation }}$}

Precipitation is measured in or near the Albemarle-Pamlico region at 4 sites. These are referred to in publications of the National Weather Service as Belhaven, Manteo $2 \mathrm{WNW}, \underline{1}-\mathrm{New}$ Holland, and Plymouth 5E. Their

1/

2 WNW indicates the station is 2 miles west-northwest of Manteo.

locations are shown on figure 2. Mean annual precipitation on the area ranges from about 44 inches at the northeastern corner of the area to about 54 inches in southern Hyde County (Hardy, 1970, p. 18). The average for the region is about 51 inches. The longest precipitation record (56 years through 1973) is available for the New Holland station and is shown in the upper graph in figure 24. Precipitation at New Holland has ranged from a maximum of 69.61 inches in 1917 to a minimum of 31.47 inches in 1919. The average for the period of record is 52.37 inches.

Because droughts are a constant concern to farmers, it may be worthwhile to digress briefly at this point and consider this problem. One way to do this is to determine annual departures from the long-term average precipitation. If these departures are added or subtracted, depending on whether the precipitation exceeds or is less than the average, the result is as shown in the lower graph in figure 24. During periods when the graph is rising, such as in 1971 and 1972, precipitation exceeds the average. The periods of greatest concern, however, are those when the graph has a downward slope, as during most of the period from 1918 through 1927, because this shows periods when precipitation is below the average. Whether agriculture is adversely affected during these periods depends, of course, on whether the deficiencies in precipitation occur during the growing season or in other seasons.

\section{Evapotranspiration}

Evapotranspiration - or, more simply, ET - includes all moisture returned to the atmosphere in vapor form. It includes both evaporation from wet surfaces and the transpiration of water from plants. Because the conversion of water from liquid to vapor form requires a large amount of energy, solar radiation is the most important factor controlling ET. Other factors of less importance include wind speed and turbulence and the relative humidity of the air. 
AVERAGE ANNUAL PRECIPITATION $=52.37 \mathrm{IN}$.
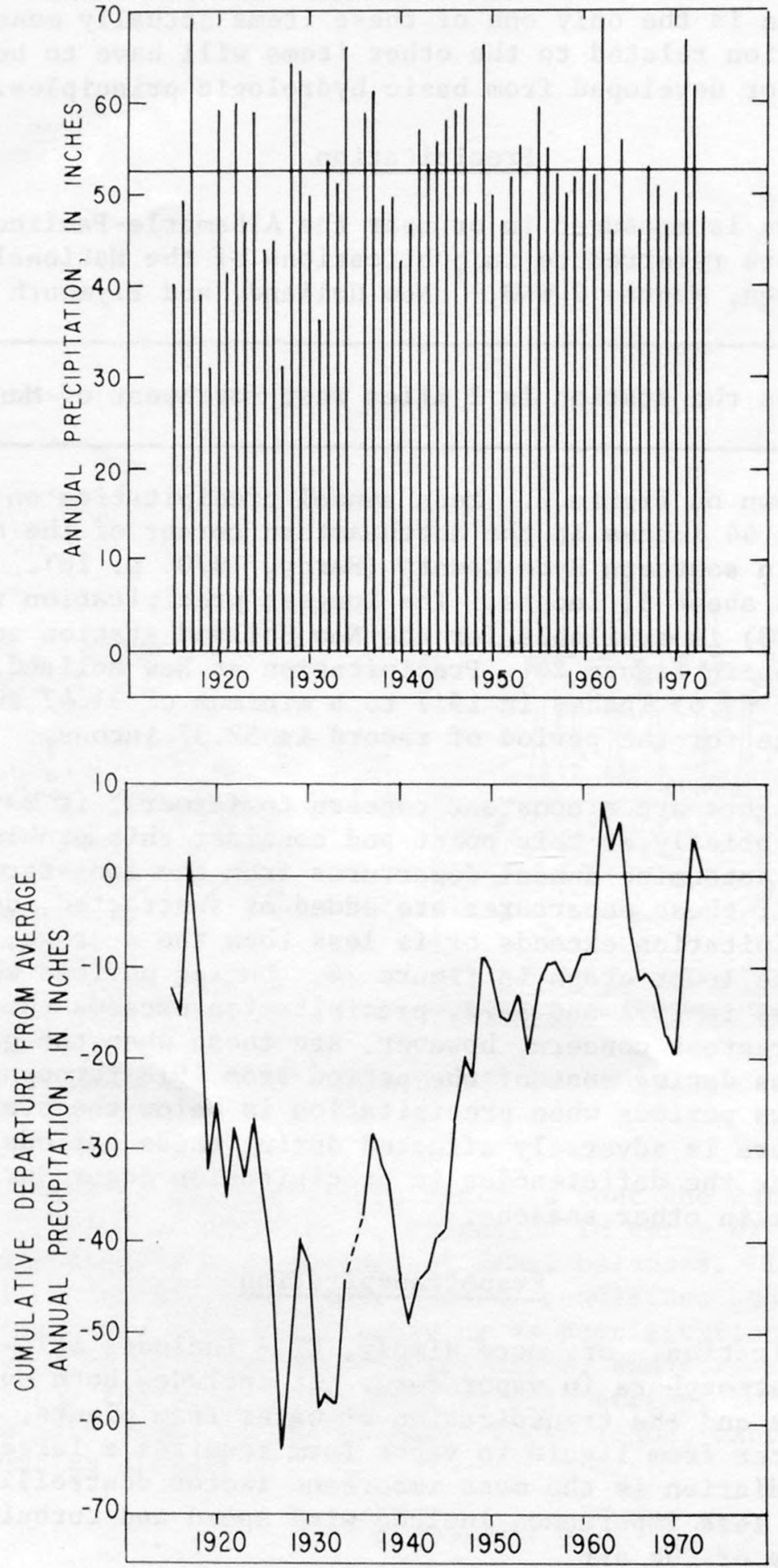

Figure 24.--Annual precipitation at New Holland and cumulative departures from the average (from records of the National Weather Service). 
Evapotranspiration rates also depend on the available moisture. Thus, the rate of evaporation of water from the soil declines relatively fast as soil moisture is depleted. Similarly, the transpiration rate of plants declines as soil moisture is depleted. Because of these factors it is common practice to differentiate between potential ET and actual ET. Potential ET is the maximum rate at which evapotranspiration will occur when there is no moisture deficiency. During such periods studies indicate that potential ET and actual ET are the same (Penman, 1963, p. 77-78). As the available moisture declines, the actual ET may become considerably less than the potential ET.

The existence of a swamp, especially one which contains thick accumulations of peat, suggests that periods of deficient moisture are rare. Therefore, except for notable droughts, actual ET should, for practical purposes, be the same as potential ET. But what is the potential ET? Because of difficulties in measuring both evaporation and transpiration, this question cannot be answered directly。

The principal means of measuring evaporation in the United States is through the use of National Weather Service Class A land pans. These are circular containers 4 feet in diameter, 10 inches deep, mounted on platforms 6 inches high. The evaporation of water from Class A pans has been measured for different periods of time at several places in the Coastal Plain, including the Hofmann Forest in Jones and Onslow Counties. If we can establish the relation between pan evaporation and potential ET it may be possible to estimate the ET in the Albemarle-Pamlico region under natural conditions. Studies by Penman and others indicate a close relationship between potential ET and evaporation from a free water surface (Ward, 1967, p。112). Numerous studies of lake evaporation indicate that it amounts to about 0.7 of pan evaporation. (For example, see Yonts, Giese, and Hubbard, 1973, table 3.) Pan evaporation data collected in the Hofmann Forest between 1961 and 1970 yields an average annual value of 51.24 inches. Applying the pan to lake coefficient of 0.7 we obtain an average annual lake evaporation of about 36 inches. This value should be reasonably representative of evaporation from the lakes in the Albemarle-Pamlico region but whether it represents equally we11 the ET from the natural swamp deserves further consideration.

Some hydrologists believe that the ET from a swamp may exceed the evaporation from a lake because the irregular surface of the vegetation increases the turbulence of the air moving over the swamp in comparison to that moving over the smooth surface of a lake (Ward, 1967, p. 89, 96-97). Penman (1963, p. 56) summarizes the results of studies in Washington which show that ET from "wet" soil planted with various low cover crops was about 10 percent higher than evaporation from open-water evaporation pans set in the ground. Hughes and McDonald (1966, p. 79) found that ET from tanks containing cattails (a common swamp vegetation) 
ranged from 0.78 to 1.00 of Class A pan evaporation. Because of the peaty nature of the soil in the Albemarle-Pamlico region, experiments in Germany which are described by Penman (1963, p. 77) are of interest. These experiments showed that ET from tanks containing peat was greater than from tanks containing clay and sand and the higher ET rates were maintained to greater moisture deficiencies. All tanks were planted with grass。

It is obviously not possible to determine conclusively at this time what the ET in the Albemarle-Pamlico region was before drainage of the area began. It is possible that it exceeded lake evaporation but was less than the evaporation from a Class A pan. However, pending the acquisition of better information, we will assume it to be the same as lake evaporation and adopt a coefficient of 0.7 in using pan evaporation to estimate the natural ET. Applying this coefficient to the pan evaporation data from Hofmann Forest we obtain an annual value for natural ET from the swamp of 36 inches.

Month1y variations in precipitation and evapotranspiration are shown in figure 25. The precipitation values shown on the graph are the normal monthly values established by the National Weather Service for the New Holland station. The evapotranspiration values were determined by multiplying pan evaporation data for the Hofmann Forest by 0.7 . It may be noted that precipitation exceeds evapotranspiration in all months except April and May.

\section{Ground-Water Discharge}

The general features of the sediments underlying the AlbemarlePamlico region were discussed in the preceding section on physical features of the region. It was noted there that three of the sedimentary units are important sources of water supplies. These are the Quaternary sediments that underlie the land surface, the Yorktown Formation, and the Castle Hayne Limestone. These units are hydrologically important because they are capable of transmitting significant quantities of water. Such units are referred to as aquifers. In the following paragraphs we will consider the functioning of these aquifers as a part of the hydrologic system.

First, however, we should note that in the two preceding sections we have discussed the water coming into the region as precipitation and the water leaving the region as a result of evaporation and transpiration. In this and the following section on overland runoff we will attempt to account for that part of the precipitation that is not lost through evapotranspiration. A part of this water moves out of the region through the ground-water system and, in order to estimate the amount, we must first estimate the hydraulic gradients under which the water moved and the hydraulic characteristics of the aquifers. We will first consider the Quaternary aquifer. 


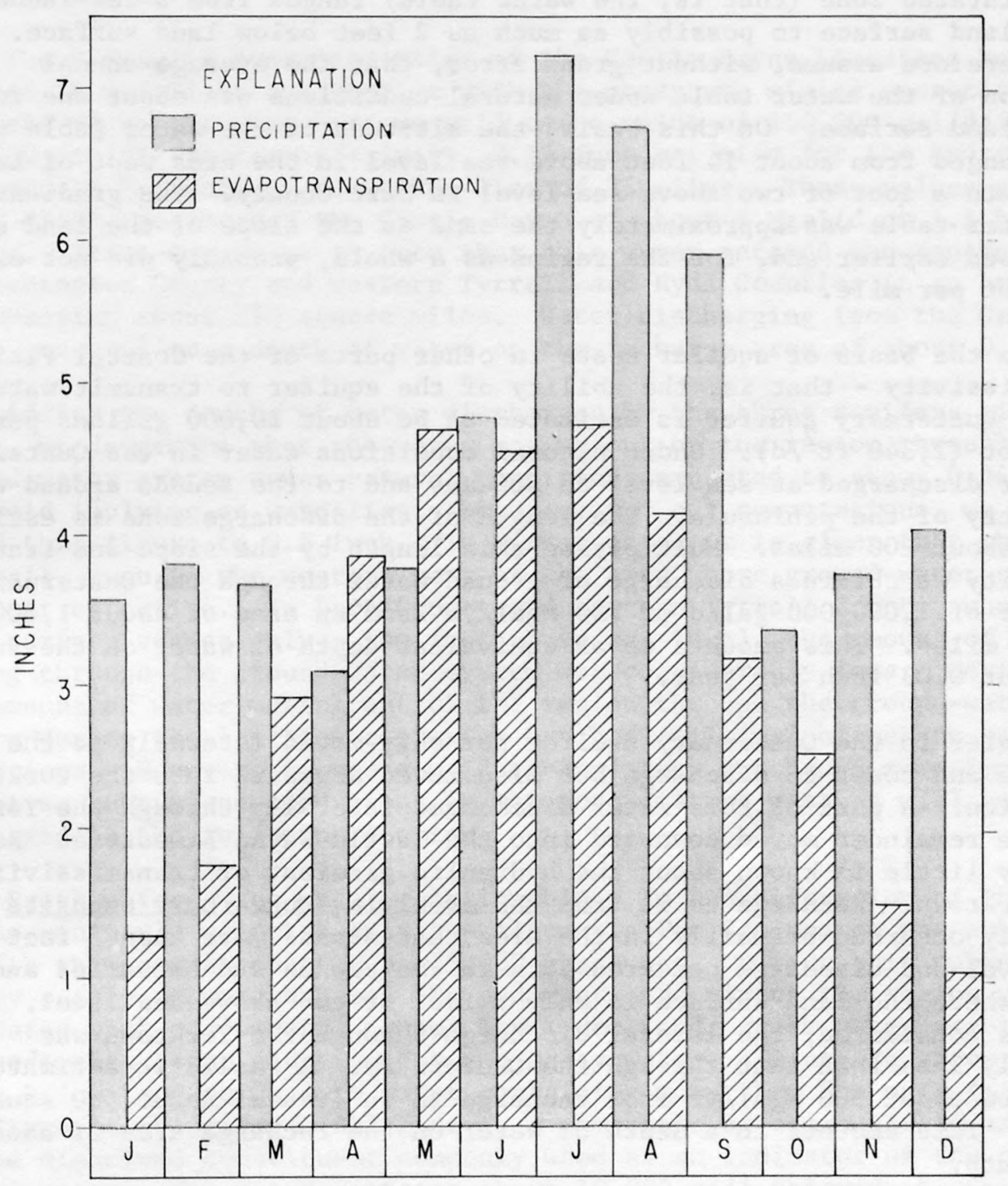

Figure 25.--Monthly precipitation at New Holland and evapotranspiration based on pan evaporation data from the Hofmann Forest. 
As noted earlier, peat can form only in wet areas. Thus, under natural conditions the underlying sediments were saturated with water and water stood to varying depths above the land surface throughout much of the year. At times when evapotranspiration exceeded precipitation ( $f i g$. $25)$, the surface remained wet through the capillary rise of water from the underlying zone of saturation. Under natural conditions, the top of the saturated zone (that is, the water table) ranged from a few inches above 1 and surface to possibly as much as 2 feet below land surface. We may therefore assume, without great error, that the average annual position of the water table under natural conditions was about one foot below land surface. On this basis, the altitude of the water table would have ranged from about 14 feet above sea level in the area west of Lake Phelps to a foot or two above sea level in Dare County. The gradient of the water table was approximately the same as the slope of the land surface discussed earlier and, for the region as a whole, probably did not exceed one foot per mile.

On the basis of aquifer tests in other parts of the Coastal Plain the transmissivity - that is, the ability of the aquifer to transmit water of the Quaternary aquifer is estimated to be about 10,000 gallons per day per foot $\left(1,340 \mathrm{ft}^{2} / \mathrm{d}\right)$. Under natural conditions water in the Quaternary aquifer discharged at sea level to streams and to the sounds around the periphery of the peninsula. The length of the discharge zone is estimated to be about 200 miles. Multiplying this length by the slope and transmissivity we obtain a discharge of ground water through the Quaternary aquifer of 2,000,000 gal/d or $730 \mathrm{Mgal} / \mathrm{yr}$ from an area of about 1,600 square miles. This amounts to an equivalent depth of water on the surface of about 0.03 inch per year.

Water in the Quaternary aquifer not only moved laterally to the streams and coast to discharge but also moved downward into the Yorktown Formation. A part of this water discharged laterally through the Yorktown and the remainder moved downward into the Castle Hayne Limestone. Re1atively little is known about the hydraulic gradient or transmissivity of the Yorktown. Recharge to it from the overlying Quaternary deposits probably occurred primarily in the area that stands more than 5 feet above sea level and discharge occurred both in the sounds and estuaries and in areas where the land surface is only a foot or two above sea leve1. A11 factors considered, the lateral discharge through the Yorktown was probably less than that through the Quaternary. A realistic estimate might be about $500 \mathrm{Mgal} / \mathrm{yr}$ from recharge in an area of about 500 square miles. This amounts to a depth of water on the recharge area of about 0.06 inch.

Relative to the Castle Hayne, figure 35 shows the height above sea level to which water in the aquifer would rise in June 1965 , prior to the start of large withdrawals at the phosphate mine in Beaufort County. This map probably approximates conditions that existed in the area under natural conditions. Because of the substantial depth to the top of the Castle Hayne (fig。20) and the presence of extensive clay layers in the overlying formations, recharge could occur only in the western part of 
the region where the altitude of the water table was between 5 and 10 feet above sea level or higher. Comparison of figure 35 with the topographic map in figure 9 suggests a loss of about 5 feet of head as the water moved from the water table to the Castle Hayne. Discharge of water from the Castle Hayne occurred in Albemarle Sound, the Pamlico and Pungo Rivers, and into the overlying aquifers in the low lying central and eastern parts of the area.

The hydraulic characteristics of the Castle Hayne Limestone have been studied in detail in conjunction with the phosphate mining operation. For purposes of computation here we will use a value of 150,000 gal/d/ft $\left(20,000 \mathrm{ft}^{2} / \mathrm{d}\right)$ for transmissivity, 0.75 foot per mile for the hydraulic gradent, and an "effective" discharge line of 35 miles. These values give a daily discharge through the Castle Hayne of about $4 \mathrm{Mgal} / \mathrm{d}$ or $1.5 \mathrm{billion}$ gal/yr. It is important to note that this water entered the aquifer only in Washington County and western Tyrrel1 and Hyde Counties in an area encompassing about 350 square miles. Water discharging from the Castle Hayne amounted to a depth of water on the recharge area of about 0.25 inch.

Adding the depths of water discharged by the three aquifers given above, we determine that the water moving out of the region through the ground-water system under natural conditions amounted to about 0.34 inch. To avoid implying an unrealistic accuracy for our computations, we will round this figure to $0.5 \mathrm{inch}$. In either case, it is clear that the value is sma11, even in the western part of the area where ground-water recharge was most effective. In Dare County and eastern Tyrre11 County, where the 1 and surface stands only a few feet above sea level, the amount of water moving through the ground-water system was considerably less. Certainly the amount of water moving out of the region through the ground-water system during the last few centuries has had a minimal effect on surface conditions. However, it was considerably larger and had a more important effect on subsurface conditions in the more distant past as will be discussed in the following section.

Fresh water - sea water relationship - In the discussion of the origin of the peninsula we noted that the Albemarle-Pamlico region was submerged beneath the sea as recently as 75,000 years ago. During this submergence we may safely assume that all the sediments underlying the region were saturated with sea water. As sea level declined, fresh water seeping into the sediments began flushing out the salty water. Figure 26 shows the depth below land surface to water containing more than $250 \mathrm{mg} / 1$ (milligrams per litre) of chloride. (Chloride is a component of common table salt and is the dissolved constituent commonly used as an indicator of the presence of sea water. Sea water contains about $19,000 \mathrm{mg} / 1$ chloride。) Sea water has been almost completely flushed from the west-central part of the region to depths of more than 400 feet. The depths are progressively less to the north, east, and south; being less than 100 feet along the Alligator River and in western Dare County.

Because of its higher content of dissolved minerals, sea water is slightly heavier (denser) than fresh water. Their differences in density 


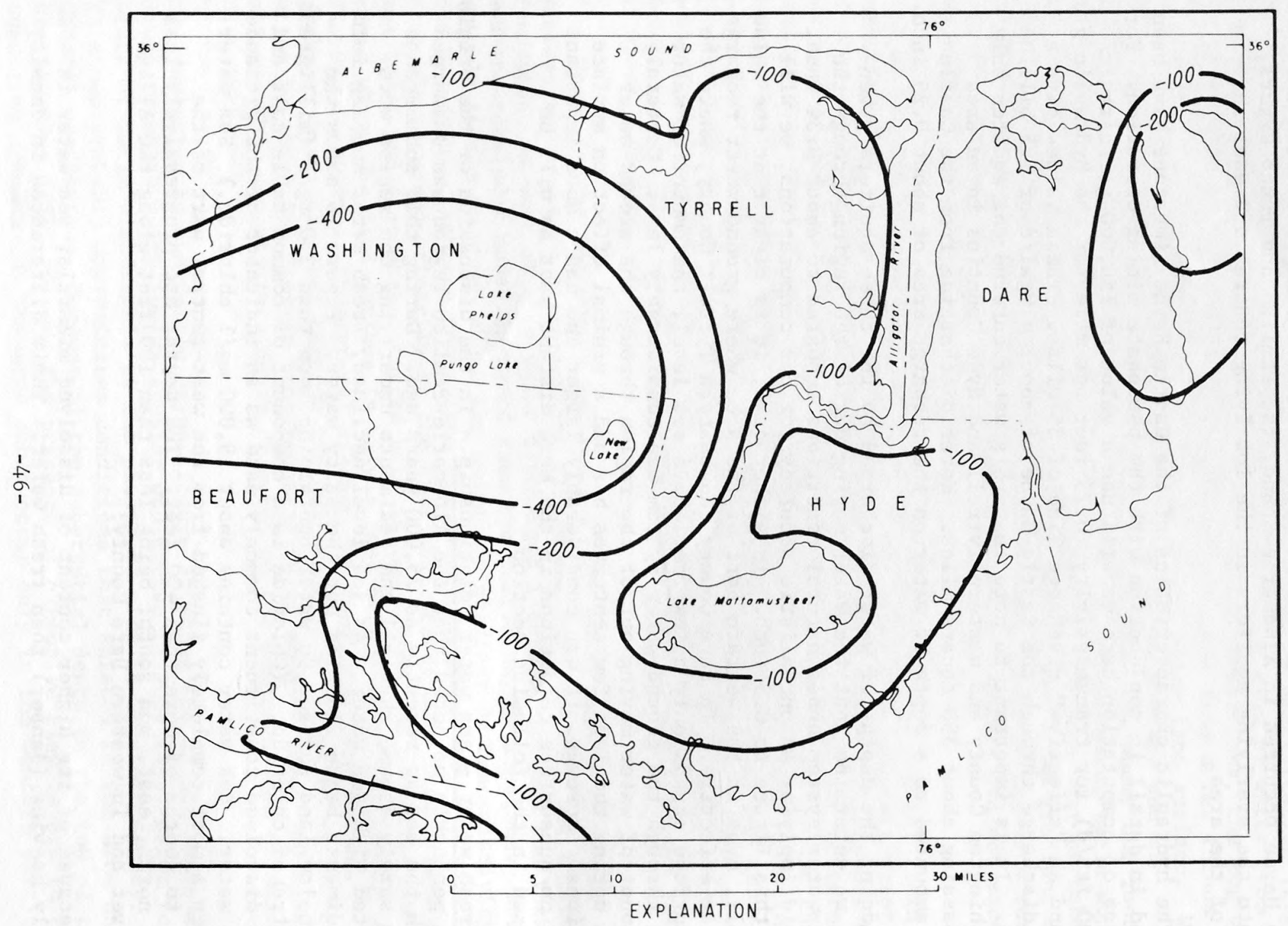

- Line of equal depth to water containing more than 250 milligrams per litre of chloride. Interval 100 feet. Datum is land surface.

Figure 26.--Depth to salty ground water. 
are such that about 41 feet of fresh water are required to balance 40 feet of sea water. In coastal areas, therefore, fresh water floats on sea water and, under idealized conditions, fresh water will occur to a depth below sea level equal to 40 times the height of the fresh water head above sea leve1. Now, referring to figure 35 we see that the water leve 1 in the Castle Hayne Limestone in June 1965 stood about 5 feet above sea level in the area between Lake Phelps and New Lake. Using the 40 to 1 ratio, sea water should occur at a depth of about 200 feet in this area. However, figure 26 shows that the depth to water containing only a fraction of the salinity of sea water is greater than 400 feet. The additional depth to undiluted sea water is not known but is surely more than a few hundred feet. In other words, fresh water occurs to much greater depths than the fresh-water heads would indicate. This suggests that the conditions in the past were more favorable for flushing the salty water out of the sediments than they are now.

The rate of flushing is directly related to the amount of fresh water moving through the sediments which, in turn, is controlled by the hydraulic gradient. With this in mind and referring back to figure 7, we can speculate that more favorable conditions for flushing existed when sea level was lower. The reason for this is that hydraulic gradients are controlled by the distance between the water table and sea level. As sea level declined, this distance increased and the rate of movement of fresh water also increased. The increased movement of fresh water through the groundwater system doubtless also caused a decline in the water table but this decline was surely always less than the decline in sea level. Thus, conditions were most favorable for flushing when sea level was at its maximum low level about 15,000 years ago.

Flushing of salty water continued for some time after sea level began to rise, even though the hydraulic gradients were also decreasing. But, ultimately, as sea level approached its present level the water table approached land surface, leading to the development of swampy conditions. (See the section on origin of the peat.) From this point on the hydraulic gradients decreased more or less in unison with the rise in sea level, and ultimately reached the point at which flushing not only stopped but sea water started to readvance into the sediments. The present great depth to salty water in the Albemarle-Pamlico region indicates that the system is out of balance with respect to present sea level. In other words, sea water should be much closer to land surface than it is so that when man first arrived in the area, sea water was actively advancing into the sediments and gradually displacing the fresh water. Most of man's actions since have tended to the increase the rate of advance.

Before leaving the discussion of the fresh water-sea water relationship it might be worthwhile to mention the conditions in the Roanoke Island-Croatan Sound area. As shown in figure 26, fresh water occurs in that area to a depth of 200 feet. An intensive study of the geologic and hydrologic conditions of this area and the adjoining area on the Outer Banks was made in 1972 by the State Division of Ground Water in the search for fresh-water supplies for the Dare County beach area (Peek, Register, 
and Nelson, 1972). The results of that study indicate that the principal recharge area is on Roanoke Island. Water-level measurements and waterquality samples obtained as a part of the study indicate that, except for the northern part of the island, the depth to salty water is greater than the present fresh-water heads can maintain.

\section{Overland Runoff}

Returning to the discussion of the water budget, the last item is overland runoff - that is, water which flows over the land surface to streams, lakes, and the coast. Overland runoff in more inland areas such as the Piedmont and Inner Coastal Plain is readily apparent from stream flooding that occurs during intense rain storms. The amount of water reaching streams by overland flow can be fairly closely estimated at sites where stream-gaging stations are operated. The Geological Survey streamflow-data-collection program in North Carolina includes 168 such stations at the present time (1974). However, none of these stations are located on the Outer Coastal Plain in the area seaward of the Suffolk Scarp. There are several reasons for this, including problems presented by slow velocities and the tidal fluctuations common in Outer Coastal Plain streams. Therefore, in attempting to balance the water budget in the Albemarle-Pamlico area, it is necessary either to utilize streamflow data collected in areas to the west or to estimate overland runoff as the difference between precipitation and the other water-budget items.

Because of the lack of streamflow data for the area, either under natural conditions or under the present conditions of intensive canal and ditch drainage, we will estimate overland runoff under natural conditions as the residual in the water budget. Thus, summarizing the items in the water budget discussed in the preceding sections, we obtain:

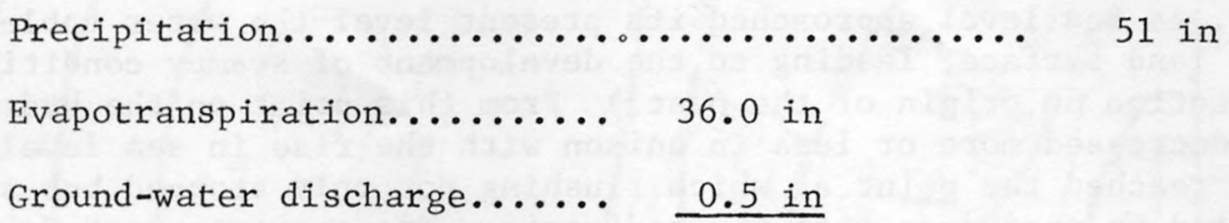

Subtota1

36.5 in

Overland runoff (by difference)

14.5 in

We will consider in a later section how the overland runoff of 14.5 inches is affected by agricultural drainage.

We noted in the section on streams and lakes that the natural (surface) drainage system in the area was limited to a few short streams around the periphery of the area. How then did the overland runoff leave the area? An attempt to answer this question is shown in figure 27. This figure shows the principal natural streams and the major drainage divides. It also shows, through the use of arrows, the general paths followed by water moving over the land surface. We 


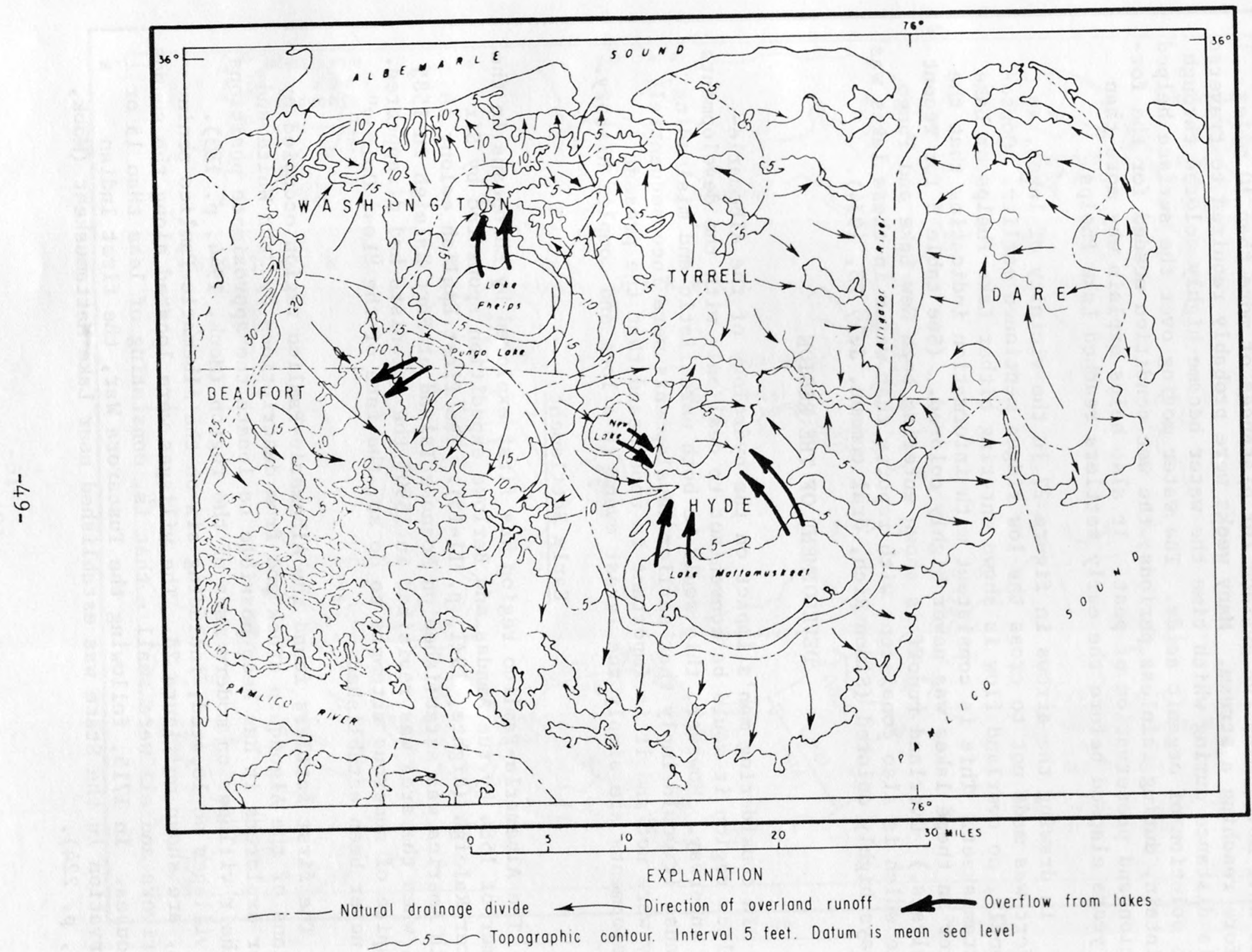

Figure 27.--Paths taken by overland runoff. 
visualize that the water following the paths indicated by the arrows seeped slowly over and through the thick litter that formed the surface of the swamp. In places, as in the area east of Lake Phelps, the water must have moved over the surface for distances of more than 10 miles before reaching a stream. Many weeks were probably required to traverse this distance during which time the water became highly colored through the solution of organic acids. The water moving over the surface helped maintain, during rainless periods, the wet condition needed for the formation and preservation of peat. It also helps explain why more than 55 years elapsed before the early settlers reached Lake Phelps.

In drawing the arrows in figure 27 in the vicinity of 1 akes, an effort was made not to cross the low ridges mentioned earlier. Consequently, no overland flow is shown entering either Lake Phelps or Lake Mattamuskeet. This is consistent with information indicating that the water in these lakes was never highly colored. (See table 3 for recent analyses。) Overland runoff is shown entering both New Lake and Pungo Lake which is also consistent with reports that water in these lakes was always highly colored (Simon Rich, oral commun, July 23, 1974).

\section{DEVELOPMENT OF THE REGION}

In considering man's impact on the hydrology of the AlbemarlePamlico region it would be convenient to deal only with the developments now underway. However, this would be both unrealistic and misleading because it would imply that earlier developments were inconsequential. They were not and it is important to understand that the present developments are simply the latest event in a long and complex history.

\section{Early Settlement}

The Albemarle-Pamlico region was first explored by Europeans in the summer of 1584 by the Amadas and Barlowe expedition sponsored by Sir Walter Raleigh (Rights, 1971, p. 11-15). The first English colony in North America was established on Roanoke Island at Fort Raleigh in 1585 but, when the area was revisited in 1590, the colonists had disappeared. In spite of numerous attempts to do so, the fate of the "Lost Colony" has never been established.

The first settlers found the Albemarle-Pamlico region occupied by Indians of the Algonquin stock and from descriptions by John White and other explorers it has been possible to locate the approximate positions of their villages on modern maps of the region (Mook, 1944, p. 183). The villages so located, including six on the Albemarle-Pamlico peninsula, are shown on figure 28. The villages were located along the sounds and rivers and all were small - that is, consisting of less than 15 or 20 houses. In 1715, following the Tuscarora War, the first Indian reservation in the State was established near Lake Mattamuskeet (Mook, 1944, p。224). 


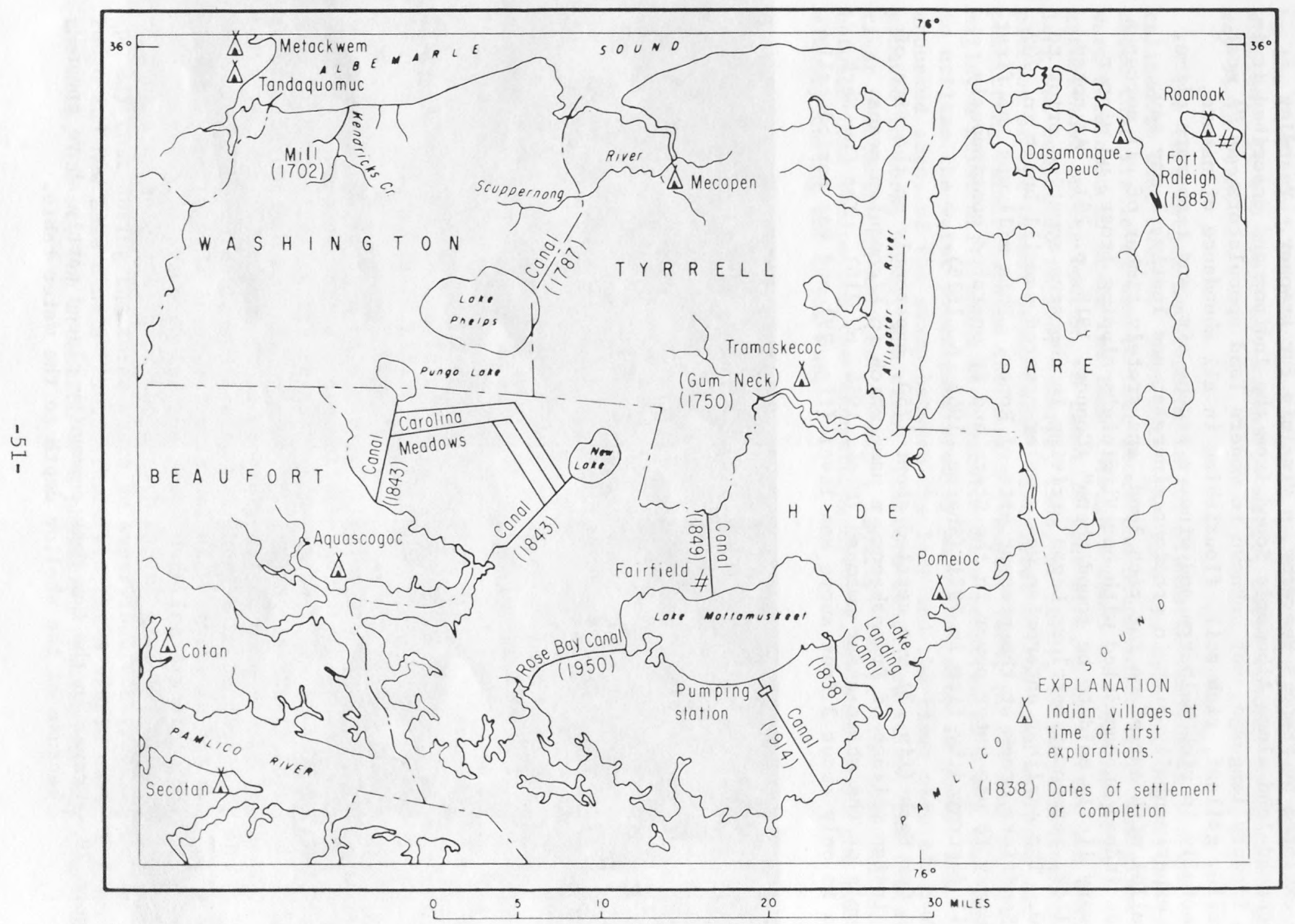

Figure 28.--Early settlements and man-made works. 
There is no record of visits to the area from 1590 to 1654 when it was explored by Francis Yeardley, a Virginia fur trapper. Yeardley purchased 1 and along Albemarle Sound from the Indians and described it in the flowery language, not unknown to modern land speculators, as "A most fertile, gallant, rich soil, flourishing in al1 abundance of nature, especially in rich mulberry and vine, a serene air, and temperate clime, and experimentally rich in precious minerals; and lastly, I may say, parallel with any place for rich land, and stately timber of all sorts; a place indeed unacquainted with our Virginia's nipping frost, no winter, or very little cold to be found there" (Connor, 1919, p. 23). As noted earlier, permanent settlers began arriving in the area sometime prior to 1700. The earliest enterprise was a water-powered sawmil1 built in 1702 on Kendricks Creek at the present site of Roper. This mill was the first industry to use water power in the State and it operated continuously until destroyed by fire in 1921 (Sharpe, 1966, p. 1615).

Gum Neck (fig. 2) was settled about 1750, apparently on the site of the Indian village of Tramaskecoc, a name which in Algonquian means "People of the white-cedar swamps" (Mook, 1944, p. 216). The Gum Neck area is only about 3 feet above sea level (fig. 29) and was periodica11y

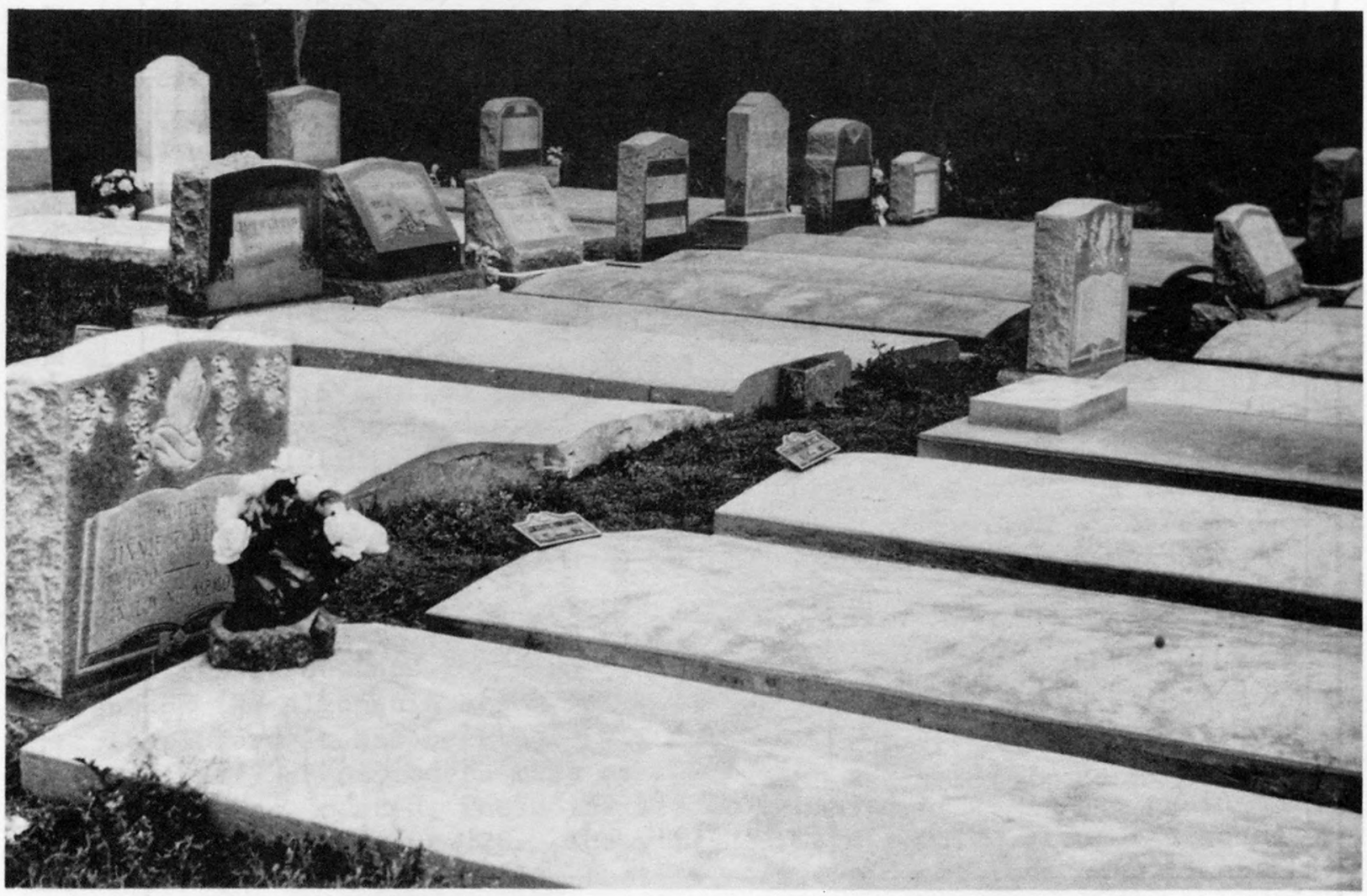

Figure 29.--Graves in the Gum Neck community placed partly above ground because of the shallow depth to the water table. 
inundated by storm-driven tides on the Alligator River until the completion by the U. S. Soil Conservation Service in 1968 of a dike and pumping station. It was isolated, except by water, until reached by State highway 94 in 1933 .

The first major development in the Albemarle-Pamlico region was related to Lake Phelps. Soon after the lake was discovered a survey indicated that its level was 14 feet above the Scuppernong River and plans were developed to drain the lake through a canal so farms could be established on its bottom. A canal 20 feet wide, 6 feet deep, and 6 miles long was completed in 1787 (Sharpe, 1966, p. 1623), 17 years before completion of the Dismal Swamp Canal. The level of the lake was lowered, permitting farming around the margin (Vaughn, 1884, p. 27) and two sawmills, a grist mil1, and a rice machine were constructed along the canal to utilize the water power generated by an 8 foot drop in head. Ten thousand acres of the swamp between the lake and the river were cleared and planted in corn, wheat, and rice. Visitors described it as "the finest river plantation in America" (Sharpe, 1966, p. 1624)。The plantations between Lake Phelps and the Scuppernong River fiourished until the end of slavery during the Civil War.

In an effort to encourage development of the Albemarle-Pamlico region, the State Literary Board (a board established to promote public education) assigned $\$ 200,000$ in the late $1830^{\prime}$ s to the construction of drainage canals for Mattamuskeet, Pungo, and New Lakes. The Mattamuskeet Canal (now known as Lake Landing Canal) was completed in 1838 and extended from the southeast corner of the lake 5 miles to Pamlico Sound. A second canal was dug from Lake Mattamuskeet northward to the Alligator River in 1849 to provide drainage and water transportation for the Fairfield area.

The drainage canals for New Lake and Pungo Lake were dug between 1839 and 1843 with the intention of lowering the levels of the lakes by 5 feet. The widths of the canals ranged from 25 feet for Pungo Lake to 30 feet for New Lake. Lateral canals 12 to 16 feet wide were spaced about a mile apart along the main canals to the extent that 70,000 acres were drained (Vaughn, 1884, p. 23). Lefler (1956, p. 363) indicates that the lake drainage project ". . did not work out satisfactorily and the State's investment was almost a total 1oss." Lefler presumably reached this conclusion because settlers did not take advantage of the newly drained land. The failure of the State to attract settlers to the area is not surprising because as Asimov (1968, p. 180) notes "Until 1880, malaria, which year in and year out has probably killed more people in the world than any other infectious disease, was thought to be caused by the bad air of swampy regions." To offset this belief Vaughan, in his pamphlet on the Albemarle Region prepared for the North Carolina Exposition of 1884, commented at some length on the health aspect of the region. He indicates (p. 23) that during the three years he supervised construction of the Pungo and New Lake canals ". . there was not a single case of fever on the work, nor was the attention of a physician required in any instance." 
The swamp forests from the time of the first settlements provided an important source of income and, beginning in the early 1800's, large quantities of shingles, barrel staves, and lumber were shipped by boat from docks on the Scuppernong River to East Coast and foreign ports。 In 1890, major lumbering operations were initiated with the establishment of the John L。 Roper Company at Lees Mill on Kendrick Creek. The settlement was given the name of Roper at that time. The Roper Company owned land extending across the peninsula from Albemarle Sound to the Pamlico River (Jim McMillan, oral commun, July 25, 1974). Logging camps were established in the interior of the swamp for year-around operation. Mules with pads on their feet called "snowshoes" were used to move the logs to the railroad built across the swamp from Roper.

In the early $1900^{\prime} \mathrm{s}$, the Roper Company and the Norfolk and Southern Land Company established the Carolina Meadows subdivision south of Lake Phelps and offered 80-acre tracts for sale. Canals were constructed as a part of this development but only a few tracts were sold and this, the second major attempt to settle the swamp, also failed.

Lake Mattamuskeet Development - Possibly the most ambitious development scheme undertaken in the region prior to the last few years was an attempt early in this century to farm the bottom of Lake Mattamuskeet. The shallow lakes in the Albemarle-Pamlico region have always seemed to be ideal sites for farms because they only required drainage, whereas the adjoining swamps required both drainage and the removal of vegetation. Lake Mattamuskeet, because of its area of nearly 67 square miles and almost flat bottom, has special appeal. However, in contrast to Lake Phelps and the other lakes, it has one serious defect - the position of its bottom two feet below sea level (table 2). Because of this, it must be drained with pumps and they must not fail for any significant period.

In 1913 a stock company was formed to drain and farm Lake Mattamuskeet. A pumping station consisting of four steam-powered pumps with a capacity of $1,250,000 \mathrm{gal} / \mathrm{min}$ or about $2,800 \mathrm{ft}^{3} / \mathrm{s}$ was constructed and a canal was dug from the south side of the lake seven miles to Pamlico Sound. Hundreds of miles of canals and ditches were dug on the bottom of the lake for drainage. Because of financial difficulties the original company sold its interests to a second company in 1917. The second company encountered the same difficulty in 1923 and was purchased in 1925 by August Heckscher, a New York millionaire.

Heckscher's New Holland Corporation controlled 48,000 acres, including the nearly 43,000 acres now occupied by the 1 ake and 5,000 acres of adjoining 1 and. An additional 51,000 acres of surrounding higher 1 and in private ownership were included in the Mattamuskeet Drainage District. Sometime during the Lake Mattamuskeet drainage project - references contain conflicting dates - a village, aptly named New Holland, including 
homes, businesses, and a 23-room hotel was built. The drained area also included 25 miles of graded road and 50 miles of railroad (Mary E. Harris, Raleigh News and Observer, June 2, 1963).

The maximum area under cultivation on the lake bottom was apparently 12,000 acres (Sharpe, 1966, p. 899) and was producing by 1928 bumper crops of grains and vegetables. However, pump breakdowns and agricultural pests began to take their toll and the project almost ended in 1931, but was continued until officially ended on February 13, 1933. Crops planted in 1933 were not harvested and the lake bottom, under terms of an agreement signed in 1915, reverted to state control.

After an expenditure of more than $\$ 17,000,000$ and several bumper crops, Lake Mattamuskeet again became a lake and the village of New Holland stood in two feet of water. The Federal government purchased the lake and some adjoining land in 1934 at the time of formation of the Mattamuskeet National Wildlife Refuge. The pumping station (fig. 30) was converted to a lodge and its smokestack to an observation tower and, since 1934, the level of the lake has been managed for the benefit of ducks and geese.

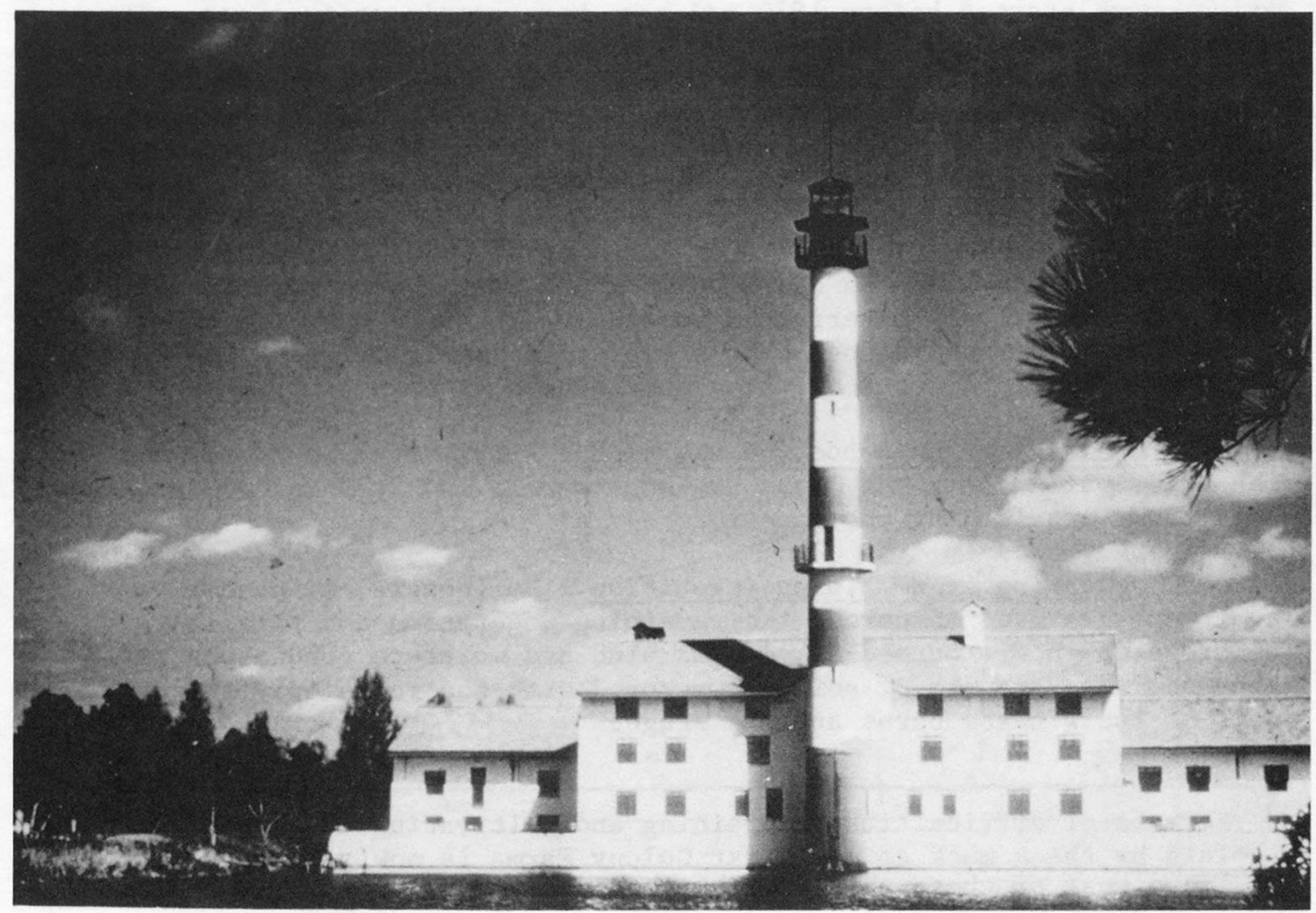

Figure 30.--Lake Mattamuskeet pumping station after its conversion to a lodge and the conversion of its smokestack to a lookout tower. (Photograph courtesy of Lake Mattamuskeet National Wildlife Refuge.) 
Large Corporate Farms - Efforts which started 3 centuries ago to fully develop the agricultural potential of the Albemarle-Pamlico region have finally come to fruition in the last few years. Three large undeveloped tracts totaling 414,500 acres or 648 square miles have been purchased and are in the process of being drained and cleared for intensive farming and livestock operations. The individual farms, in order of size, are: (1) First Colony Farms - 372,000 acres, (2) Mattamuskeet Farms - 35,000 acres, and (3) Shima-American Farms - 7,500 acres (Steve Berg, Raleigh News and Observer, May 12, 1974)。The areas controlled in 1974 by these farms are shown in figure 31.

As rapidly as economic, labor, and other conditions permit, all of these areas, except those immediately adjacent to tidewater, will be drained, cleared, and devoted to agricultural production. I The principal crops will be corn, wheat, and soy beans (fig. 32). In addition, large areas will be devoted to pastures and feed lots for cattle and swine. Ultimately, if present plans are realized, meat-packing and foodprocessing plants will be constructed in the region to utilize the farm products。

Preparing the land for cultivation is a major operation, as visitors to the area can readily observe. Extensive draining and clearing operations were started before 1970 and have been accelerating since. The steps in these operations cannot be done simultaneously but must be done in a certain order because of the swampy nature of the terrain (Robert Campbe11, oral commun. July 23, 1974). Steps in the operations are:

1. Construction of drainage canals - In areas not previously drained, major canals are spaced about a mile apart. Depending on the terrain, they are dug 10 to 15 feet deep and 15 to 25 feet wide at the top. All dirt is piled on one side where it serves as a road foundation and, where additional material is needed for the road bed, the canal may be dug both wider and deeper than normal. In low-1ying areas, collector ditches and field ditches are also constructed at this time.

2. Removal of pulpwood and saw timber - This step is facilitated by the roads built along the major drainage canals and by the somewhat dryer conditions provided by the canals.

3. Clearing of remaining vegetation - Bulldozers and other power equipment are used to uproot the remaining vegetation and pile it in windrows which are burned as soon as wind and moisture conditions permit. Because large amounts of soil are removed with the roots only the outer part of the windrow burns at this stage.

I Because of difficulties in draining and cultivating the areas underlain by thick muck soils, First Colony Farms is now planning to leave most of these areas in their natural state. (4-17-75) 


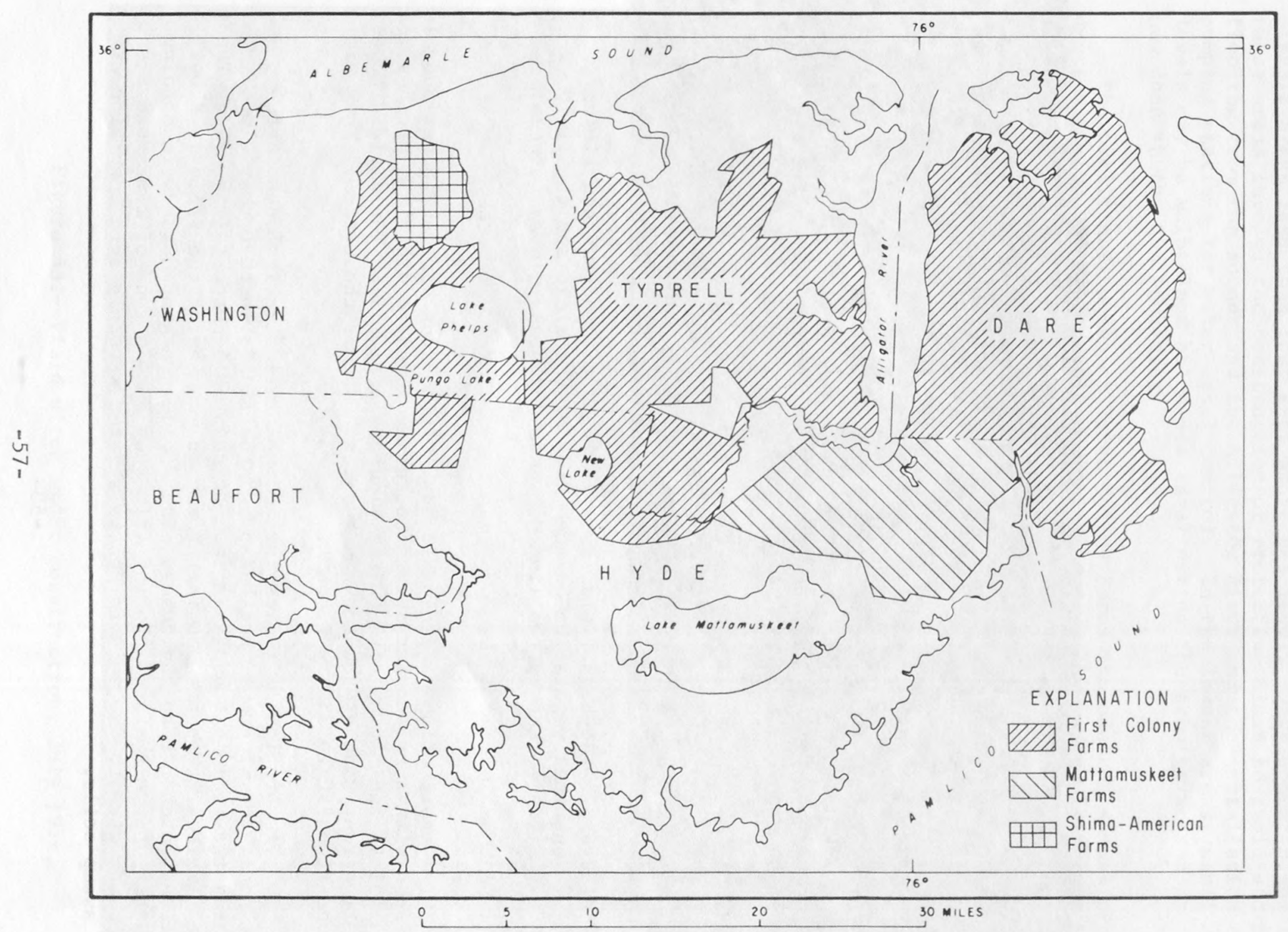

Figure 31.--Land owned by large corporate farms in 1974 . 


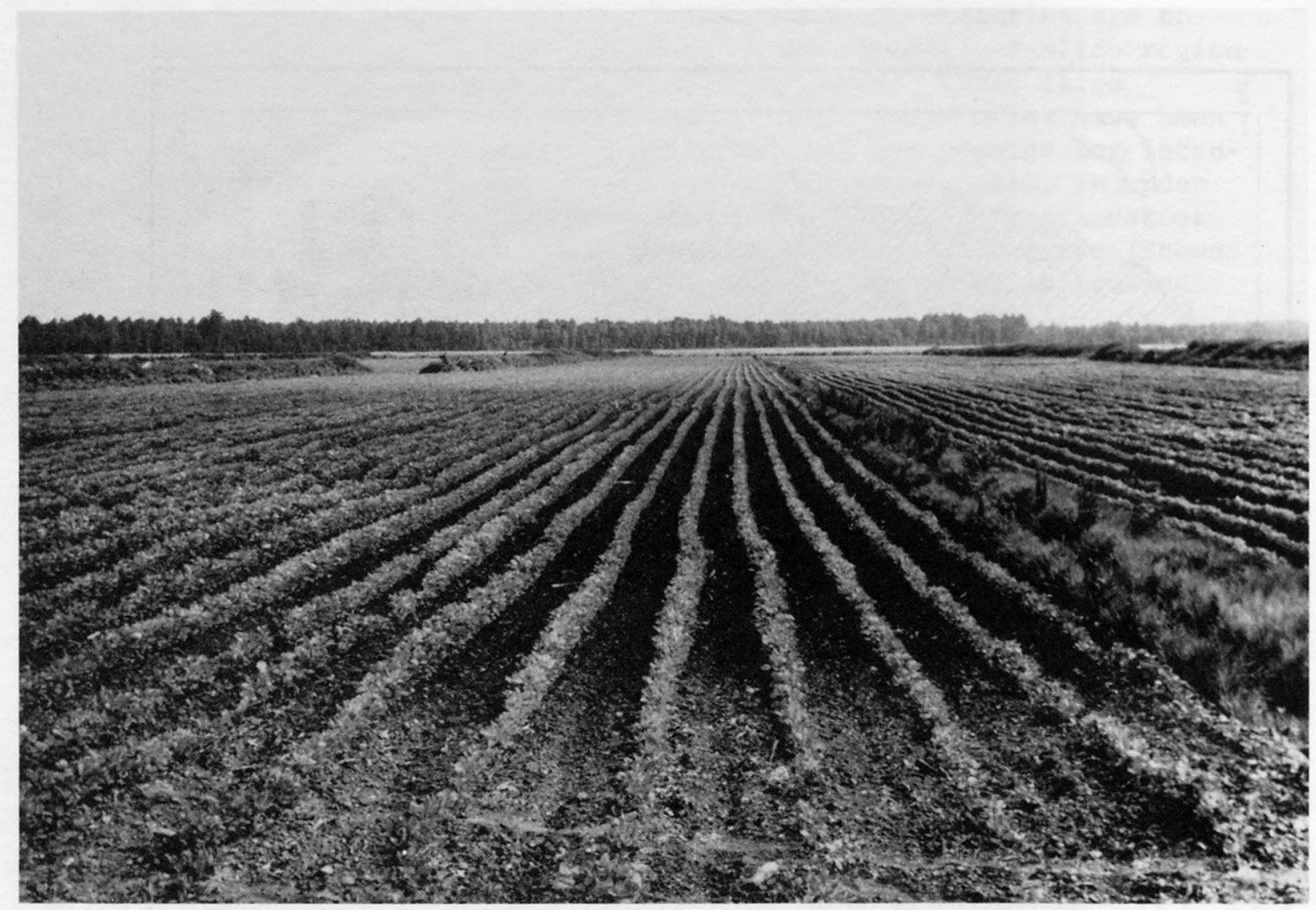

Figure 32.--Soybean fie1d, July 1974. Note windrows containing unburned vegetation on each side of the field and the field ditch marked by the line of weeds and grass midway between.

4. Construction of field ditches - If not dug earlier, power shovels equipped with a triangular shaped bucket are used to dig field ditches parallel to and midway between the windrows (fig. 33)。The field ditches are five feet wide at the top and one foot wide at the bottom. They are spaced from 260 to 330 feet apart.

5. Preparation of fields for crops - This step includes further burning of the windrows, and "shaping" the fields so that they slope towards the field ditches at a rate of about 0.5 percent (fig. 34). Thus, where field ditches are 330 feet apart the center of the field is about, 10 inches higher than the edges. The fields are shaped to avoid ponding of water on the surface. During this step 5 to 6 tons of limestone are added per acre to the soil to neutralize the strongly acid condition of the swamp soils. 
The 1 and owned by First Colony Farms and Mattamuskeet Farms includes sizable areas less than four feet above sea level. Development plans for these areas involve the construction of protective dikes to avoid storm flooding from the sounds and the Alligator River and the installation of pumping stations for water level control. In the lowest areas, canal levels may be maintained below sea level during the growing season as is now done in the Gum Neck area.

The preliminary plans of First Colony Farms include the annual production of 100,000 beef cattle and maintenance of a herd of 50,000 brood sows producing half a million swine for market each year. The animals will be in both pastures and feed lots. Animal wastes generated in feed lots will be collected and processed into fertilizer and spread on the crop and pasture land.

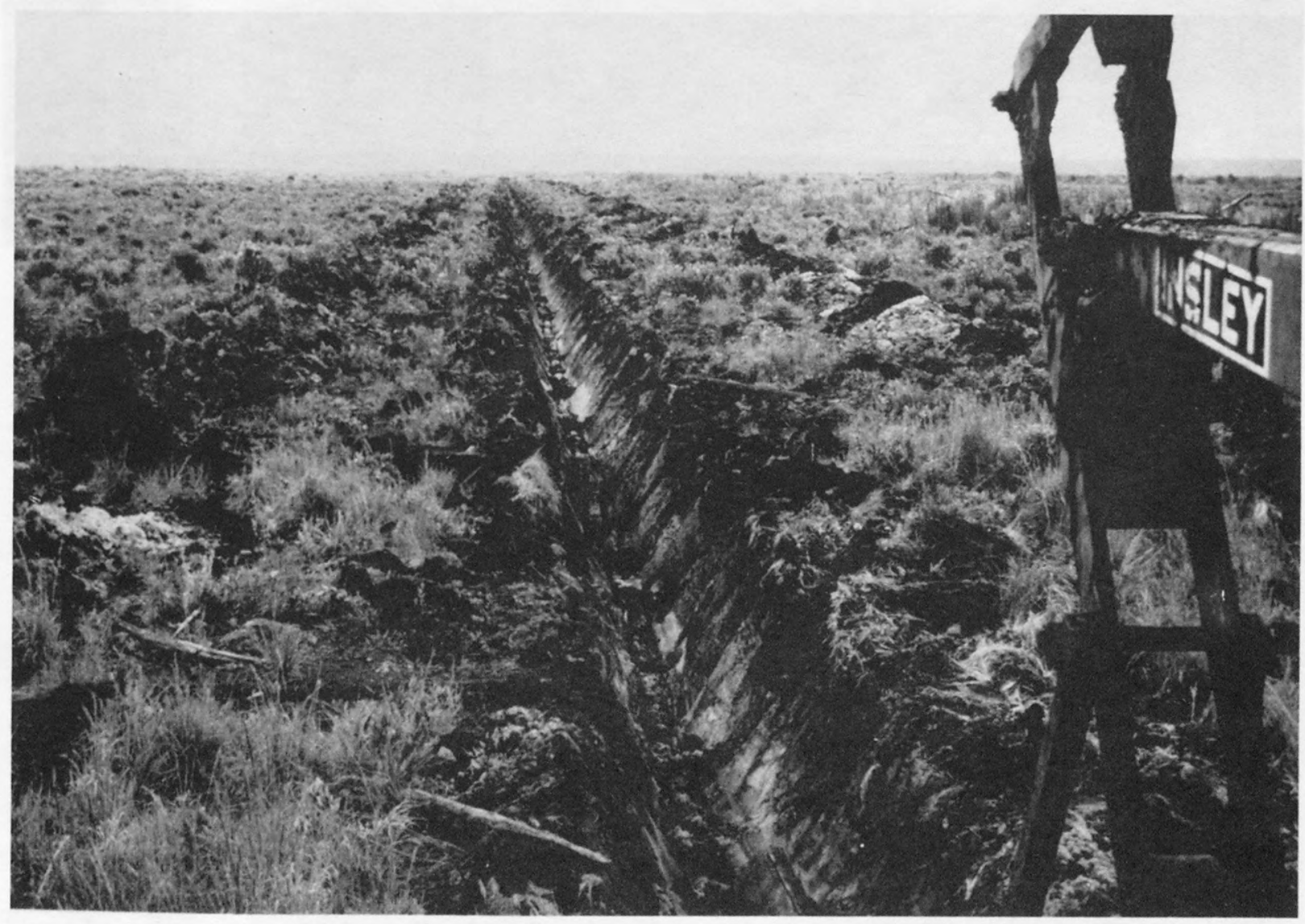

Figure 33.--Field ditch under construction, July 1974. 


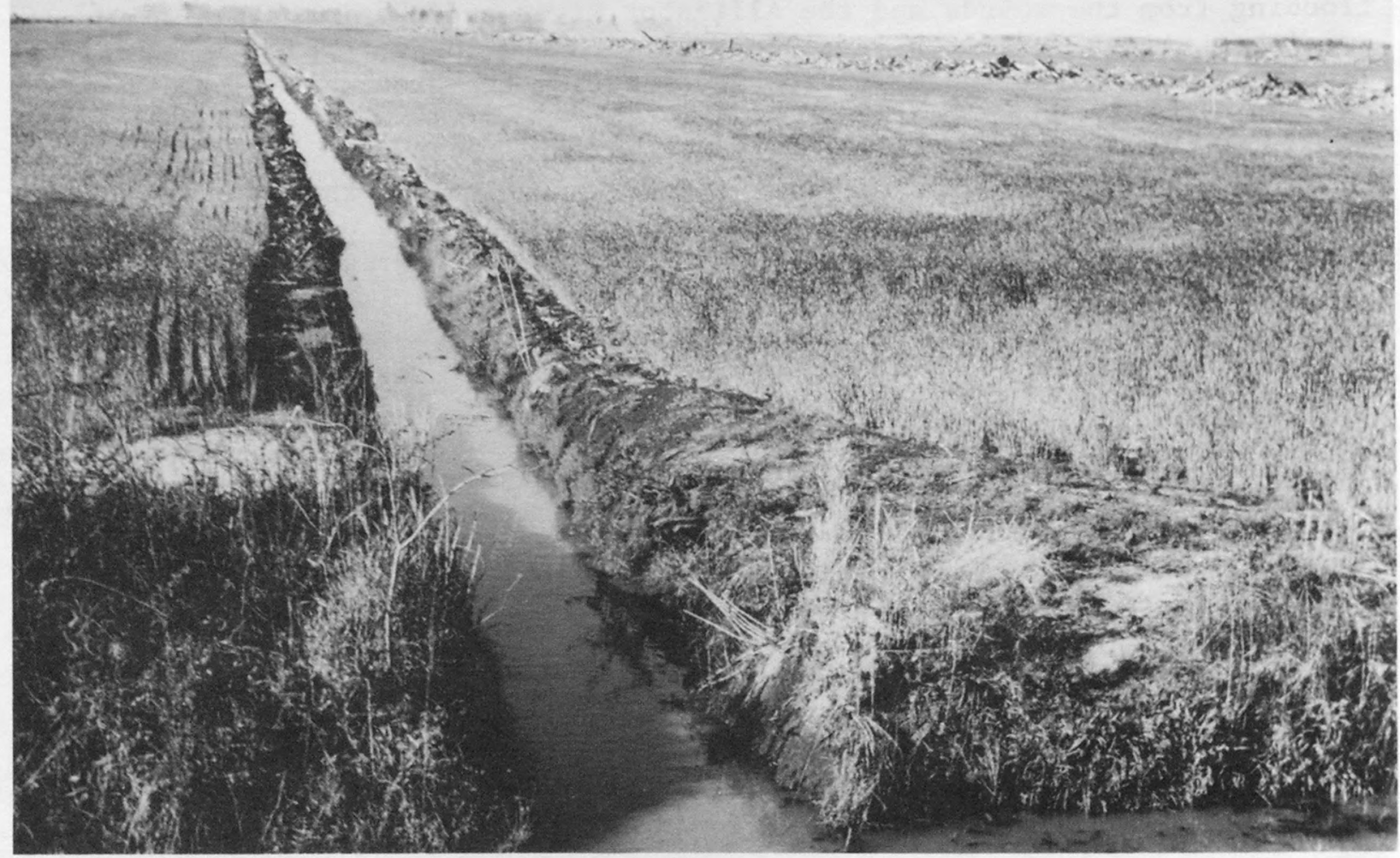

Figure 34.--Field of winter wheat, April 1974. After the wheat is harvested the field will be planted in soybeans. Note high water level in the field ditch resulting from heavy spring rains.

Phosphate Mining - The last development affecting the hydrology of the Albemarle-Pamlico region that we need to discuss is that of phosphate mining south of the Pamlico River in Beaufort County. As noted in the discussion of the Pungo River Formation, phosphate is being mined by the dry, open-pit method. To maintain a dry pit, water has been pumped since 1965 from the underlying Castle Hayne Limestone at rates ranging between 43 and $71 \mathrm{Mgal} / \mathrm{d}$ (N. C. Groundwater Section, 1974, fig. 28).

Water in the Castle Hayne is confined under pressure by clay layers in the overlying Pungo River and Yorktown Formations. Consequently, the withdrawals at the mine have caused a decline in artesian pressure throughout a large area surrounding the mine. Studies conducted by the Groundwater Section of the Department of Natural and Economic Resources indicate that the artesian pressure in the Castle Hayne Limestone has been lowered substantially for a distance of 40 miles from the center of pumping, including large areas in Washington and Hyde Counties. Artesian 
pressure has been lowered more than five feet in an area of more than 1,300 square miles and below sea level in an area of more than 800 square miles (N。C. Groundwater Section, 1974, p。45).

The height, in feet above sea level, to which water would rise in wells penetrating the Castle Hayne Limestone in June 1965, prior to the start of dewatering operations at the phosphate mine, is shown in figure 35. Because water in the limestone is confined under pressure, hydrologists refer to figure 35 as a potentiometric-surface map. The cone of depression developed by withdrawals at the phosphate mine is shown in figure 36. The hydrologic significance of the reduced artesian pressures will be discussed in the next section.

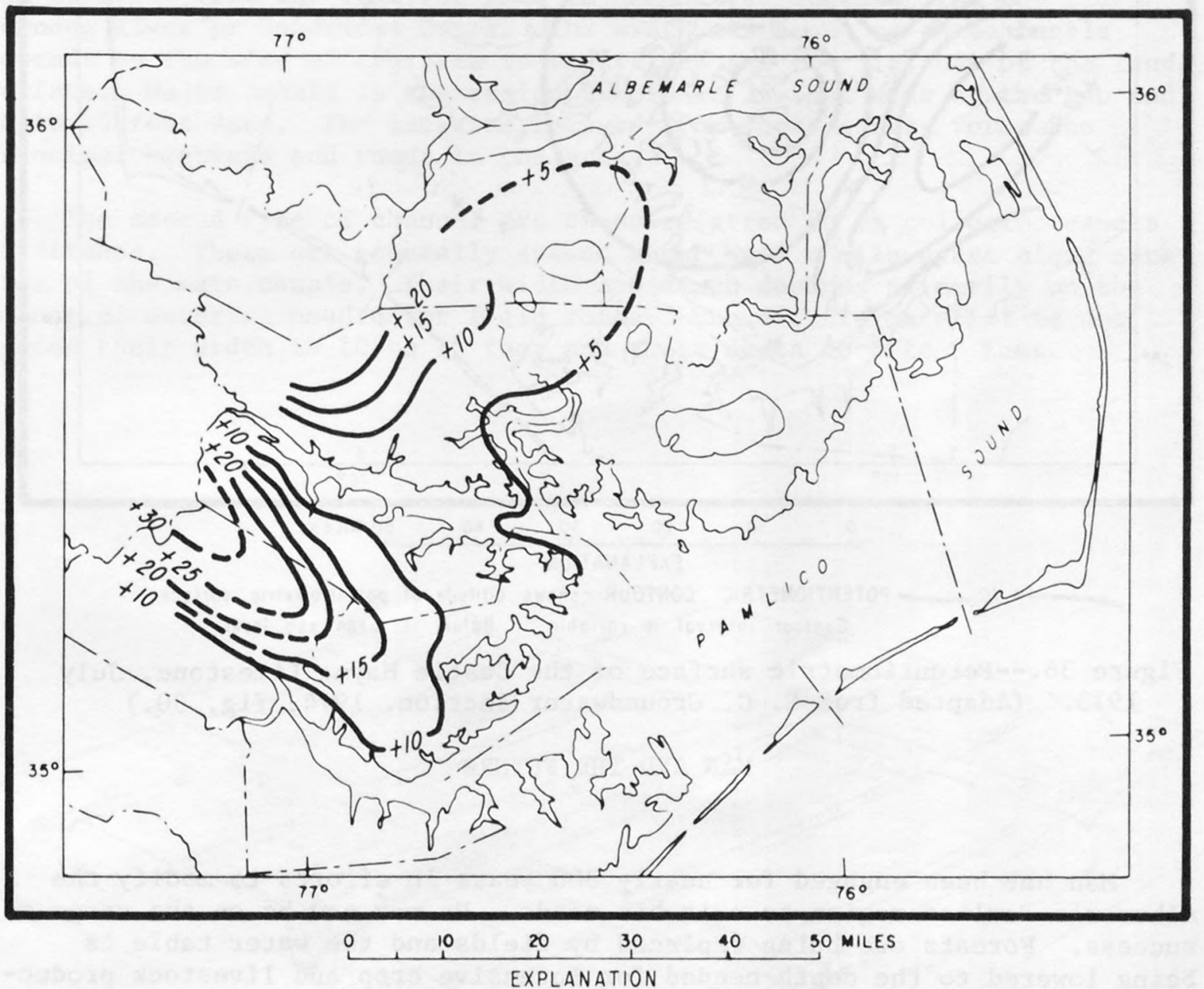

$-10-$ POTENTIOMETRIC. CONTOUR--shows altitude of potentiometric surface
Doshed where opproximately located. Contour interval 5 feet.
Dotum is mean sea level.

Figure 35.--Potentiometric surface of the Castle Hayne Limestone in June 1965, prior to the start of withdrawals at the phosphate mine in Beaufort County. (Adapted from N. C. Groundwater Section, 1974, fig. 27.) 

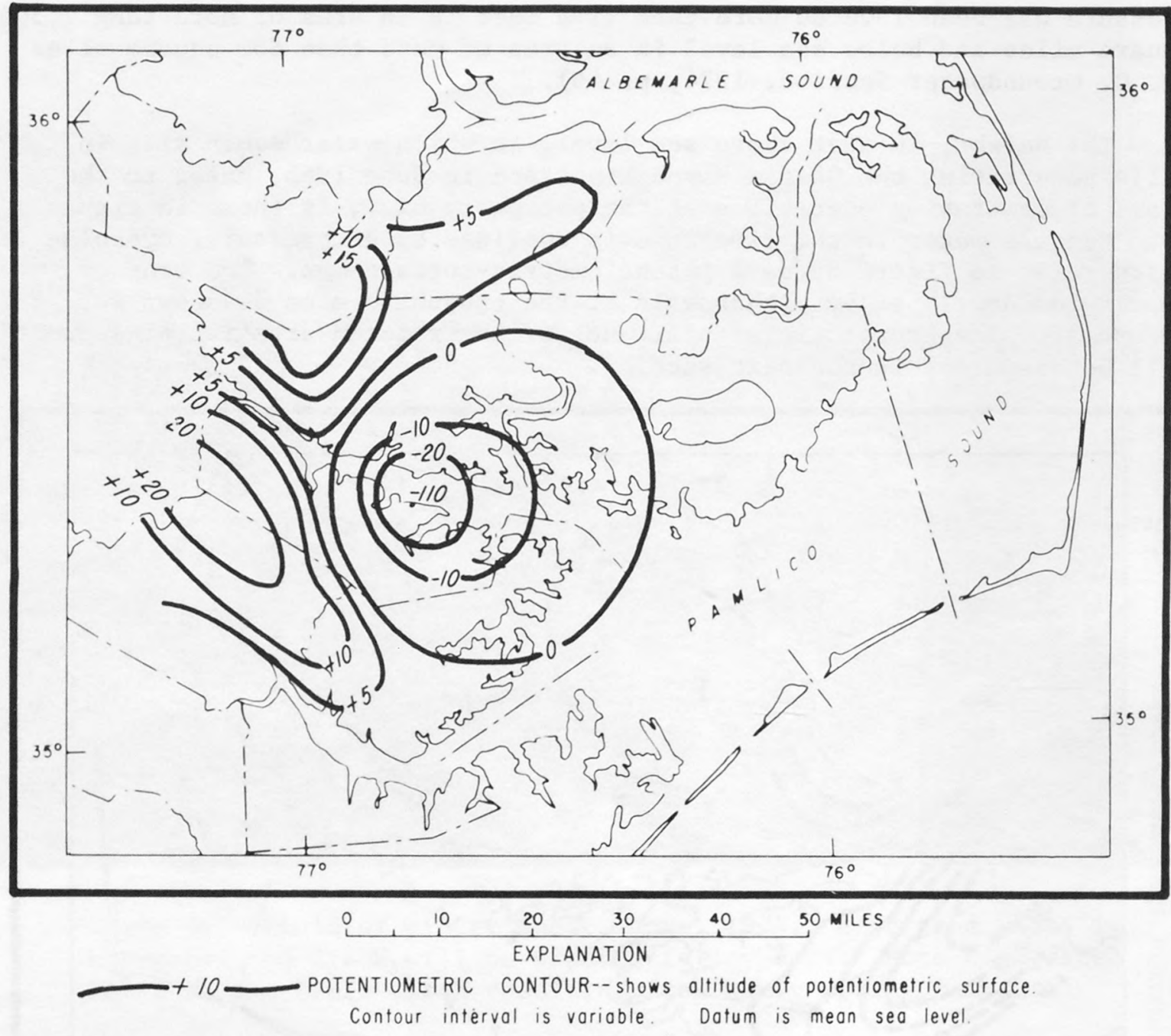

Figure 36.--Potentiometric surface of the Castle Hayne Limestone, July 1973. (Adapted from N. C. Groundwater Section, 1974, fig. 30.)

MAN AND THE FUTURE

Man has been engaged for nearly 300 years in efforts to modify the Albemarle-Pamlico region to suit his needs. He may now be on the verge of success. Forests are being replaced by fields and the water table is being lowered to the depth needed for intensive crop and livestock production. What will be the effect of these actions and how can potentially adverse effects be avoided? In the following sections we will first discuss the drainage system being constructed in the region and then discuss the impact of this system on hydrologic conditions. These sections will be followed by discussions of specific problems and the studies or actions needed to eliminate or control them. 
As noted in the preceding discussion of overland runoff, under natural conditions water on the surface of the Albemarle-Pamlico region moved slowly over the surface as a "sheet-like" flow to the short, sluggish streams around the margins of the area or to the bordering sounds and estuaries. The first step in preparing the land for cultivation is to construct channels to collect this water and convey it quickly from the area.

The ideal drainage system consists of three different types of drainage channels (fig. 37). The first are main canals which extend into the interior from the coast or from major natural streams like the scuppernong River or Kendricks Creek. The width and depth of these canals depends on the size of the area to be drained and the altitude of the 1 and surface. Major canals in the region are 15 to 25 feet wide at the top and 10 to 15 feet deep. The material removed from these canals forms the principal highways and roads in the area.

The second type of channel are those referred to as collector canals or ditches. These are generally spaced about half a mile apart along each side of the main canals. Their width and depth depends primarily on the amount of material needed for field roads. Where extra material is not needed their width is 10 to 15 feet and their depth is 6 to 8 feet.

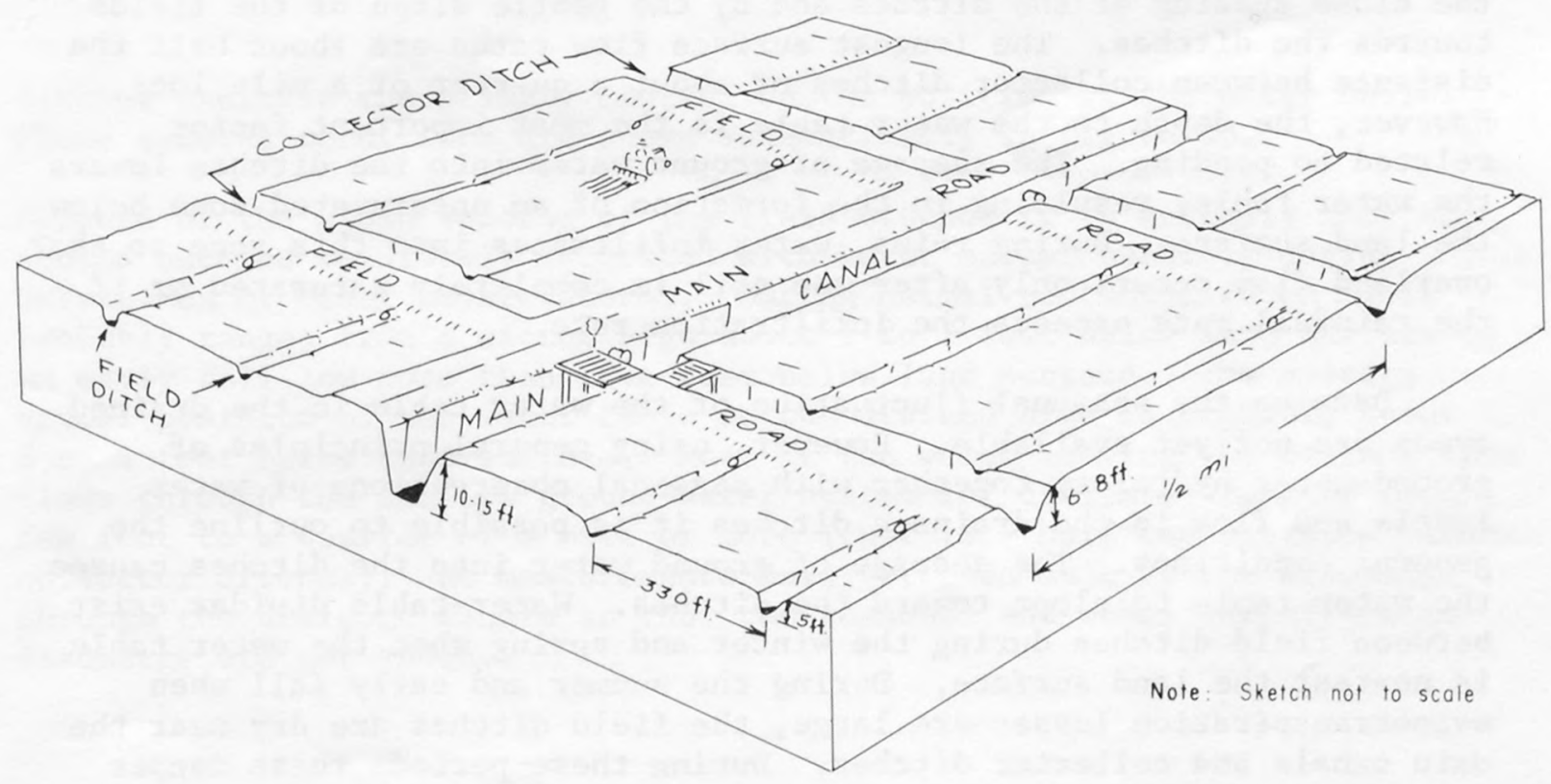

Figure 37.--Sketch of the artificial drainage system being installed. 
The third type of drainage channel are those referred to as field ditches which are spaced from 260 to 330 feet apart between the collector canals. Field ditches are dug with special power shovels which give them a constant shape and dimension. They are five feet wide at the top, five feet deep, and one foot wide at the bottom.

Although the drainage system in parts of the region approaches the ideal, it is necessary in many places to modify it to take advantage of canals dug as a part of earlier developments or to account for differences in 1 and slopes and soils. Upon completion of the drainage channels each square mile is drained through 16 to 20 miles of field ditches and three miles of collector ditches. The average for the area under cultivation is about 20 miles of channel per square mile. To compare this drainage density with the natural channels developed in other parts of the State, the length of channels of both perennial and intermittent streams were measured on several 1:24,000 scale topographic maps. The results are shown in table 4. The topographic maps listed in table 4 were selected at random to illustrate the density of natural streams in different terrains. An attempt was made to measure only natural channels.

It is apparent from table 4 that the artificial channels in the Albemarle-Pamlico region form a drainage system several times denser than the natural system developed in the higher and better drained parts of the State.

\section{Effect of Artificial Drainage on Hydrology}

The artificial drainage system being constructed in the region is designed to prevent ponding of water on the land surface during heavy rains and to remove excess water to the coast. Ponding is prevented by the close spacing of the ditches and by the gentle slope of the fields towards the ditches. The longest surface flow paths are about half the distance between collector ditches or about a quarter of a mile long. However, the depth to the water table is the most important factor related to ponding. The seepage of ground water into the ditches lowers the water table, resulting in the formation of an unsaturated zone below the 1 and surface. During rains, water infiltrates into this zone so that overland flow occurs only after the soil is completely saturated or if the rainfall rate exceeds the infiltration rate.

Data on the seasonal fluctuation of the water table in the drained areas are not yet available. However, using general principles of ground-water hydrology together with seasonal observations of water levels and flow in the drainage ditches it is possible to outline the general conditions. The seepage of ground water into the ditches causes the water table to slope toward the ditches. Water-table divides exist between field ditches during the winter and spring when the water table is nearest the land surface. During the summer and early fall when evapotranspiration losses are large, the field ditches are dry near the main canals and collector ditches. During these periods these deeper 
Table 4. Comparison of the density of natural stream channels and the artificial drainage system in the Albemarle-Pamlico region

\begin{tabular}{|c|c|c|c|c|}
\hline $\begin{array}{c}\text { Name of } \\
\text { topographic } \\
\text { map }\end{array}$ & Location & $\begin{array}{l}\text { Type of } \\
\text { terrain }\end{array}$ & $\begin{array}{l}\text { Range of } \\
\text { a1titude } \\
\text { (feet) }\end{array}$ & $\begin{array}{l}\text { Stream } \\
\text { density } \\
\left(\mathrm{Mi} / \mathrm{mi}^{2}\right)\end{array}$ \\
\hline Weaverville & Buncombe County & Mountains & $1760-3760$ & 2.83 \\
\hline Cleveland & Rowan County & Piedmont & $660-1090$ & 2.44 \\
\hline Clayton & $\begin{array}{l}\text { Wake and Johnston } \\
\text { Counties }\end{array}$ & Piedmont & $130-370$ & 2.44 \\
\hline Whitakers & $\begin{array}{l}\text { Edgecombe and } \\
\text { Nash Counties }\end{array}$ & $\begin{array}{l}\text { Piedmont-Coastal } \\
\text { Plain boundary }\end{array}$ & $60-130$ & 2.73 \\
\hline Pollocksville & $\begin{array}{l}\text { Craven and Jones } \\
\text { Counties }\end{array}$ & Coastal Plain & $5-50$ & 1.41 \\
\hline Aurora & Beaufort County & Coastal P1ain & $5-60$ & 1.46 \\
\hline $\begin{array}{l}\text { Albemarle- } \\
\text { Pamlico region } \\
\text { (artificial } \\
\text { drainage } \\
\text { system) }\end{array}$ & $\begin{array}{l}\text { Dare, Hyde, } \\
\text { Tyrrel1, and } \\
\text { Washington } \\
\text { Counties }\end{array}$ & $\begin{array}{c}\text { Outer Coastal } \\
\text { Plain }\end{array}$ & $2-20$ & 20 \\
\hline
\end{tabular}

ditches exercise the primary control on the position of the water table. These general conditions are shown schematically in figure 38 .

Because of the close spacing of the field ditches it is unlikely that the ground becomes completely saturated with water except possibly during hurricanes or other severe storms. During normal years the water table probably ranges from a winter high about 1 to 2 feet below land surface to an early fall low more than five feet below land surface. The average annual position of the water table in the drained area is probably about 3 to 4 feet below land surface. Most of the water leaving the drained area flows through the shallow ground-water system for distances ranging from a few feet to a quarter of a mile or more (that is - half the distance between collector ditches). No measurements have yet been made of the discharge through the drainage canals so that the seasonal and other variations in discharge are not known. 
WINTER AND SPRING CONDITIONS

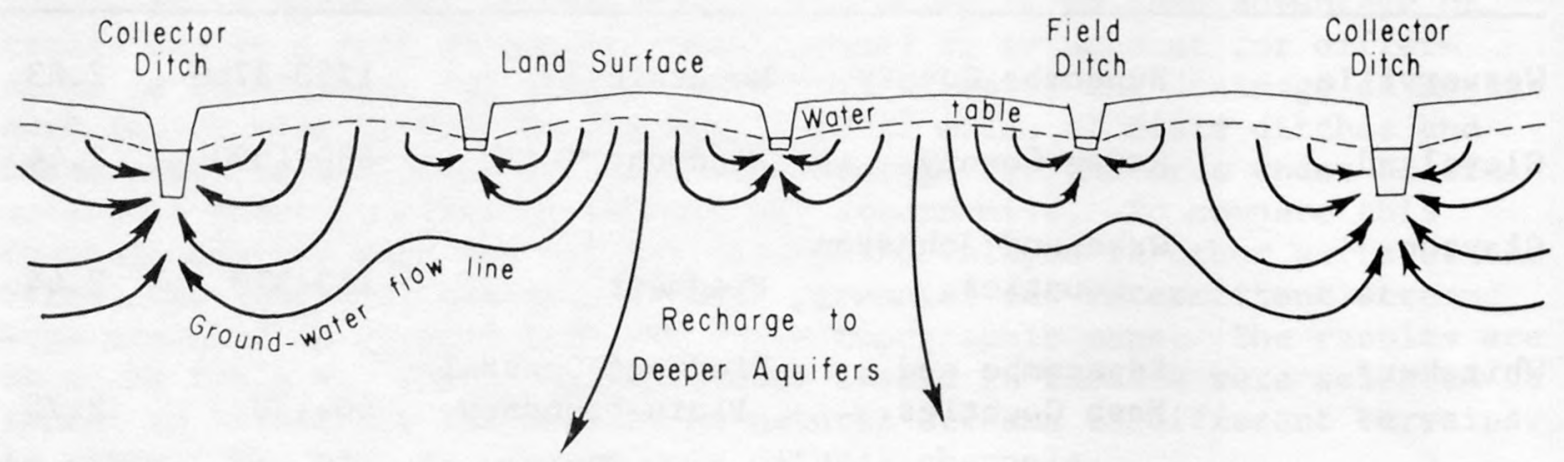

SUMMER AND FALL CONDITIONS

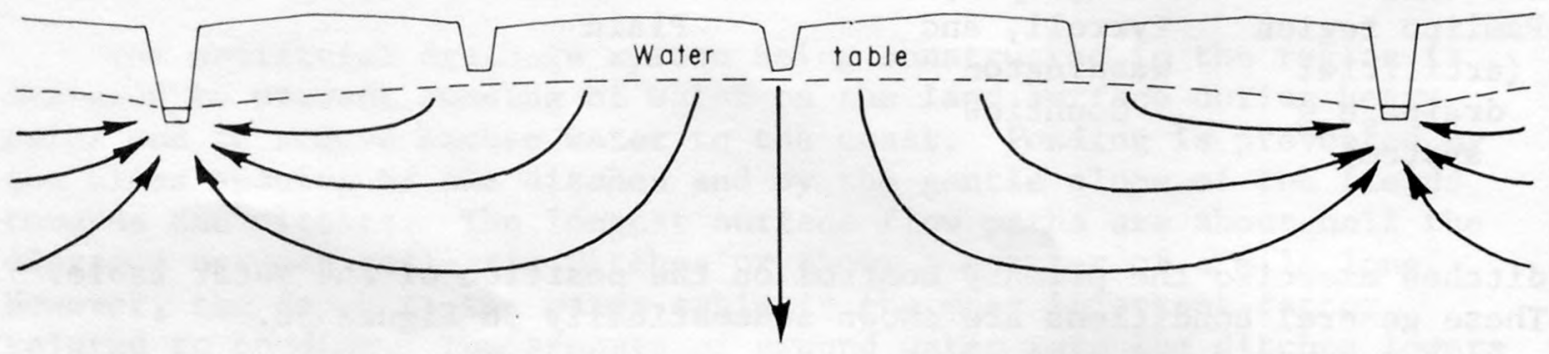

Figure 38.--Schematic representation of seasonal ground-water flow conditions in artificially drained areas. 
The effect of a considerably less dense network of drainage channels on the flow of streams has been observed in the Ahoskie Creek basin in Hertford County (fig. 2). Figure 39 is a graph showing the discharge characteristics of Ahoskie Creek at Ahoskie both before and after the natural channels were deepened and widened. Before the channelization project, from 1951 to 1962, the creek, which drains an area of 57 square miles, was dry 8 percent of the time. Since channelization the minimum discharge has been $1.8 \mathrm{ft}^{3} / \mathrm{s}$ or nearly $1.3 \mathrm{Mgal} / \mathrm{d}$. This reflects increased ground-water discharge into the deeper channels. The efficiency of the improved channels in conveying storm water from the area is also shown by the increases in maximum discharges - that is, in the discharges exceeded only about five percent of the time.

In the Albemarle-Pamlico region it is anticipated that a similar, though more pronounced, change occurs in drained areas. In other words, during and following storms the rate of runoff is considerably larger through the artificial channels than it was under natural conditions. The

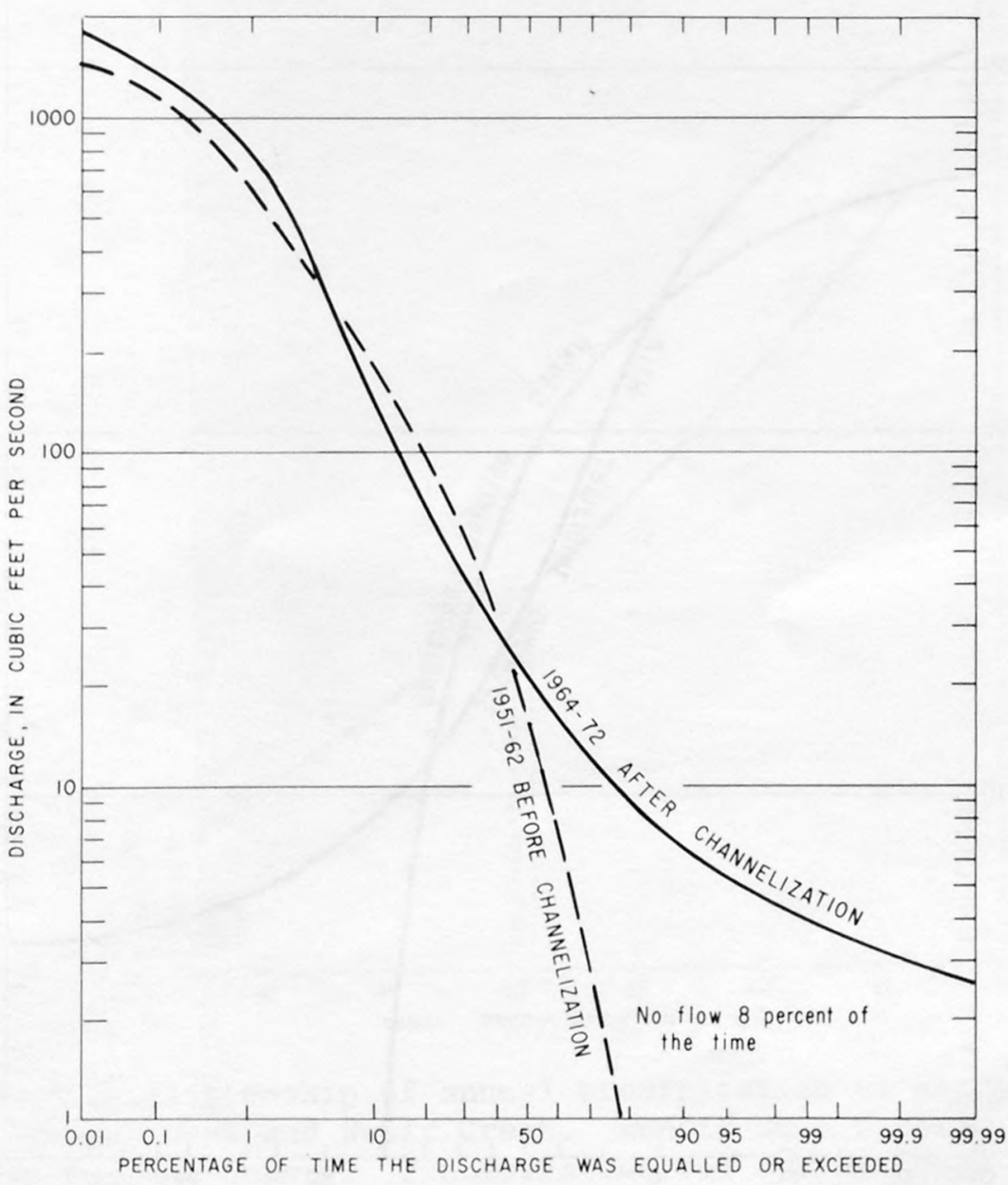

Figure 39.--Flow duration curves for Ahoskie Creek at Ahoskie both before and after channelization. 
runoff is also larger during fair weather because the channels penetrate the shallow ground-water system. Figure 40 schematically represents the anticipated change from natural conditions to conditions of artificial drainage. The principal features of the figure are that both the maximum and minimum rates of runoff are increased by the artificial drainage system.

Changes in the Water Budget - It is possible that the artificial lowering of the water table and the change in the vegetation from swamp forest to cultivated fields has an effect on the water budget of the region. The problem here is to estimate how much. Because the region after drainage resembles the more inland areas of the Coastal Plain, we may be able to utilize data from these areas in our estimates. For example, following drainage the conditions in the region may be similar to those in the Durham Creek and Swift Creek basins which are located on the peninsula south of the Pamlico River (fig. 2).

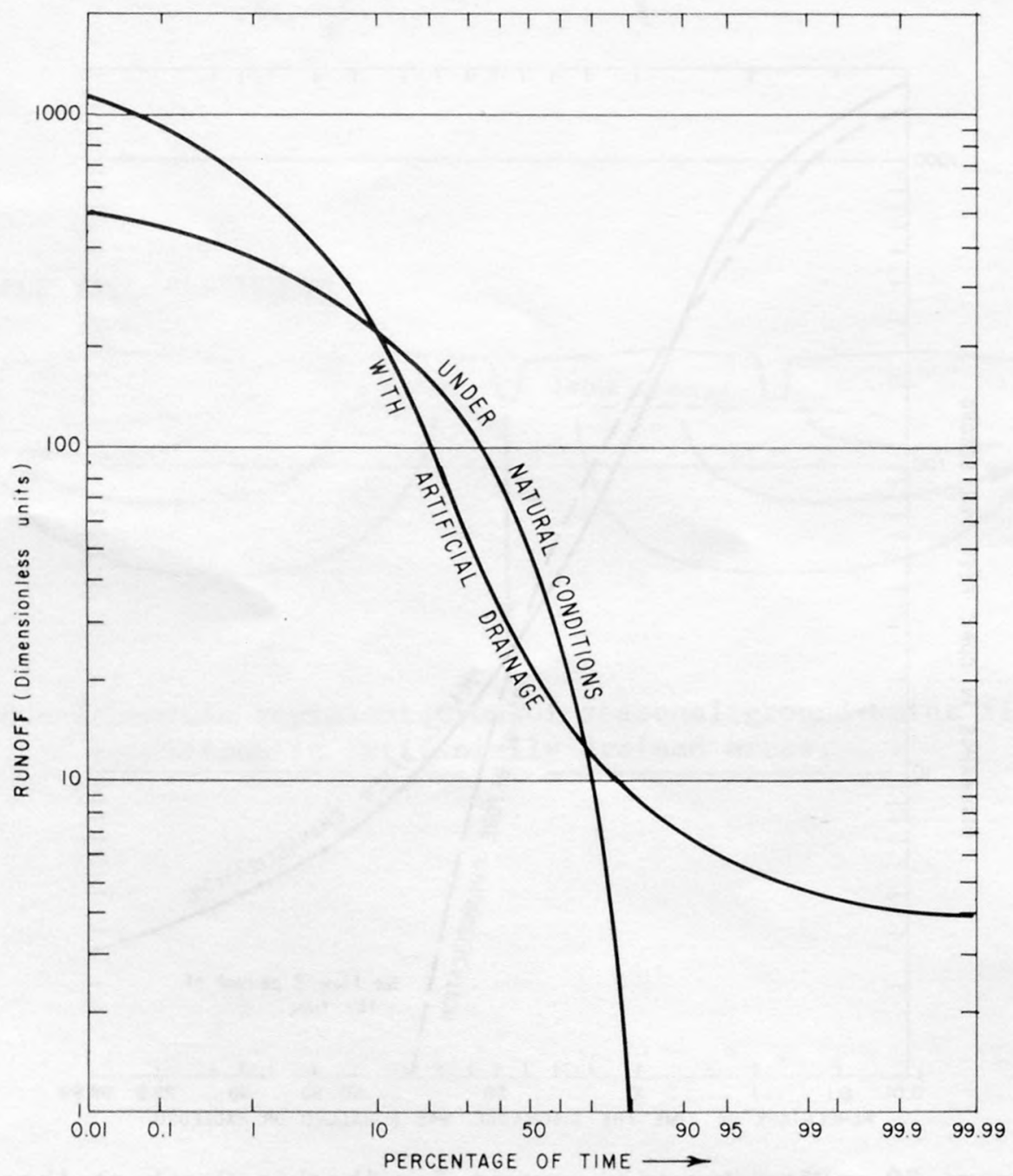

Figure 40.--Schematic flow duration curves for the Albemarle-Pamlico region before and after artificial drainage. 
The Geological Survey has measured the flow of Swift Creek near Vanceboro since 1950 and the flow of Durham Creek at Edward since 1965. Figure 41 is a graph of the annual runoff of these streams versus precipitation. Based on the relationship line drawn through the plotted points it appears that an annual precipitation of 51 inches (the average for the Albemarle-Pamlico region) yields a runoff of 15.5 inches. Surprisingly, this is only an inch more than the runoff estimated earlier for natural conditions.

The water moving out of the area through the ground-water system is decreased by the extent to which the water table is lowered by the artificial drainage system. As discussed earlier, it is estimated that the water table is lowered about three feet by the drainage system; from an average position about one foot below land surface to an average position about four feet below land surface. The effect of this lowering on ground-water gradients depends on the initial height of the water

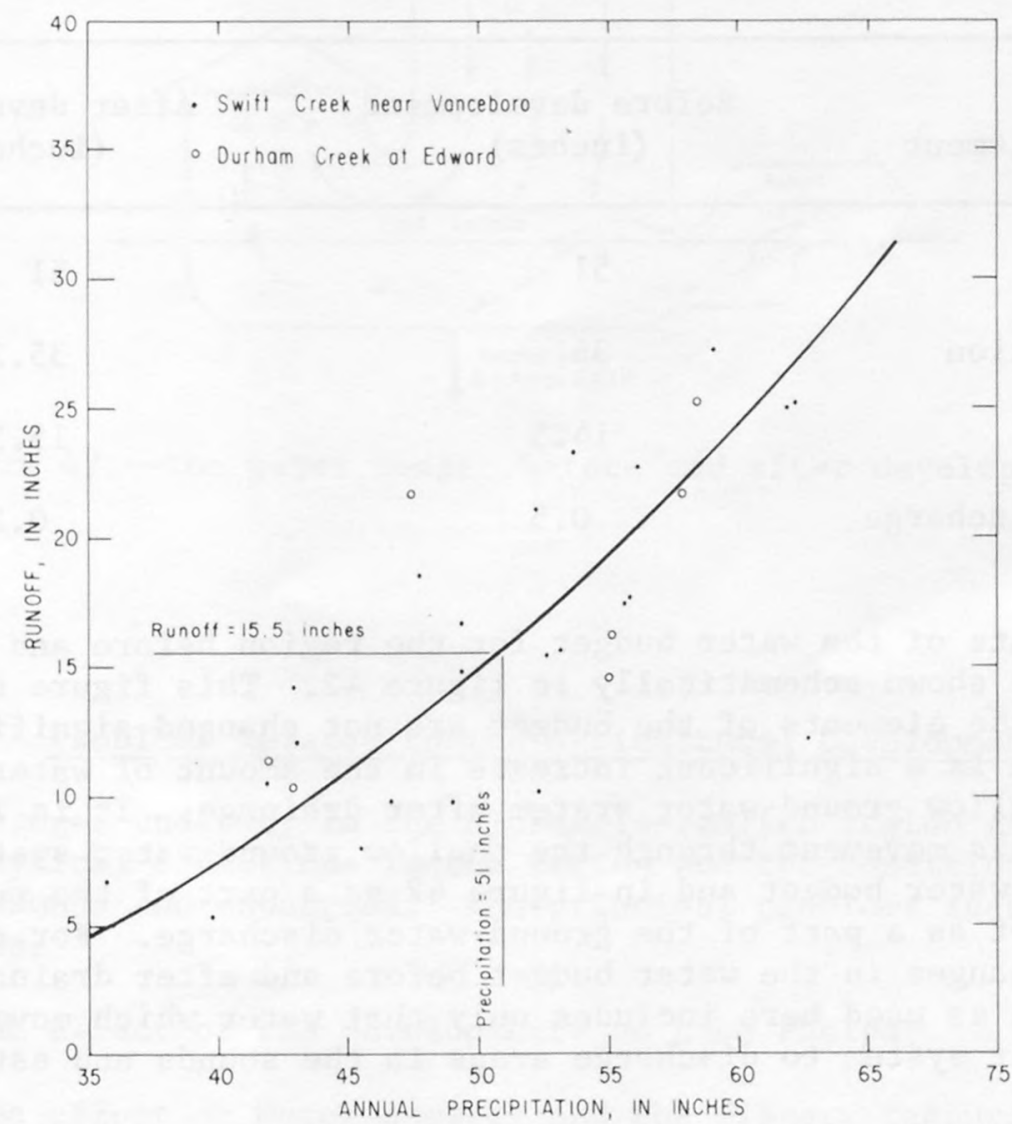

Figure 41.--Relationship of annual precipitation to annual runoff for Durham Creek and Swift Creek。 Runoff from records of the U. S. Geological Survey. Precipitation for Durham Creek is the average of National Weather Service records for Belhaven and New Bern Airport. Precipitation for Swift Creek is average of NWS records for Greenville, New Bern Airport, and Washington. 
table. Where the initial height of the water table was 14 feet above sea level a lowering of three feet amounts to about 20 percent. Where the initial height was three feet above sea level a lowering of three feet is 100 percent. For the area as a whole, ground-water gradients will probably be reduced about 50 percent upon completion of the drainage system or to half their initial value. Consequently, the water moving out of the region through the ground-water system will be reduced by half or from about 0.5 inch to about 0.25 inch.

The water budgets before and after development are compared in the following table. The runoff before development consists of sheet flow over the surface. After development it consists of outflow through the artificial channels. The values for the different elements indicate, at best, only the relative order of magnitude. With the possible exception of ground-water discharge, none are probably within an inch of the actual value. But, in any case, they indicate that the water budget is essentially the same under both the natural and drained conditions.

Water-budget element

Before development (inches)
After development (inches)
Precipitation

Evapotranspiration

Runoff

Ground-water discharge
51

36

14.5

0.5
51

35.25

15.5

0.25

The elements of the water budget for the region before and after development are shown schematically in figure 42. This figure suggests that although the elements of the budget are not changed significantly by drainage, there is a significant increase in the amount of water moving through the shallow ground-water system after drainage. It is important to note that this movement through the shallow ground-water system is treated in the water budget and in figure 42 as a part of the runoff from the area and not as a part of the ground-water discharge. For convenience in comparing changes in the water budget before and after drainage, groundwater discharge as used here includes only that water which moved through the ground-water system to discharge areas in the sounds and estuaries. 

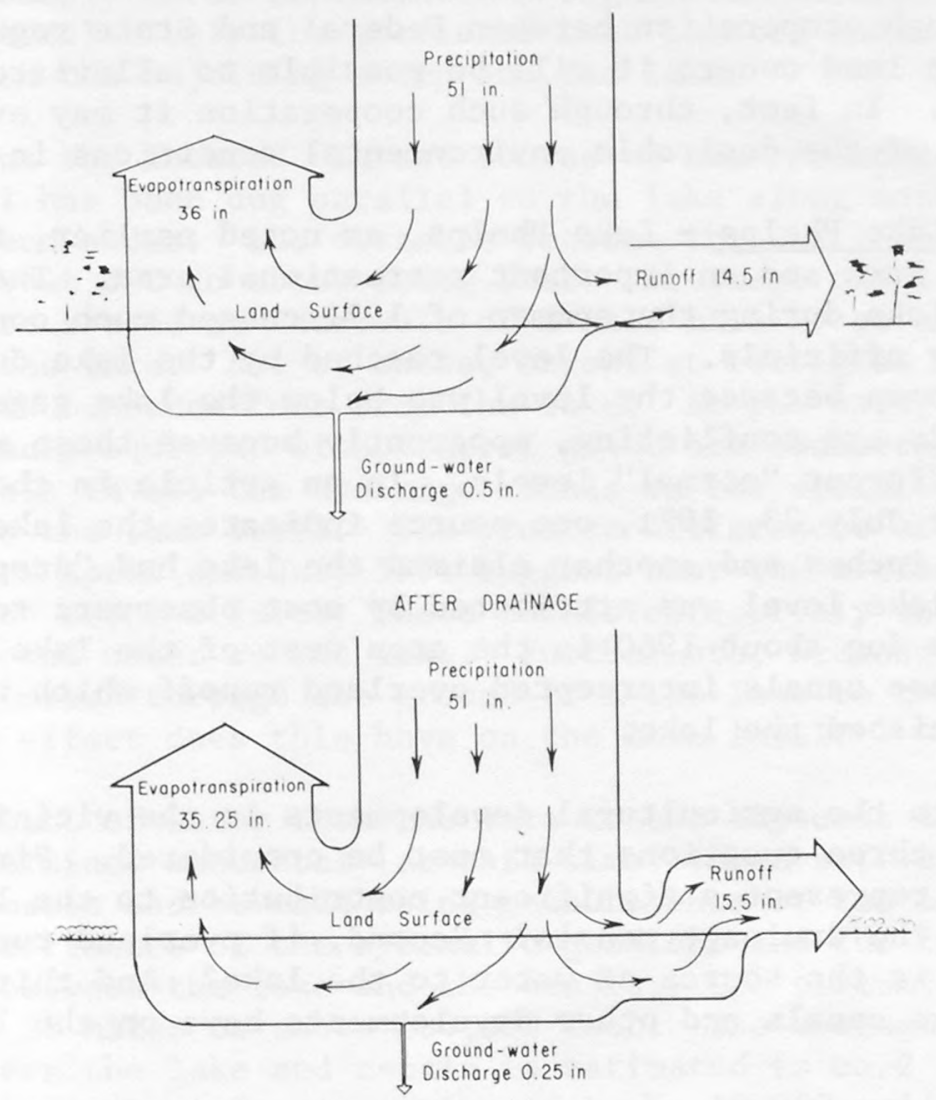

Figure 42.--The water budget before and after development.

\section{Problems Related to the Agricultural Developments}

The changes underway in the Albemarle-Pamlico region are affecting both the physical conditions in the region and the conditions in the adjoining sounds and estuaries. The principal problems identified at this time include:

1. the effect of the developments on Lake Phelps,

2. the effect on water quality and the fishery resources of the sounds and estuaries,

3. the effect on conditions in the area, particularly on subsidence and oxidation of the peat, and

4. the effect on ground-water conditions and the position of the fresh water-salt water interface. 
There is no practical way to eliminate all of these problems but, hopefully, through cooperation between Federal and State regulatory agencies and the land owners it will be possible to alleviate many of the adverse effects. In fact, through such cooperation it may even be possible to enhance some of the desirable environmental conditions in the region.

Effect on Lake Phelps - Lake Phelps, as noted earlier, is a part of Pettigrew State Park and an important recreational area. The low level reached by the lake during the summer of 1971 caused much concern among State and county officials. The level reached by the lake during this period is not known because the level was below the lake gage (fig. 14). Published reports are conflicting, apparently because those making the reports used different "normal" levels. In an article in the Raleigh News and Observer for July 23, 1971, one source indicates the lake level was "down" 16 to 18 inches and another claimed the lake had "dropped" 3 to 4 feet. The low lake level was attributed by most observers to drainage canals that were dug about 1960 in the area west of the lake. It was visualized that these canals intercepted overland runoff which would otherwise have replenished the lake。

In regard to the agricultural developments in the vicinity of the lake, there are three questions that must be considered. First, did overland runoff represent a significant contribution to the lake prior to construction of the drainage canals? Second, if overland runoff was not important, what is the source of water to the lake? And third, what effect will the drainage canals and other developments have on the lake in the future?

Relative to the first question, it is doubtful that any significant amount of overland runoff entered Lake Phelps prior to construction of the drainage canals. Such runoff could only originate in the higher area to the south and west and, because that area is underlain by thick organic soils, the runoff from it would be highly colored. The lake water, on the other hand, is reported to have always been exceptionally free of color. (See table 3 for a recent analysis。) Furthermore, the low ridge around the south and west sides of the lake would prevent overland runoff from reaching the lake until water reached a depth of a foot or two in the swamp.

If overland runoff did not originally represent a significant contribution to the lake, what is its source of replenishment? The only sources left are precipitation and ground-water inflow. Of these, precipitation is clearly the dominant one. The mean annual precipitation on the lake is about the same as the average for the region - that is, about 51 inches. Evaporation from the lake is estimated to be about 0.7 of the annual pan evaporation of 51.24 inches measured in the Hofmann Forest or about 36 inches per year. Thus, precipitation on the lake during an average year exceeds evaporation by about 15 inches. The precipitation record at New Holland (fig. 24) suggests that over a long period of time annual precipitation probably ranges from about five inches less to about 30 inches more than evaporation. The chemical quality of the water in the lake indicates that it is precipitation that has been concentrated by evaporation (table 3). Ground-water inflow, the second source mentioned 
above, has probably never represented a significant source of replenishment because of the relatively low gradients that existed under natural conditions between the adjoining swamp and the lake.

What about the future? In the course of the recent developments a drainage canal has been dug parallel to the lake along most of the west and southwestern sides. The distance between the canal and the lake ranges from about 300 to about 1,000 feet. Drainage canals perpendicular to the lake are spaced at intervals of a half mile or so around the remainder of the lake. All of these, except at Pettigrew State Park, terminate a few hundered feet from the lake. At the park, as noted earlier, four canals equipped with control gates are connected to the lake. The water levels in all the drainage canals in the vicinity of the lake are lower than the lake level. The precise differences are not known but observations in April and July 1974 suggest that the differences may range from about 2 to about 5 feet. These canals effectively short-circuit seepage of ground water to the lake. Furthermore, because of their lower levels, water moves through the ground from the lake to the drainage canals. What effect does this have on the lake level?

The movement of water from the lake to the adjacent drainage canals cannot be determined accurately at this time. However, we believe fairly reliable estimates can be made using measurements of the circumference of the lake and estimates of the hydraulic gradient and the transmissivity of the material between the lake and the canals. The circumference of the lake is about 20 miles or about 106,000 feet. The average hydraulic gradient between the lake and canals is estimated to be 2 feet in 1,000 feet and the transmissivity is estimated to be $10,000 \mathrm{gal} / \mathrm{d} / \mathrm{ft}$ $\left(1,340 \mathrm{ft}^{2} / \mathrm{d}\right)$. Using Darcy's Law of ground-water flow these values yield an outflow from the lake through the ground to the drainage canals of $2 \mathrm{Mgal} / \mathrm{d}$ or $730 \mathrm{Mgal} / \mathrm{yr}$. At its "normal" leve1 of 10 feet above sea leve1 an inch of depth of the lake contains about $435 \mathrm{Mgal}$. Therefore, the annual movement of water from the lake through the ground-water system to the drainage canals represents only about two inches of lake depth.

During years when precipitation exceeds evaporation it is necessary to drain water from the lake through the control canals at Pettigrew State Park. Farmers between the lake and the Scuppernong River have complained that this drainage causes the deposition of sediment in the canals. Very fine-grained mud appears to accumulate along the northeastern side of the lake, possibly as a result of the prevailing southwesterly winds. This mud apparent1y stays part1y suspended even in the relatively quiet water along the shore of the lake and should move readily down the drainage canals to the Scuppernong River. A study of this problem is now being conducted by the U. S. Soil Conservation Service and a report on it is scheduled for completion early in 1975 (Douglas Hattersley, oral commun., December 3, 1974).

One other topic that should be mentioned in connection with Lake Phelps concerns the construction of homes around the margin of the lake. Clusters of homes are now located at several places along the west side 
of the lake and, ultimately, when the area is reached by a paved road the construction of homes will probably accelerate. Most of the existing homes obtain water from shallow driven wells and all dispose of wastes through septic tanks and drain fields. Unless precautions are taken, both the shallow aquifer and the lake may become polluted from this source.

Problems associated with Lake Phelps have been discussed in the preceding paragraphs. With respect to the future, management actions might include consideration of the following:

1. Monitoring the lake level - Effective management of the lake is not possible without an accurate and unbroken daily record of the lake stage. A staff gage established in water deep enough to cover the maximum probable range in stage could provide this data. (A new staff gage was installed in the deeper water at the end of the park dock by the U. S. Geological Survey on January 10, 1975.)

2. Confirming seepage from the lake - The estimate of seepage from the lake to drainage canals suggests that this loss is not excessive. However, in view of the importance of the lake, two or three lines of shallow observation we1ls constructed between the lake and the canals would permit a better estimate of the seepage to be made.

3. Preparation of release guidelines - The leve1 of the lake must be artificially lowered from time to time to avoid inundation of the farmland along the northwest side of the lake. Guidelines similar to the operating rules for reservoirs, which would clearly spe11 out when water should be released and at what rate, would be of great value to the local park officials. Because precipitation is the primary source of replenishment, careful attention must be given in preparing the guidelines to the seasonal differences in precipitation and evaporation. The guidelines could also deal specifically with releases prior to and during hurricanes and other major storms.

4. Control of releases - The gates presently used to release water are located near the bottom of the control structures 5 to 6 feet below the "normal" lake level. The gates are difficult to operate, difficult to maintain, and leak sizable quantities of water. The present bottom control gates could be sealed and replaced with flow-rated surface-control gates. Such gates can be more easily maintained and can be constructed to prevent excessive lowering of the lake leve1. Drawing water off the surface of the lake would avoid the sediment problems reportedly caused by the present bottom gates. Once installed, the gates would need to be rated and an accurate record of releases maintained. 
5. Expanded use of the lake - The relatively high altitude of Lake Phelps and its position near the center of a large agricultural area raises the possibility that it might be a particularly valuable element in a water-management plan for the region. Through careful regulation of the lake level it might serve, for example, as a supplemental source of water during droughts or peat fires. Another aspect that could be considered is that of using excess water from the lake to recharge the Castle Hayne Limestone. Because of the clarity and chemical quality of the lake water it would appear to be an ideal source of recharge and the use of the water for this purpose might not only alleviate the need for canal drainage but also improve ground-water conditions.

6. Control of waste disposal - The development of residential areas around the margin of the lake poses a possible pollution problem to the shallow aquifer, the lake, and the drainage canals. Because the aquifer is used in the residential areas as a source of water supply and the lake is used for swimming and other water-contact recreation, it is desirable that pollution of these be avoided to the extent possible.

Effect on Water Quality of the Sounds and Estuaries - The sounds and estuaries surrounding the Albemarle-Pamlico peninsula contain varying mixtures of fresh water and sea water. Fresh water reaches the estuaries as precipitation and through streams draining the tributary land area. Sea water enters through inlets in the Outer Banks. The salinity of water in the sounds and estuaries is primarily controlled by the fresh-water inflow. Because of the large volume of the estuaries and the relatively small size of the inlets, oceanic tides do not cause significant variations in salinity, except near the inlets.

The tidal streams and marshes of the peninsula are important spawning and nursery areas for fish and shrimp. In addition, the shallow waters along the shores of Hyde and Dare Counties contain important oyster beds. (See fig. 43.) Because all of these uses are sensitive to changes in salinity and other aspects of water quality, any developments which affect these are of concern to the seafood industry. It is not possible at this time to determine the extent to which the agricultural developments in the region will affect the water quality of the areas important to seafood production. However, because of the efficiency of the artificial drainage system, runoff will occur much faster during wet periods than was the case under natural conditions. It is expected that this runoff will not only have a significant effect on salinity of the estuarine waters adjacent to the peninsula but will also contribute substantial amounts of bacteria, nutrients, pesticides, and sediment. In fact, the effect of runoff from the region on the quality of the nearby estuarine waters may be the most important problem posed by the agricultural developments. 


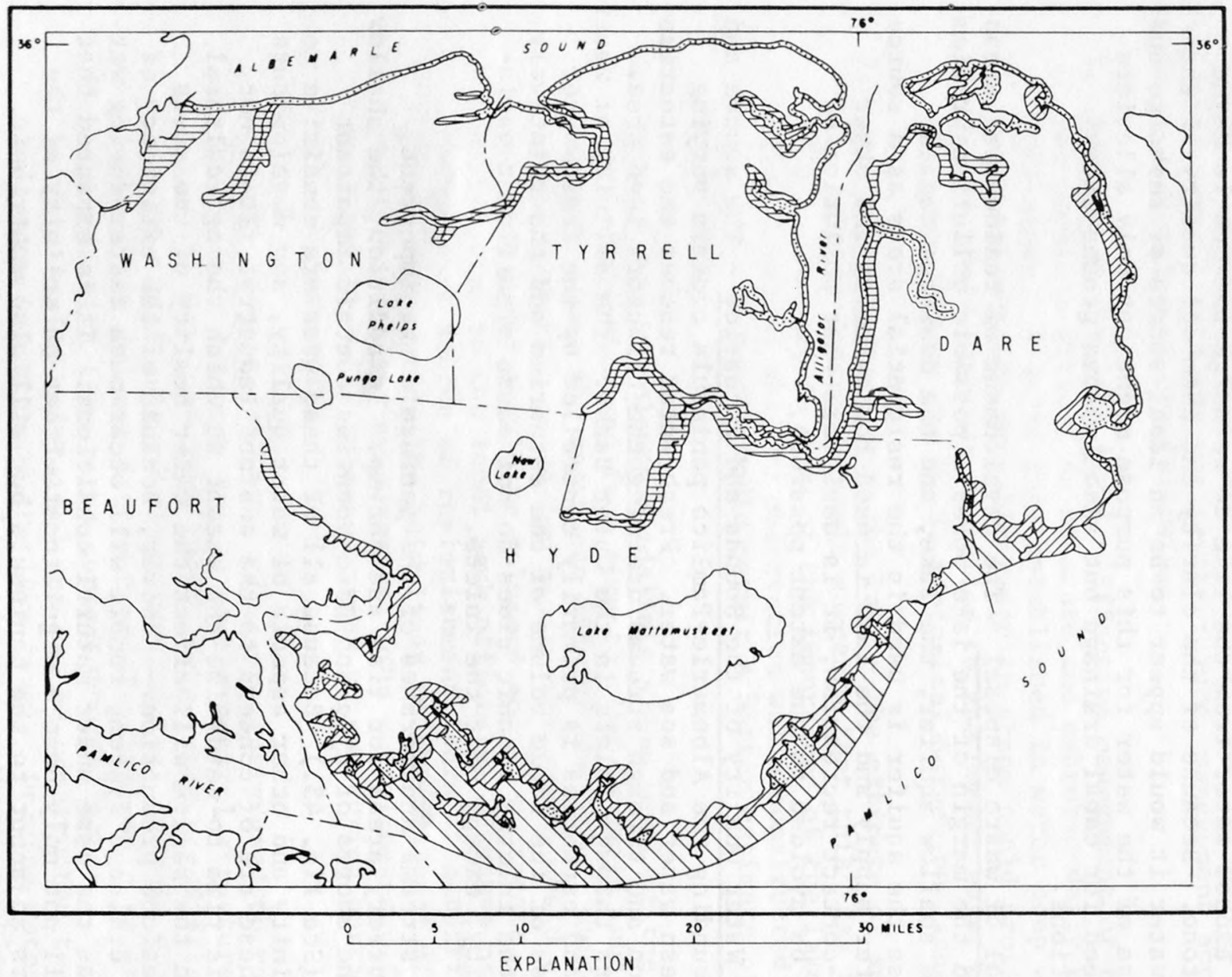

DIIT Submerged grass beds; Regularly and irregularly flooded marshes.

State oyster management areas and

Shrimp, crab, and fish nursery areas

natural populations of oysters; clams; scallops.

Primary anadramous fish spawning areas.

Figure 43.--Areas determined by the State Department of Natural and Economic Resources to be important for seafood production. 
In discussing this problem it is logical to start with the effect of the runoff on salinity. Variations in the salinity of the State's major estuaries has been determined by Williams and others (1967). Figures 44 and 45 show the average salinity of the surface of Albemarle Sound and the Pamlico River for April and December. These months were chosen because they generally represent, respectively, the months of minimum and maximum sea-water intrusion. The differences in salinity shown on these figures reflect seasonal differences in fresh-water inflow.

Fresh water enters Albemarle Sound from an area of about 17,600 square miles including, because of precipitation, the area of the sound itself. Of this area, about 1,000 square miles are located in the Albemarle-Pamlico region. Fresh water enters the Pamlico River from an area of 4,300 square miles, again, including the river itself. Of this area, about 350 square miles are located in the Albemarle-Pamlico region. As a first approximation, we can assume that the fresh-water contribution to the estuaries from the region is proportional to the drainage areas. For Albemarle Sound it is about 6 percent and for the Pamlico River about

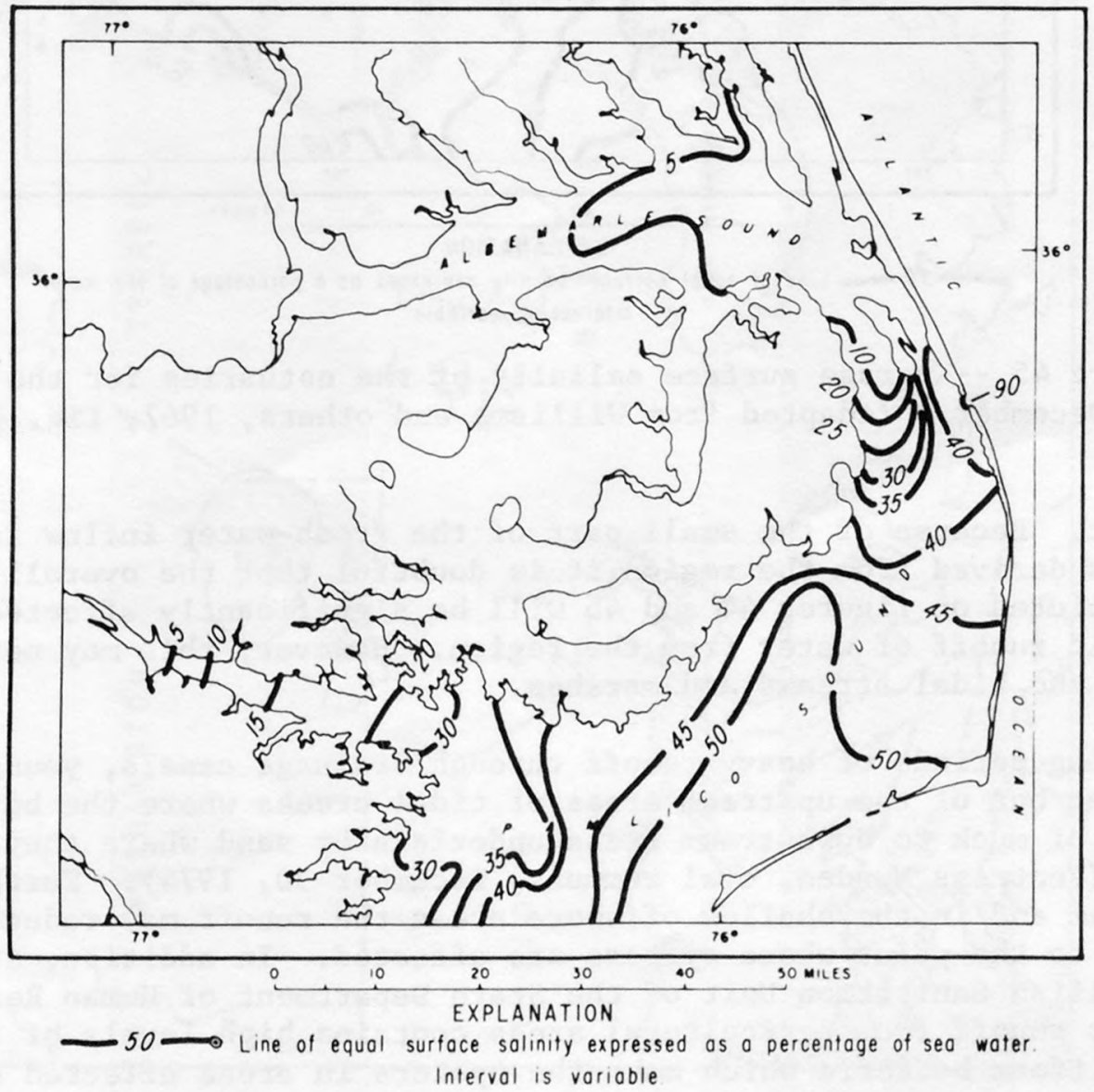

Figure 44.--Average surface salinity of the estuaries for the month of Apri1. (Adapted from Williams and others, 1967, fig. 16.) 


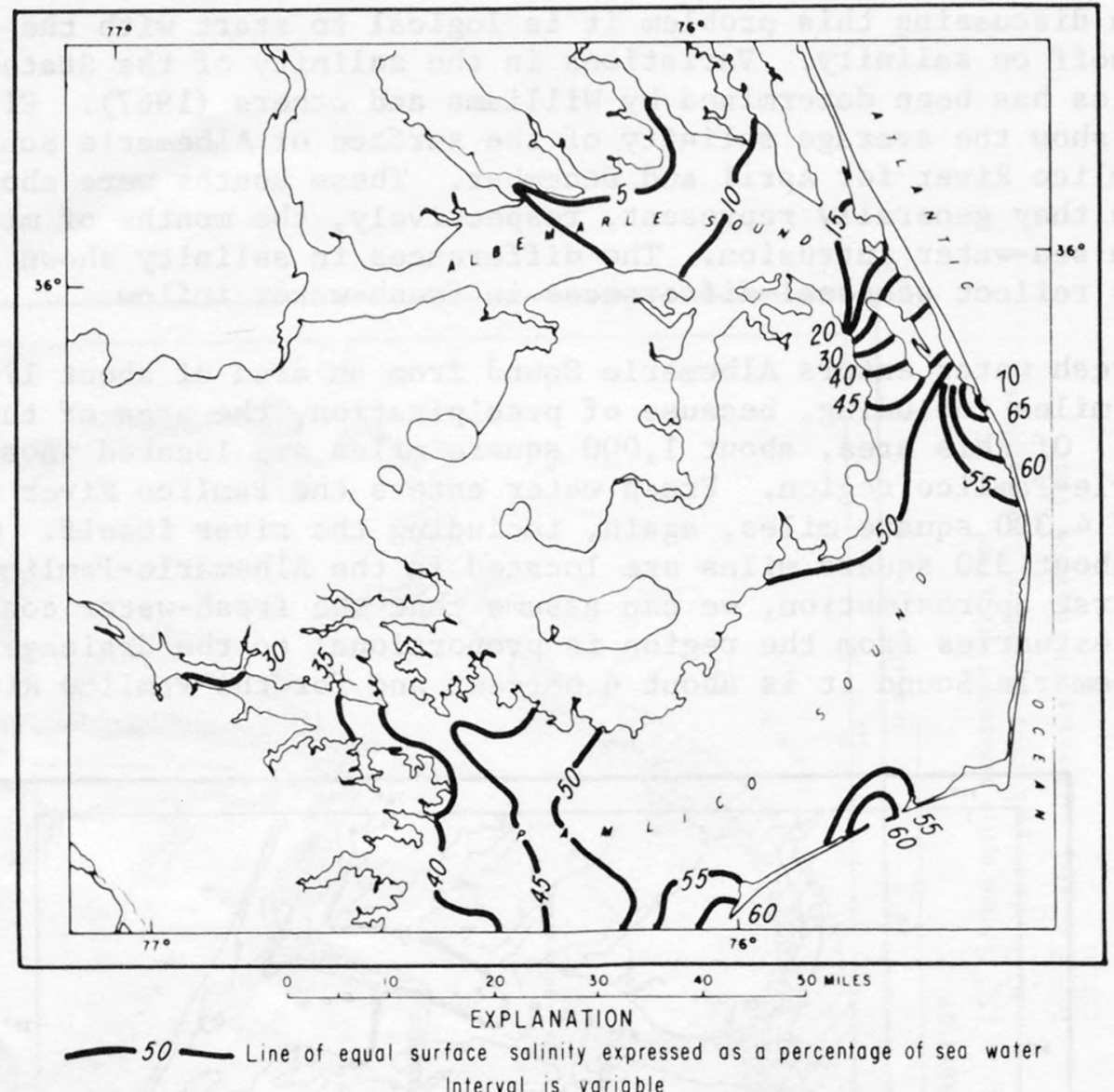

Figure 45.--Average surface salinity of the estuaries for the month of December. (Adapted from Williams and others, 1967, fig. 48.)

8 percent. Because of the small part of the fresh-water inflow to these estuaries derived from the region it is doubtful that the overall conditions depicted on figures 44 and 45 will be significantly affected by the more rapid runoff of water from the region. However, this may not be the case for the tidal streams and marshes.

During periods of heavy runoff through drainage canals, young shrimp are driven out of the upstream areas of tidal creeks where the bottoms are composed of muck to downstream areas underlain by sand where they cannot survive (Fentriss Munden, oral commun., December 30, 1974). Farther downstream and in the shallow offshore areas the runoff may reduce the salinity to the point where oysters are affected. In addition, studies by the Shellfish Sanitation Unit of the State Department of Human Resources show that runoff from agricultural areas contains high levels of total and fecal coliform bacteria which make the oysters in areas affected by such runoff unsuitable for human consumption (Robert Benton, oral commun., December 30, 1974). Figure 46 shows areas around the Albemarle-Pamlico peninsula in which harvesting of oysters and clams is prohibited. 


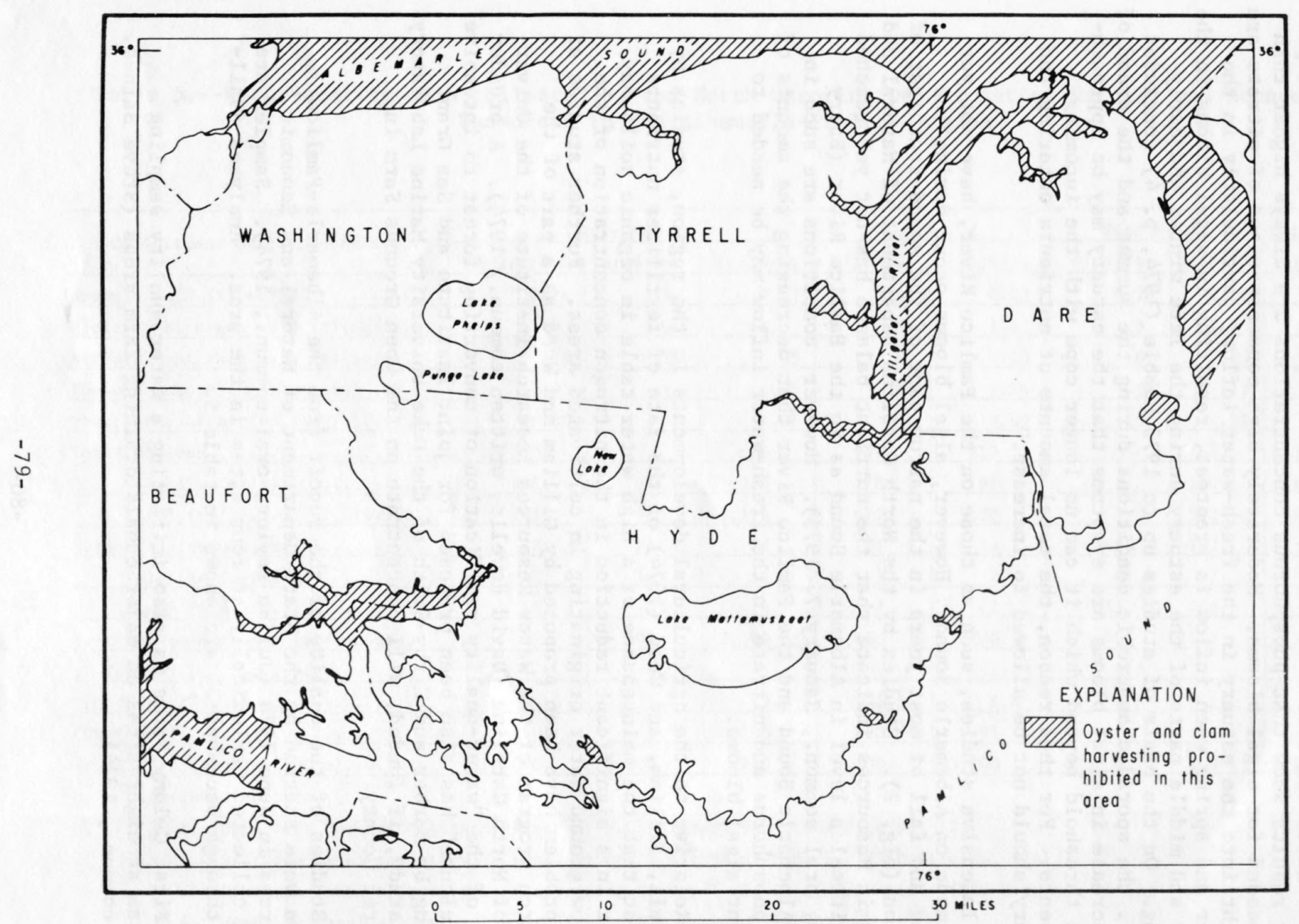

Figure 46.--Estuarine areas in which oyster and clam harvesting is prohibited. (Based on maps supplied by the Shellfish Sanitation Unit of the State Department of Human Resources.) 
Relative to nutrients - that is, compounds of nitrogen and phosphorous - Hobbie (1974) and his coworkers have conducted intensive studies in the Pamlico River since 1965 to determine the eutrophic state of the estuary. Their results show that phosphorous concentrations are always higher than are needed for algal blooms. Moderately high concentrations of nitrate are brought into the estuary in the fresh-water inflow, particularly in the winter and spring when inflow is greatest, resulting in algal blooms in the upper and middle parts of the estuary during the late winter and early spring. On the basis of studies up to 1973 Hobbie (1974, p. 4) concludes ". . the sporadic anaerobic conditions during the summer and the trend of an increase in algal blooms are symptoms that the estuary may be approaching a threshold beyond which it can no longer cope with the incoming nutrients. For this reason, the total amounts of nutrients entering the estuary should not be allowed to increase."

Intensive studies, such as those on the Pamlico River, have not yet been made on Albemarle Sound. However, algal blooms occur during the spring and fall of most years in the narrow part of the sound southeast of Edenton (fig. 2). Studies by the North Carolina Department of Natural and Economic Resources indicate that the nutrient balance has not yet reached as critical a level in Albemarle Sound as in the Pamlico River (Barry Adams, oral commun., January 7, 1975). However, conditions are such in both Albemarle Sound and the Pamlico River that decreasing the amounts of both phosphorus and nitrate in the fresh-water inflow may be needed to prevent algal blooms.

Relative to the agricultural developments in the region, studies by Gambre11, Gilliam, and Weed (1974) of the fate of fertilizer nutrients suggest that the maintenance of a high water table in organic soils may result in a significant reduction in the nitrogen concentration of the shallow ground water originating in cultivated areas. Further studies of this problem have been proposed by Gilliam and Weed as a part of the research program of the Water Resources Research Institute of the University of North Carolina (David Howe11s, written commun., 1974). A broader study of the "water-quality ramification of converting forest to intensive agriculture" has also been proposed for joint Institute and Sea Grant funding by Barber and Kirby-Smith of the Duke University Marine Laboratory. This study, if funded, will concentrate on the Open Grounds Farm in Carteret County.

Studies of the quality of the runoff from the Albemarle-Pamlico region were started by the State Department of Natural and Economic Resources in June 1974 (Julian Taylor, oral commun., 1974). Samples are being collected periodically at four sites in the area. Analyses avai1able through December 31 are shown in table 5 .

First Colony Farms is also initiating a water-quality sampling program at eight sites on major canals draining farm areas (Steve Barnes, oral commun., 1974). 
Table 5.--Water-quality data collected by the North Carolina Department of Natural and Economic Resources in the Albemarle-Pamlico region

\begin{tabular}{|c|c|c|c|c|c|c|c|c|}
\hline \multirow{2}{*}{ Constituent or characteristic } & \multicolumn{3}{|c|}{ Site No. 1} & \multicolumn{2}{|c|}{ Site No. 2} & \multicolumn{2}{|c|}{ Site No. 3} & \multirow{2}{*}{$\frac{\text { Site No. } 4}{11 / 25 / 74}$} \\
\hline & $6 / 27 / 74$ & $8 / 29 / 74$ & $11 / 25 / 74$ & $6 / 27 / 74$ & $11 / 25 / 74$ & $8 / 29 / 74$ & $11 / 25 / 74$ & \\
\hline Ammonia as $\mathrm{N}(\mathrm{N})(\mathrm{mg} / 1) \ldots \ldots \ldots \ldots$ & 0.24 & 1.6 & 0.09 & 0.12 & 0.23 & 0.26 & 0.16 & 0.24 \\
\hline Kjeldah1 Nitrogen as $\mathrm{N}$ (N) (mg/1) ... & .7 & 1.1 & 1.3 & .3 & 1.4 & .9 & 1.7 & 1.6 \\
\hline Nitrate + Nitrate as $\mathrm{N}(\mathrm{N})(\mathrm{mg} / 1) \ldots$ & .28 & .06 & $<.05$ & .13 & .10 & .07 & $<.05$ & .07 \\
\hline Phosphorous (P) (mg/1), total (0)... & .25 & .06 & $<.05$ & .14 & .14 & .07 & .13 & .11 \\
\hline Phosphate, ortho $\left(\mathrm{PO}_{4}\right)(\mathrm{mg} / 1) \ldots \ldots$. & $<.05$ & & $<.05$ & $<.05$ & $<.05$ & $<.05$ & $<.05$ & $<.05$ \\
\hline Total residue................. & 240 & & 1,610 & 949 & 217 & & 762 & 361 \\
\hline Volatile (mg/1) ............ & 138 & & 320 & 278 & 97 & & 170 & 107 \\
\hline Fixed $(\mathrm{mg} / 1) \ldots \ldots \ldots \ldots \ldots$ & 102 & & 1,290 & 671 & 120 & & 592 & 254 \\
\hline Suspended residue $(\mathrm{mg} / 1) \ldots \ldots \ldots$ & 47 & 14 & 26 & 11 & 14 & 49 & 493 & 38 \\
\hline Volatile $(\mathrm{mg} / 1) \ldots \ldots \ldots \ldots \ldots$ & 21 & 10 & 22 & 3 & 2 & 6 & 87 & 10 \\
\hline Fixed $(m g / 1) \ldots \ldots \ldots \ldots \ldots$ & 26 & 4 & 4 & 8 & 12 & 43 & 406 & 28 \\
\hline Specific conductance (micromhos) ... & 99 & 100 & 2,100 & 1,450 & 120 & 70 & 125 & 330 \\
\hline $\mathrm{pH}$ (units) $\ldots \ldots \ldots \ldots \ldots \ldots \ldots \ldots$ & & 6.0 & & & & 5.9 & & \\
\hline BOD $(5-$ day $)(m g / 1) \ldots \ldots \ldots \ldots \ldots$ & 3.5 & 1.7 & 2.3 & 1.5 & 1.8 & 1.8 & 1.6 & 2.1 \\
\hline $\operatorname{COD}(\mathrm{mg} / 1) \ldots \ldots \ldots \ldots \ldots \ldots \ldots$ & 150 & & 100 & 120 & 91 & & 83 & 83 \\
\hline Total coliforms per $100 \mathrm{ml} \ldots \ldots \ldots$ & $>10,000$ & 5,000 & 710 & 6,000 & 3,200 & 45,000 & 900 & 180 \\
\hline
\end{tabular}

Location of sites:

1. Northwest Fork of Alligator River at N.C. Highway 94. (NER Site No. 12A)

2. Drainage canal tributary to Pungo River, $1 \mathrm{mi}$. NE of Ponzer. (NER Site No. 62A)

3. Drainage canal tributary to Scuppernong River, $1 \mathrm{mi}$. S. of Columbia. (NER Site No. 14-1A)

4. Basnight Canal at Frying Pan Landing. (NER Site No. 14-2A) 
The effect of pesticides in runoff from agricultural areas on the biological conditions in estuaries is of concern to marine biologists. study of the levels of organochlorine pesticides in mollusks from estuaries of 15 coastal States was started in 1965 by the U. S. Bureau of Commercial Fisheries. Responsibility for the work was transferred in 1971 to the U. S. Environmental Protection Agency. Of the 15 compounds searched for only three - DDT, DDE, and TDE - were found to be consistently present. In the North Carolina phase of the study, which was conducted under the direction of Dr. A. F. Chestnut of the University of North Carolina, Institute for Marine Sciences, oysters were collected from 18 sites, including three sites in the vicinity of the AlbermarlePamlico peninsula. The results show a marked decline in DDT and metabolites DDE and TDE beginning in 1969-1970, reflecting a drastic reduction in the use of DDT (Butler, 1973, p. 238). Data are not yet available to show whether other pesticides, including those used in place of DDT, are building up in the estuaries.

Runoff from recently cleared areas composed of mineral soils was observed in Apri1 1974 to contain a high concentration of suspended sediment (fig. 47). Sources of suspended sediment include both fields and drainage ditches and canals, except that very little suspended sediment originates in areas underlain by thick organic soils. No data are available on the amount of suspended sediment contained in the runoff from the region. Therefore, as was the case with runoff, it is necessary to utilize data from nearby areas. Figure 48 shows the sediment transport curve developed for Creeping Swamp at a site near Vanceboro on the Beaufort-Pitt County 1ine.

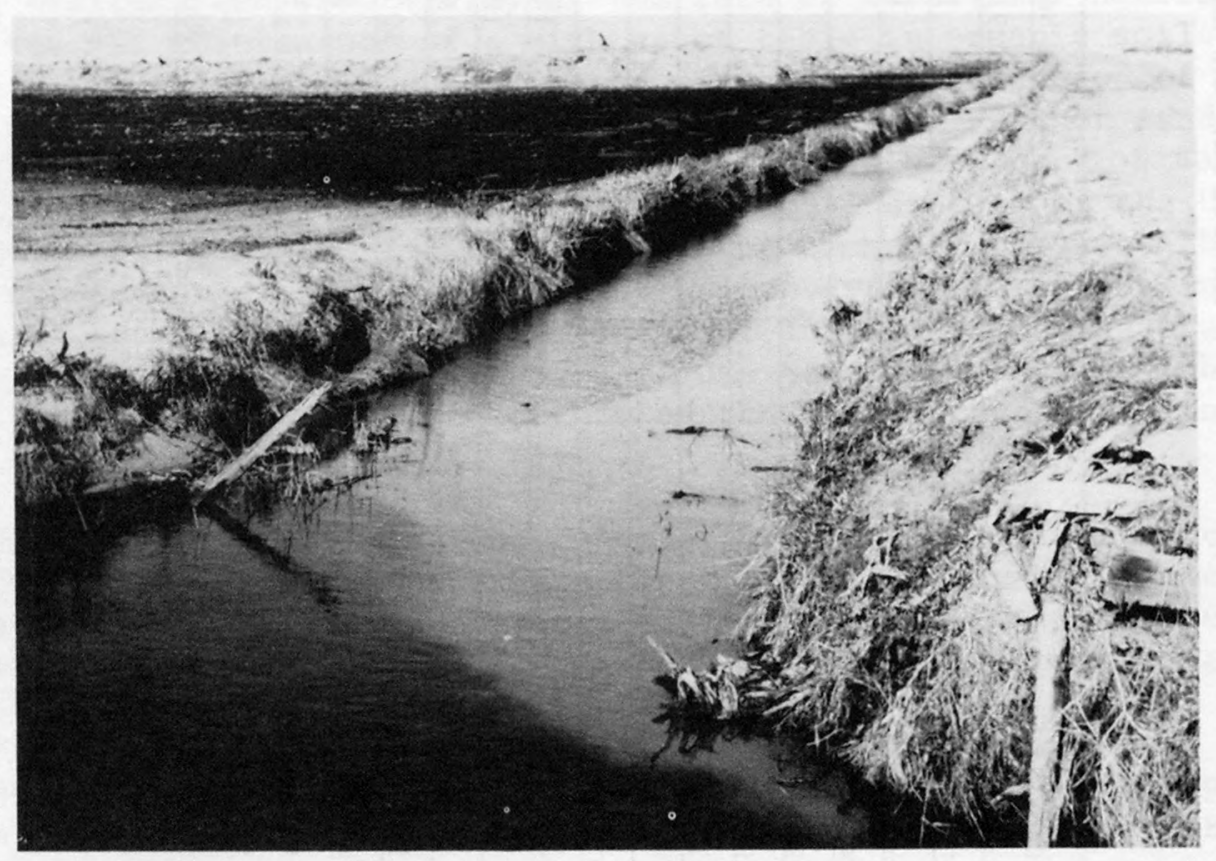

Figure 47.-- Drainage ditches in a newly cleared area during a wet period in Apri1 1974. Sediment-laden water in the ditch on the right is flowing under very dark colored, but less dense, water entering through the ditch at the left-hand side of the photograph. 


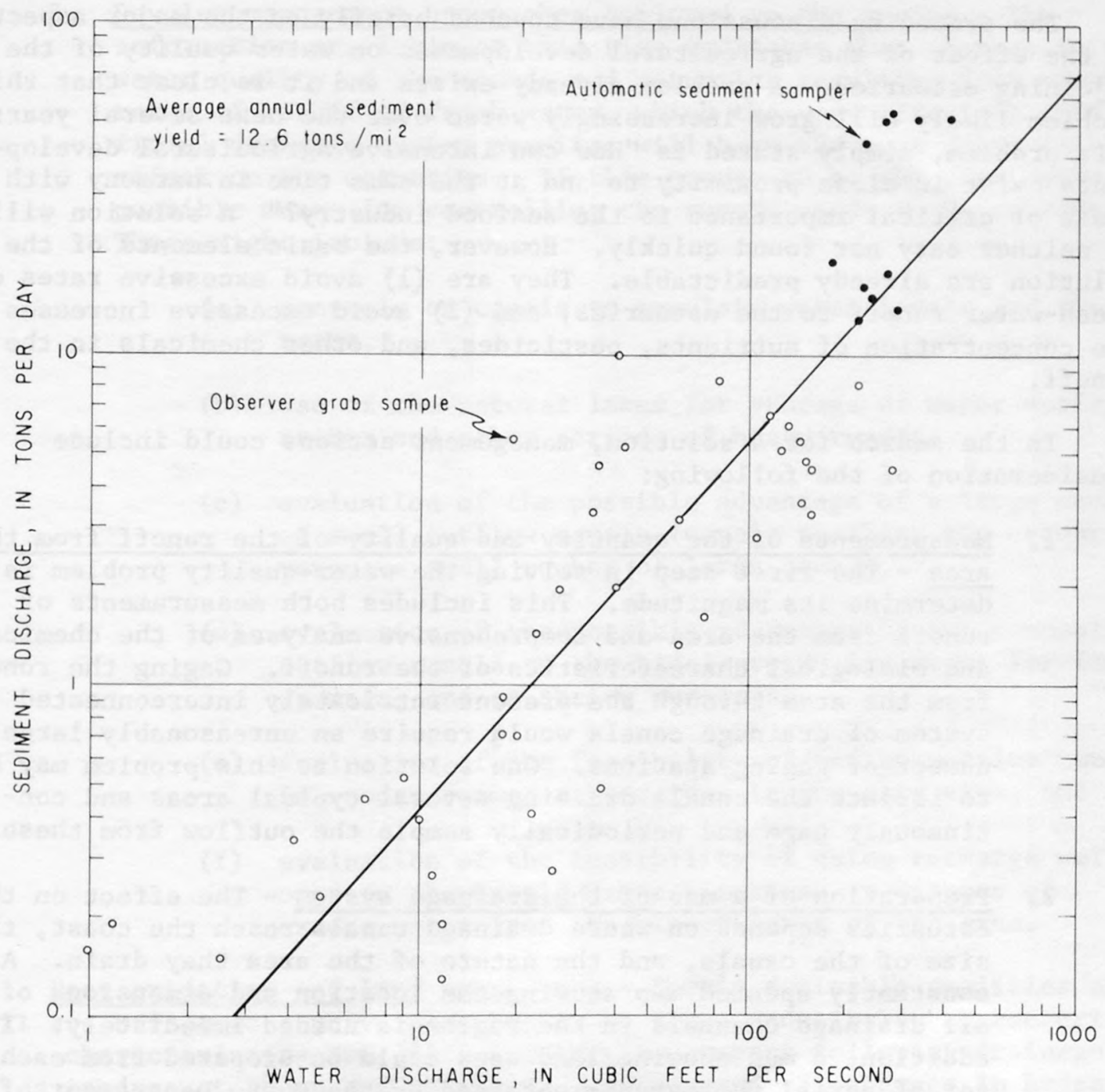

Figure 48. Relation between water discharge and sediment for Creeping Swamp near Vanceboro.

Most of the Creeping Swamp basin is still in forest and, although some field ditches have been dug to improve drainage, most stream channels are still in their natural state. As shown on figure 48, the average sediment discharge of Creeping Swamp is 12.6 tons per square mile per year. The amount of sediment derived from artificially-drained areas underlain by mineral soils in the Albemarle-Pamlico region is probably considerably more than this. However, when adjustment is made for the areas underlain by thick organic soils, the Creeping Swamp data may fairly closely represent conditions in the region. If this proves to be the case and we consider only the 1,000 square miles that may be under cultivation by 1980 , the suspended sediment reaching estuarine waters from the region at that time may amount to about 12,000 tons annually. Sediment has not previously been a problem in the area so the effect of sediment-laden runoff on the near-shore estuarine waters is not known. 
The preceding discussions have touched briefly on the major aspects of the effect of the agricultural developments on water quality of the adjoining estuaries. A problem already exists and it is clear that this problem likely will grow increasingly worse over the next several years. This problem, simply stated is "How can intensive agricultural developments exist in close proximity to and at the same time in harmony with areas of critical importance to the seafood industry?" A solution will be neither easy nor found quickly. However, the basic elements of the solution are already predictable. They are (1) avoid excessive rates of fresh-water runoff to the estuaries, and (2) avoid excessive increases in the concentration of nutrients, pesticides, and other chemicals in the runoff.

In the search for a solution, management actions could include consideration of the following:

1. Measurements of the quantity and quality of the runoff from the area - The first step in solving the water-quality problem is to determine its magnitude. This includes both measurements of runoff from the area and comprehensive analyses of the chemical and biological characteristics of the runoff. Gaging the runoff from the area through the present intricately interconnected system of drainage canals would require an unreasonably large number of gaging stations. One solution to this problem may be to isolate the canals draining several typical areas and continuously gage and periodically sample the outflow from these.

2. Preparation of a map of the drainage system - The effect on the estuaries depends on where drainage canals reach the coast, the size of the canals, and the nature of the area they drain. A constantly updated map showing the location and dimensions of a11 drainage channels in the region is needed immediately. In addition, a map showing land uses could be prepared from each set of aerial photographs obtained by the U. S. Department of Agriculture. These maps, used in conjunction with the drainage system map, will indicate the changing impact of the development on the estuaries and will be invaluable for both management and research.

3. Determine the impact of runoff on the fishery resources - In conjunction with item No. 1, an intensive study of the effect of the runoff from one or more of the gaged areas on the water quality and the biota of the estuary could be made.

4. Evaluate both water-management and crop-management practices on runoff - The water-management and crop-management practices adopted for use in the area could have two primary objectives; (1) to avoid excessive variations in runoff, and (2) to produce runoff containing the smallest possible concentrations of nutrients, pesticides, and other chemicals detrimental to marine 1ife. To accomplish these objectives, it would be desirable to initiate studies to test different water-management and cropmanagement practices. 
5. Develop management approaches tailored to the region - The information available at this time indicates that changes in the water quality of the sounds and estuaries resulting from excessive rates of runoff of fresh water, which the very efficient artificial drainage system permits, will have the most detrimental effect on the estuaries. If this proves to be the case every possible means for controlling the runoff needs to be considered. These might include:
(a) controls on canals to regulate water levels and flow
rates,
(b) use of the natural lakes for storage of water during storms and other periods of heavy runoff,
(c) evaluation of the possible advantage of a large number of small outflow canals (canals reaching the estuaries) versus a small number of large canals,
(d) evaluation of the possible advantage of not connecting outflow canals to the tidal creeks important for fish spawning and as shrimp nurserys,
(e) evaluation of the feasibility of ending outflow canals in wooded swamps rather than in the estuaries, and
(f) evaluation of the feasibility of using recharge wells open to the Castle Hayne Limestone to dispose of excess water from the higher parts of the area.

Peat oxidation and land subsidence - Peat's desirable qualities as a soil are offset to a very large degree by three undesirable characteristics. These characteristics are (1) a tendency to compact following drainage, (2) a tendency to burn and to slowly oxidize, and (3) changes in hydraulic properties resulting from oxidation. The long-term success of the agricultural developments on areas underlain by thick organic soils in the Albemarle-Pamlico region depends on success in avoiding or solving these problems.

The drainage of peat is followed immediately by compaction (shrinkage) resulting from drying and the loss of the buoyant force of the water (Stephens, 1969, p. 290). Dolman and Buo1 (1967, p. 41) in discussing the organic soils of the Tidewater area of North Carolina note that soil scientists assume an organic deposit will lose approximately one-third of its thickness upon drainage. Presumably the value of one-third refers to the depth through which the water table is lowered and not to the entire thickness of peat. 
The oxidation of peat results from its organic composition and may occur rapidly during fires or more slowly through biochemical action. The fire hazard in drained peat is an ever-present danger and, ance started, burning continues to the top of the saturated zone (Davis an Goodman, 1932, p. 19). Peat fires have occurred at numerous places in the region following drainage, including a 300-acre area north of Lake the lps that reportedly burned in 1973 when fire escaped from a windrow. Peat fires can be controlled by blocking the drainage ditches around the affected area and artificially raising the water table.

The slow oxidation of peat through biochemical action is cosiderably more difficult to control. Extensive studies of this problem have been conducted in the Florida Everglades by the Agricultural Research Service of the U. S. Department of Agriculture. These studies show that the rate of subsidence due to slow oxidation is dependent on the depth to the water table and ranges from 0.6 inch per year where the water table is maintained one foot below 1 and surface to 2.3 inches per year where table is three feet below 1and surface (Stephens, 1969, p. 292). D1mand Buol (1967, table 11) found that in an area west of Lake Phelps rinage alone had caused a decrease in peat thickness of 23 inches (from 67 inches to 44 inches). In a nearby area, as shown in figure 49, they found that compaction, fires, and slow oxidation had reduced the thickness of the peat by amounts ranging from 34 inches (34 percent) to 70 inches (10 perent). A study of land subsidence resulting from drainage in the studied by Dolman and Buol was started by the U. S. Soll Carvation Service in 1973 (Hubert Bird, oral commun., 1975).

Tree stumps and trunks occur throughout the peat rofile those parts of the region underlain by thick peat depoits. As the subsides, these are gradually uncovered and pose continusl clearing problem.

The third characteristic of peat mentioned earlier changes in its water-holding and water-transmitting properties ald is

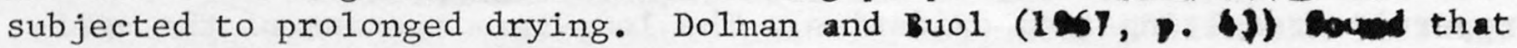
colloidal peats formed in areas that were wet for prolements which includes most of the region, are subject to a condition referm to as irreversible drying when not exposed to moisture for long periods. Co1loidal peat which has passed through this stage will neither aborb nor transmit water. As the peat dries at the surface it forms a hard crust which can be broken by plows into small pieces ("coffee grounds") which form a tillable layer. Wayne Skaggs of North Carolina State University is studying the drainage characteristics of an area underlain colloidal peat near the west side of Lake Phelps. He has found that therial is nearly impermeable when wet so that drainage throug fiel is is not an effective means of water-table control (Wayne skaes, 1 can., 1975). 


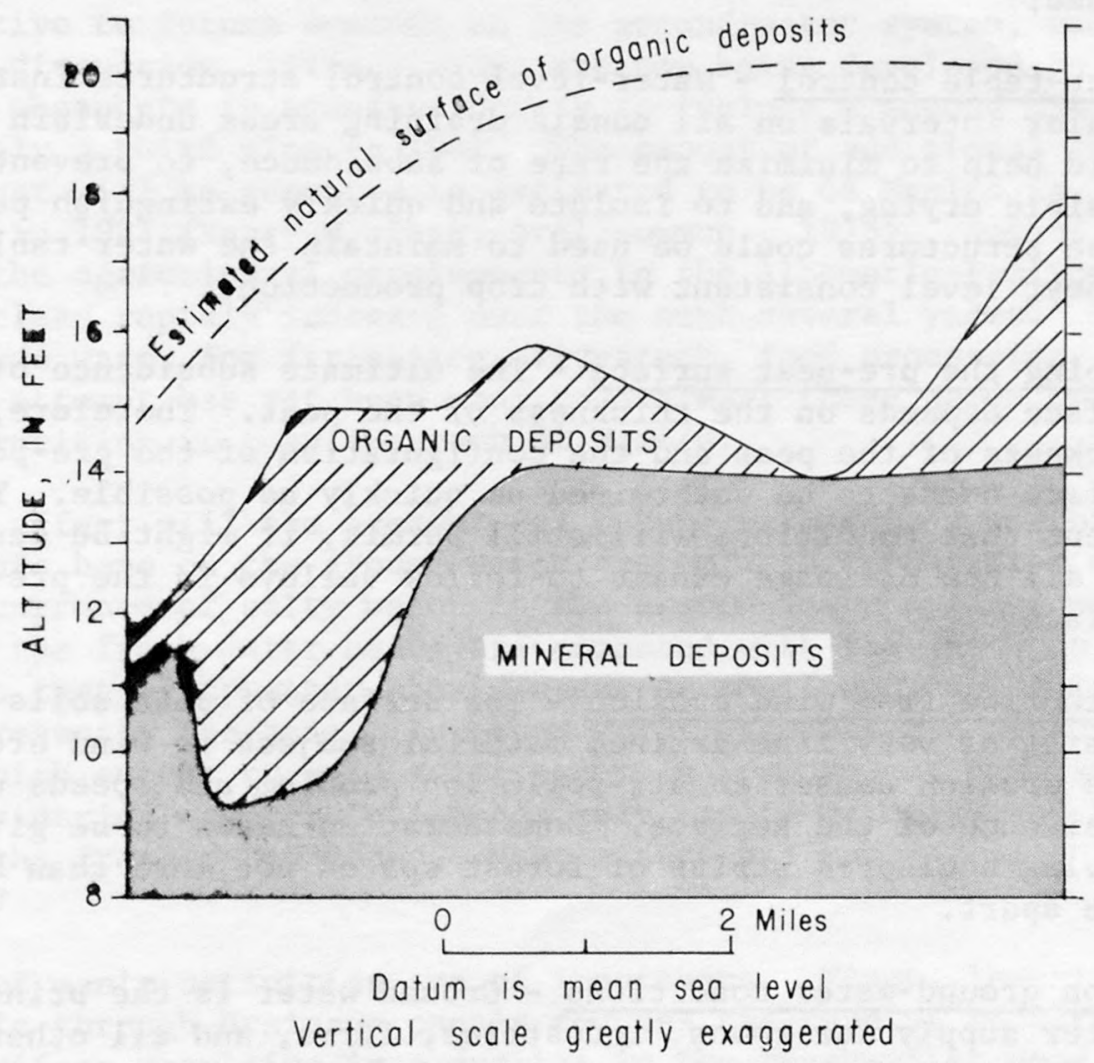

Figure 49.--Subsidence of the peat surface caused by drainage in an area west of Lake Phelps. (After Dolman and Buol, 1967, figure 4.)

Peat fires and irreversible drying can be prevented or readily controlled. If the water table is maintained at the highest level consistent ith optrum crop production, the rate of subsidence can be minimized but, as Stephens (1969, p. 303) notes, subsidence will still continue at undesirable rate. Problems which arise during the drainage and cultivation of peat areas prompted Davis and Goodman (1932, p. 19) to recommend "That the peat land, therefore, should be utilized for forests or for bird and game refuges." Because the subsidence of the peat depends on the depth to the water table, it is most rapid near drainage canals and ditches. To maintain adequate drainage it is necessary periodically to deepen the canals and ditches to keep pace with the subsidence. In time, the ditches and the fields reach the mineral subsoil (the prepeat surface). To quote Dolman and Buol (1967, p. 44) "In many parts of the Tidewater region the mineral subsoil is below sea leve1. Therefore, if the organic layer is removed by over drainage or fire extreme difficulties are anticipated." 
Development of the large areas in the Albemarle-Pamlico region underlain by peat pose important problems. Although the most serious aspect of these problems is not imminent, actions which need early consideration include:

1. Water-table control - Water-leve1 control structures installed at regular intervals on all canals draining areas underlain by peat would help to minimize the rate of subsidence, to prevent irreversible drying, and to isolate and quickly extinguish peat fires. These structures could be used to maintain the water table at the highest level consistent with crop production.

2. Mapping the pre-peat surface - The ultimate subsidence of the land surface depends on the thickness of the peat. Therefore, the thickness of the peat and the configuration of the pre-peat surface needs to be determined as quickly as possible. To the extent that conditions will still permit, it might be desirable for all new drainage canals to follow valleys in the pre-peat surface.

3. Protection from wind erosion - The surface of peat soils tends to consist of very fine-grained material subject to wind erosion. Such erosion causes an air-pollution problem and speeds up the subsidence of the surface. Consideration needs to be given to leaving uncleared strips of forest spaced not more than half a mile apart.

Effect on ground-water conditions - Ground water is the principal source of water supply for towns, industries, farms, and all other users in the region. Two other potential sources of fresh-water supplies are the lakes and the major drainage canals. All the lakes, except Lake Mattamuskeet, contain fresh water. Before this lake could be used for water supply it would be necessary to maintain its level continuously above sea leve1 and flush out the brackish water it now contains. Use of the drainage canals as a source of water supply is not now feasible because of their wide variations in flow. The development of a constant and dependable supply from canals would require the construction of reservoirs which, because of the flat terrain, is impractical. Use of water from the canals for domestic purposes might also pose a problem if the water contains appreciable amounts of agricultural chemicals. Therefore, for the foreseeable future the ground-water system will continue to be the primary source of water supply for the region.

The present use of ground water in the region is not large, amounting to about $1.5 \mathrm{Mgal} / \mathrm{d}$ from all aquifers. The ground-water system underlying the Albemarle-Pamlico peninsula is a small segment of the large Coastal Plain ground-water system. Therefore, it is not sufficient to consider only the effect of the withdrawals in the region on the local segment because this segment is also affected by withdrawals in other areas. These include withdrawals of about $60 \mathrm{Mgal} / \mathrm{d}$ at the phosphate mine in Beaufort 
County, industrial withdrawals near Plymouth of about $1 \mathrm{Mgal} / \mathrm{d}$, and industrial withdrawals at Washington of about $2 \mathrm{Mgal} / \mathrm{d}$. All of these large withdrawals are from the Castle Hayne Limestone.

Relative to future demands on the ground-water system, two items are worthy of discussion. First, plans are now being developed to expand the mining of phosphate in Beaufort County to include a second mine in 1977 and possibly a third mine in 1981. The amount of additional ground-water pumpage that will be required is estimated to be $44 \mathrm{Mgal} / \mathrm{d}$ in 1977 and $10 \mathrm{Mgal} / \mathrm{d}$ in 1981 (Harry M. Peek, oral commun., 1975). Second, the water needs of the agricultural developments in the Albemarle-Pamlico region will doubtless rapidly increase over the next several years. These needs will include water for irrigation, livestock, food processing, and other uses. No attempt has yet been made to estimate these needs but it would not be surprising if they approach $50 \mathrm{Mgal} / \mathrm{d}$.

What effect will the present and future withdrawals and other developments have on the ground-water system? In the earlier discussion of the occurrence of salty water in the ground-water system, we noted that when the fresh-water heads are compared with the depth to salty water, it appears that salty water should occur at shallower depths in the region than is presently the case. In other words, the natural fresh-water heads were not high enough to hold salty water in its present position. Therefore, considering natural influences only, salty water should be advancing into the fresh-water zones. What effect has man had on this situation?

Two of man's activities are of importance. First, lowering of the water table through drainage canals reduces the rate of recharge to the deeper aquifers resulting in a decline in the fresh-water head. Second, the withdrawal of water through wells tapping these aquifers causes a further decline in head. The effect of these declines is to accelerate the rate of salty-water encroachment. Lest this statement cause undue alarm, we need to consider what accelerate means in the sense it is used here.

In order for salty water to advance, it must first gain access to the deeper aquifers and then displace the fresh water. As shown in figure 15, the deeper aquifers dip towards the east so that there is an increasingly thicker section of sediments between the sea floor and the aquifers in an easterly direction. These sediments contain numerous clay beds which hamper the downward movement of sea water. Relative to the displacement of fresh water, it is difficult for most people to comprehend the large amount of water contained in saturated sediments and, therefore, the amount of water involved in salt-water encroachment. For example, the average depth to water containing $250 \mathrm{mg} / 1$ of chloride in the Albemarle-Pamlico region is about 170 feet. About 30 percent of the sediments above this depth consist of pores filled with fresh water. This amounts to a depth of fresh water of about 51 feet $(170 \times 0.30)$ over the 1,600 square miles of area or $17,000,000$ million gallons of fresh water. At a rate of use of $50 \mathrm{Mgal} / \mathrm{d}$ this volume of water would last 900 years. 
In other words, in terms of both man's withdrawals and salt-water encroachment, there is a very large volume of fresh water involved. However, this large volume does not mean that there is no problem; it simply means that the problem will not develop overnight.

The lowering of the artesian pressures in the Castle Hayne Limestone below sea level in a large area surrounding the phosphate mine in Beaufort County caused widespread concern in the late 1960's. The principal point of concern was whether this lowering would cause salt-water encroachment. Several studies related to this problem have been made including a joint comprehensive study by the staff of the State Ground Water Division and a group of consulting ground-water hydrologists, the results of which indicate that the encroachment of salty water over the next 100 years will be relatively minor (North Carolina Department of Water and Air Resources, 1971). Sherwani (1973) reanalyzed the data available on the Castle Hayne Limestone and reviewed and compared his results with those of all earlier studies. He concluded that salt-water encroachment might occur more rapidly than was indicated in the 1971 report, although the period of time involved was still several decades.

Because of the scarcity of data on the Castle Hayne aquifer, which is discussed in some detail by Sherwani, it has been necessary to assume that the confining beds in the Yorktown and overlying formations are continuous. Whether this proves to be the case depends on the depth of downcutting of stream channels during the period when sea level was below its present level. Streams such as the Pamlico River and its tributaries may have deepened their channels in the area affected by pumpage from the Castle Hayne and, in the process, removed a significant thickness of the confining beds. If so, the rate of downward leakage of brackish water from the estuary may depend on the character of the materials which now occur in the backfilled channels. For example, the tendency of the chloride concentration lines on figure 26 to parallel the Alligator and Pungo Rivers suggests the possible presence of discontinuities in confining beds in these areas.

During the course of his study of the geology and ground-water resources of the Swanquarter area, Nelson (1964) obtained data for the first time on the chemical quality of the ground water, including the chloride content, in wells throughout the Albemarle-Pamlico region. Since 1965, the State Division of Ground Water has periodically sampled wells throughout the area affected by pumpage at the phosphate mine. Because of the relatively short period of time for which records are available, none of them show evidence of salt-water encroachment, except in the immediate vicinity of the mine (North Carolina Groundwater Section, 1974, p. 57). With respect to monitoring salt-water encroachment, it is important to note that the State Groundwater Section (formerly the Division of Ground Water) has been engaged for several years in the construction of ground-water research stations which include wells screened in selected aquifers for both waterlevel observations and water-quality samples. Six stations are planned for the Albemarle-Pamlico region (North Carolina Groundwater Section, 1974, fig. 3). Stations south of Lake Mattamuskeet and west of Gum Neck are now 
under construction (Harry M. Peek, ora1 commun., 1975). The location of all these stations were selected to provide early warning of salt-water encroachment as well as data on regional declines in ground-water levels.

The preceding discussion has dealt with salt-water encroachment in the deeper aquifers, primarily the Castle Hayne Limestone. A more immediate problem may exist in the shallow aquifers, particularly the Quaternary deposits. The bottom of the drainage canals in eastern Tyrre11 County and in Dare and Hyde Counties are several feet below sea level and, as a result, offer an avenue for brackish water to move inland for considerable distances when rates of outflow are small. Some of these canals are now equipped with control structures and others will be so equipped in the future in order that canal levels can be maintained below sea level during the growing season. This may result not only in an upward movement of salty water from the deeper aquifers but also encourage brackish water to move inland through the shallow ground-water aquifer from the adjacent estuaries. In addition, all the canals reaching the coast provide avenues for brackish water to move inland during hurricanes and other major storms. In the past, storm inundation was minimized by the forests bordering the estuaries. The land clearing, if done too close to the estuaries, may aggravate this problem.

It is not possible to farm the Albemarle-Pamlico region without lowering the water table. It is also not feasible to mine and process the phosphate ore or to develop industries requiring good quality water without drawing water from the ground-water system. The problem from a water-management standpoint is to encourage uses of ground water which economically benefit the region while assuring that the available supply is not significantly reduced either in quantity or quality. To quote Sherwani (1973, p. 87): "It is hoped that in the Coastal Plain of North Carolina we are not condemned to repeat the history of many other areas in the nation going through the complete cycle of development of groundwater resource, overdevelopment, deterioration of water quality and attempted corrective measures."

It is difficult to develop effective policies for the management of ground-water systems before either the quantity or the quality of the water are significantly affected. Among the reasons for this is the great complexity of these systems which makes it extremely difficult to predict how and when they will respond to large withdrawals. Analog or digital models are the best predictive tools now available but, because of inadequate knowledge of most ground-water systems and the necessity of making certain simplifying assumptions in developing a model, the results obtained from them may be misleading and may foster a false sense of security. Also involved in this problem is the slow response of groundwater systems to stress, resulting from their large storage capacity which was mentioned earlier. This slow response also encourages complacency until damage has occurred. 
Conditions in the Albemarle-Pamlico region, both natural and manmade, are such that salty water will inevitably move into zones now containing fresh water. Whether this movement poses a problem in a hundred years or in a decade cannot now be determined. However, the importance of ground water to the future economy of the region suggests that long-range policies for the management of the ground-water system need to be considered. Although a critical situation does not now exist, it must be remembered that policies developed now may require decades to implement. In other words, as Sherwani suggests, North Carolina is still in a position in the region to profit from the mistakes of others.

Sherwani (1973, p. 87-99) has discussed the need for management of the ground-water system and some of the fundamental aspects involved in the development of management policies. Specific water-management policies applicable to the region are also discussed in the status report on groundwater conditions in the central Coastal Plain (North Carolina Groundwater Section, 1974, p. 80-91). The following list of items that might be considered in the development of water-management policies draws on both of these discussions.

1. Encourage withdrawa1s from the Castle Hayne aquifer in the southern part of Washington County - Analyses of the drawdowns caused by pumpage at the phosphate mine clearly show that the pumpage greatly increases recharge to the Castle Hayne Limestone, especially in the area where the confining beds are relatively thin. One of the beneficial effects of this increased recharge is to reduce the need for agricultural drainage. Therefore, large withdrawals from the Castle Hayne in the southern part of Washington County would not only provide water for municipal and industrial supplies but also aid agricultural development. Eastward from Washington County the Castle Hayne contains incrasingly salty water. The development of water supplies from the aquifer in this area ought to be discouraged.

2. Encourage artificial recharge of the Castle Hayne Limestone - To increase the availability of water from the Castle Hayne Limestone and, at the same time, reduce the rate of salt-water encroachment, every opportunity for artificial recharge needs to be explored. These could include disposal of excess water from Lake Phelps, New Lake, and Pungo Lake, as we11 as excess drainage from the higher agricultural areas. Cne means of disposing of excess water from agricultural areas, which is now being tested in De Soto County, Florida, consists of drilling wells to "connect" the water-table aquifer to deeper aquifers having lower heads. In this way farming is facilitated while the deeper aquifers are being recharged.

3. Avoid excessive surface drainage and pollution of shallow aquifers in recharge areas - Important recharge areas include a zone along the western boundary of the region where confining beds overlying the Castle Hayne Limestone are relatively thin. The northern part of Roanoke Island also appears to be the primary recharge area for the aquifer underlying the island and the adjoining mainland area. 
Because of the scarcity of fresh-water supplies in Dare County, this recharge area, as we11 as the recharge areas for the Castle Hayne Limestone, needs to be protected from pollution.

4. Expand geologic and hydrologic studies in the region - Because of the large anticipated water needs of the agricultural, mining, and other activities in the region and the important voids in knowledge of the ground-water system, the construction of groundwater research stations and the studies of the ground-water system need to be accelerated. In fact, only through such expansion will the information needed for effective management of the ground-water system be acquired.

\section{SUMMARY AND CONCLUSIONS}

Large parts of the Albemarle-Pamlico region are being converted from swamps to agricultural production. This conversion requires the construction of a dense network of drainage channels and may, in time, require large quantities of water for irrigation and other purposes. On the basis of the information now available, the most important problems that seem likely to result from the developments in the region, in their relative order of occurrence in time, are:

1. Changes in water quality of the sounds and estuaries resulting from the rapid runoff of storm waters containing dissolved material and bacteria harmful to the fishery resources.

2. Relatively rapid subsidence of the land surface in an irregular pattern in the extensive areas underlain by thick organic soils as a result of biochemical oxidation, peat fires, and wind storms.

3. Acceleration of salt-water encroachment in both shallow and deep aquifers as a result of land drainage and increased withdrawals of ground water for irrigation and other uses.

Although none of these problems can be completely avoided, some of their adverse effects can be significantly reduced by the application of presently available technology. The development and enforcement of sound policies can assure the application of this technology. The development of policies applicable to the region must be done with full realization of the economic benefits of the agricultural developments and of the fishery and other resources of the area to both the State and the Nation. Because it is not possible to protect any one resource without due consideration of the others, solutions to the problems will require cooperation of both public agencies and private interests. 
This report, as noted in the introduction, has been prepared almost entirely from existing information. This includes both information from published reports and information obtained in interviews with persons knowledgeable about the area. An attempt has been made in the text to identify the sources of all important information. However, the acknowledgments to information obtained orally are intended to give credit rather than to assign blame in case the information is misquoted.

Because of the references in the text, it is not necessary to repeat here the names of all the people who contributed to the preparation of the report. Several individuals, however, should be mentioned because the importance of their contributions is not otherwise obvious. Co1. Dan McDonald, assistant director of the State Division of Resource Planning and Evaluation, was instrumental in the initiation of the study and provided important background information. Harry M. Peek and his staff in the State Groundwater Section provided access to unpublished information and freely shared their personal knowledge of the geohydrology of the area. Robert Campbe11, First Colony Farms, provided soils maps of Tyrrell and Dare Counties and, together with Simon Rich and Steve Barnes, shared his extensive knowledge of the region.

Wayne Skaggs, North Carolina State University, provided information on his study of water-level control in areas underlain by peat. Mrs. Marjorie Lindsey of the North Carolina State Library aided in the search for information on early logging operations and canal construction in the region. 
The following factors may be used to convert the English units published herein to the International System of Units (SI).

Table 6.--Factors for converting English units to International System (SI) units

Multiply English units

\begin{tabular}{|c|c|}
\hline & Length \\
\hline $\begin{array}{l}\text { inches (m) } \\
\text { feet (ft) } \\
\text { miles (mi) }\end{array}$ & $\begin{aligned} 25.4 \\
.3048 \\
1.609\end{aligned}$ \\
\hline & Area \\
\hline $\begin{array}{l}\text { square feet }\left(f t^{2}\right) \\
\text { acres }\end{array}$ & $4047^{.0929}$ \\
\hline acres & $\begin{array}{l}.4047 \\
.4047 \\
.004047\end{array}$ \\
\hline square miles $\left(\mathrm{mi}^{2}\right)$ & 2.590 \\
\hline & Volume \\
\hline gallons (gal) & $\begin{array}{l}3.785 \\
3.785 \\
3.785 \times 10^{-3}\end{array}$ \\
\hline million gallons $\left(10^{6} \mathrm{gal}\right)$ & $\begin{array}{r}3785 \\
3.785 \times 10^{-3}\end{array}$ \\
\hline cubic feet $\left(\mathrm{ft}^{3}\right)$ & $\begin{array}{r}28.32 \\
.02832\end{array}$ \\
\hline & F1ow \\
\hline cubic feet per second $\left(f t^{3} / s\right)$ & 28.32 \\
\hline 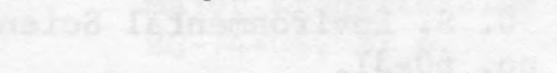 & $\begin{array}{l}28.32 \\
.02832\end{array}$ \\
\hline gallons per minute(gal/min) & .06309 \\
\hline & $6.309 \times 10^{-5}$ \\
\hline million gallons per day(Mgal/d) & $\begin{array}{l}43.81 \\
.04381\end{array}$ \\
\hline
\end{tabular}

To obtain SI units

\author{
millimetres (mm) \\ metres (m) \\ kilometres $(\mathrm{km})$
}

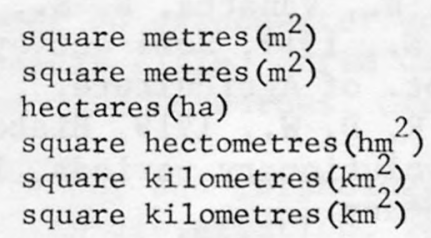

litres (1)

cubic decimetres $\left(\mathrm{dm}^{3}\right)$

cubic metres $\left(\mathrm{m}_{3}^{3}\right)$

cubic metres $\left(\mathrm{m}^{3}\right)$

cubic hectometres $\left(\mathrm{hm}^{3}\right)$

cubic decimetress $\left(\mathrm{dm}^{3}\right)$

cubic metres $\left(\mathrm{m}^{3}\right)$

litres per second( $1 / \mathrm{s})$

cubic decimetres per second $\left(\mathrm{dm}^{3} / \mathrm{s}\right)$

cubic metres per second $\left(\mathrm{m}^{3} / \mathrm{s}\right)$

litres per second( $1 / \mathrm{s})$

cubic decimetres per second $\left(\mathrm{dm}^{3} / \mathrm{s}\right)$

cubic metres per second $\left(\mathrm{m}^{3} / \mathrm{s}\right)$

cubic decimetres per second $\left(\mathrm{dm}^{3} / \mathrm{s}\right)$

cubic metres per second $\left(\mathrm{m}^{3} / \mathrm{s}\right)$ 
Asimov, Isaac, 1968, The intelligent man's guide to the biological sciences: New York, Washington Square Press, Inc., 402 p.

Brooks, C. E. P., 1970, Climate through the ages: New York, Dover Pub., Inc. (Republication of 1949 ed.), 395 p.

Brown, P. M., Miller, J. A., Swain, F. M., 1972, Structural and stratigraphic framework, and spatial distribution of permeability of the Atlantic Coastal Plain, North Carolina to New York: U. S. Geol。 Survey Prof. Paper 796, 79 p.

Butler, P. A., 1973, Organochlorine residues in estuarine mollusks, 1965-72, national pesticide monitoring program: Pesticides Monitoring Journal, v.6, no. 4, p. 238-362.

Cobb, W. B., and Davis, W. A., 1924, Soil survey of Tyrrell County, North Carolina: U. S. Dept. of Agriculture.

Cobb, W. B., Vanatta, E. S., Brinkley, L. L., Davidson, S. F., and McDowell, F. N., 1919, Soil survey of Beaufort County, North Carolina: U. S. Dept. of Agriculture.

Connor, R. D. W., 1919, History of North Carolina, v. 1, The colonial and revolutionary periods, 1584-1783: Chicago, The Lewis Publishing Company.

Davis, W. A., and Goodman, K. V., 1932, Soil Survey of Washington County, North Carolina: U. S. Dept. of Agriculture, ser. 1932, no。 8.

Dolman, J. D., and Buol, S. W., 1967, A study of organic soils (Histosols) in the Tidewater region of North Carolina: N. C. Agri. Expt. Sta. Bu11. no. 181,52 p.

Gambe11, A. Wo, and Fisher, D. W., 1966, Chemical composition of rainfa11, eastern North Carolina and southeastern Virginia: U. S. Geo1. Survey Water-Supp1y Paper 1535-K, $41 \mathrm{p}$ 。

Gambre11, R. P., Gilliam, J. W., and Weed, S. B., 1974, The fate of fertilizer nutrients as related to water quality in the North Carolina Coastal Plain: N. C. Water Resources Research Inst., rept. no. 93, $151 \mathrm{p}$.

Hardy, A. V., 1970, Climate of North Carolina: U. S. Environmental Science Services Adm., Climatography of the U. S. no. 60-31.

Haze1, J. E., 1975, Age and correlation of the Yorktown Formation (P1iocene) at the Lee Creek, North Carolina, phosphate mine: Smithsonian Contr. Paleobiology (in press)

Hobbie, J. E., 1974, Nutrients and eutrophication in the Pamlico River estuary, North Carolina, 1971-1973: N. C. Water Resources Research Inst., rept. no. 100,239 p.

Hughes, G. H., and McDonald, C. C. 1966, Determination of water use by phreatophytes and hydrophytes: Am. Soc. Civil Engr., Jour. Hydraulics Div., March 1966, p. 63-81.

Kaye, C. A., and Stuckey, G. W., 1973, Nodal tidal cycle of 18.6 yr.: Geology, v. 1, no. 3, p. 141-144.

Kimrey, Joel O., 1965, Description of the Pungo River Formation in Beaufort County, North Carolina: North Carolina Division of Mineral Resources Bu11. no. 79, 131 p. 
Lefler, H. T。, 1956, History of North Carolina, v. 1: New York, Lewis Historical Pub. Co., Inc., 466 p.

Lichtler, W. F., and Walker, P. N., 1974, Hydrology of the Dismal Swamp, Virginia-North Carolina: U. S. Geol. Survey, open-file rept. $74-39,50 \mathrm{p}$.

Milliman, J. D., and Emery, K. 0., 1968, Sea levels during the past 35,000 years: Science, v. 162, p. 1121-1123.

Mook, M. A., 1944, Algonkian ethnohistory of the Carolina Sound: Jour. Washington Acad. of Sci., v. 34, no. 6 (p. 181-197), no. 7 (p. 213-228).

Nelson, Perry F。, 1964, Geology and ground-water resources of the Swanquarter area, North Carolina: North Carolina Dept. of Water Resources, Ground-Water Bu11. 4, 79 p.

N. C. Dept. of Water and Air Resources, 1971, Summary of conclusions of report on hydrogeology and effects of pumping from Castle Hayne aquifer system, Beaufort County, North Carolina: Mimeographed report.

N. C. Groundwater Section, 1974, Status report on groundwater conditions in capacity use area no. 1, central Coastal P1ain, North Carolina: North Carolina Dept. of Natural and Economic Resources, Groundwater Bu11. no. $21,146 \mathrm{p}$ 。

Oaks, R. Q., Jr., 1965, Post-Miocene stratigraphy and morphology, outer Coastal Plain, southeastern Virginia: PhD dissertation, Yale Univ., 226 p. plus appendices. (Available from University Microfilms, Inc., Ann Arbor, Mich.).

Oaks, R. Q., Jr., and Coch, N. K., 1973, Post-Miocene stratigraphy and morphology, southeastern Virginia: Virginia Div. of Mineral Res. Bu11. 82, 135 p.

Peek, H. M., Register, L. A., and Nelson, P. F., 1972, Potential groundwater supplies for Roanoke Island and the Dare County beaches:

North Carolina Ground Water Div., Rept. of Inv. no. 9, 26 p.

Penman, H. L., 1963, Vegetation and hydrology: Commonwealth Bur. of Soils (Great Britain), Tech. Commun. no. 53.

Riggs, S. R。, and O'Connor, M. P., 1974, Relict sediment deposits in a major transgressive coastal system: Sea Grant Publication UNC SG-74-04, $37 \mathrm{p}$.

Rights, D. L., 1971, The American Indian in North Carolina: WinstonSalem, John F. Blair, 298 p.

Shaler, N. C., 1890, General account of the fresh-water morasses of the United States, with a description of the Dismal Swamp district of Virginia and North Carolina: U. S. Geol. Survey 10th Ann. Rept., pt. 1 , p. 255-339.

Sharpe, Bil1, 1965, A new geography of North Carolina, v. 4: Raleigh, Sharpe Publishing Company, p. 1681-2277. (Tyrrel1 County is described on p. 2121-2140.)

1966, A new geography of North Carolina, v. 2: Raleigh, Sharpe Publishing Company, p. 535-1114. (Hyde County is described on

p. 886-907.)

1966, A new geography of North Carolina, v. 3: Raleigh, Sharpe Publishing Company, p. 1115-1680. (Washington County is described on p. 1615-1640.) 
Sheridan, R. E., Dil1, C. E., Jr., and Kraft, J. C., 1974, Holocene sedimentary environment of the Atlantic inner shelf off Delaware: Geo1. Soc. of Am. Bu11., v. 85, no. 8, Aug. 1974, p. 1319-1328.

Sherwani, J. K., 1973, Computer simulation of ground-water aquifers of the Coastal Plain of North Carolina: North Carolina Water Resources Research Inst., rept. no. 75, 126 p.

Stephens, J. C., 1969, Peat and muck drainage problems: Am. Soc. Civil Engineers, Jour. Irrig. and Drainage Div., June, p. 285-305.

Vaughan, F. E., (compiler), 1884, The Albemarle section of North Carolina traversed by the Norfolk and Southern Railroad and its connecting steamboat lines: New York, John C. Rankin, Jr., printer, 80 p.

Ward, R. C., 1967, Principles of hydrology: London, McGraw-Hil1 Publishing Company, Ltd., 403 p.

Whitehead, D. R., 1972, Developmental and environmental history of the Dismal Swamp: Ecological Monographs, v. 42, no. 3, p. 301-315.

Williams, A. B., Posner, G. S., Woods, W. J., and Deubler, E. E., Jr., 1967, A hydrographic atlas of larger North Carolina sounds: U. S. Fish and Wildlife Service, Data Rept. 20, 130 p.

Yonts, W. L., Giese, G. L., and Hubbard, E. F., 1973, Evaporation from Lake Michie, North Carolina: U. S. Geo1. Survey, Water-Resources Inv. 38-73, $27 \mathrm{p}$.

Zeuner, F. E., 1952, Dating the past; an introduction to geochronology: London, Methuen and Company, Ltd., third ed., 495 p. 

U. S. DEPARTMENT OF THE INTERIOR Geological Survey

P. O. Box 2857

440 Century Sta. P. O. Bldg.

Raleigh, North Carolina 27602

POSTAGE AND FEES PAID
U.S. DEPARTMENT OF THE INTERIOR INT 413

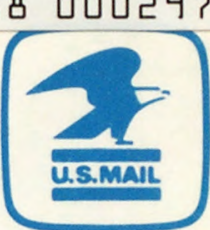

